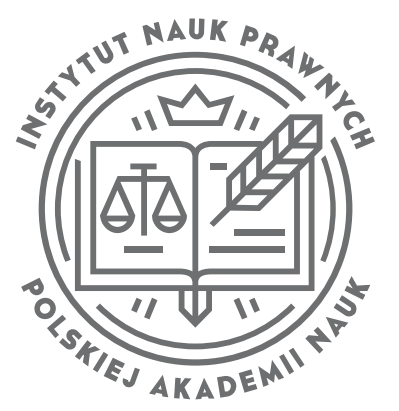

\author{
Dr Piotr Skorupa \\ Warszawa \\ piotr_skorupa@o2.pl
}

\title{
Nieważność czynności prawnej z perspektywy systemów prawnych common law
}

\begin{abstract}
Abstrakt
Artykuł opisuje złożoną problematykę nieważności czynności prawnej w jurysdykcjach common law. W ramach oceny najnowszych tendencji dotyczącej proporcjonalnego i nowoczesnego modelu normatywnego sankcji nieważności bezwzględnej szczególną uwagę zwraca się na ustawową sankcję sędziowską (structured discretion) zaproponowaną w związku $\mathrm{z}$ reformą instytucji illegality i immorality w prawie umów (i innych czynności prawnych).

Wpływ propozycji sankcji sędziowskiej na prawo polskie został ukazany na tle prac nad reformą sankcji illegality w niektórych krajach common law. Prace te wraz z bardzo cennymi materiałami zgromadzonymi w trakcie konsultacji miały także wpływ na kształt sankcji i jej proporcjonalizacji podczas opracowywania Common Frame of Reference. Przeanalizowano m.in. konieczne do poczynienia postępu w tej dziedzinie odejście od naturalistycznego postrzegania sankcji nieważności bezwzględnej w prawie prywatnym i rezygnacji z dogmatów wypracowanych jeszcze w czasach tzw. wielkich kodyfikacji XIX w. Dorobek nauki prawa i judykatury common law pokazuje jednoznacznie, że lakoniczna terminologia w normatywnych modelach sankcji nieważności bezwzględnej w kręgu ius civile wywarła negatywny wpływ na skuteczność i efektywność prawa.
\end{abstract}




\begin{abstract}
The article describes the complex institution of invalidity of juridical acts in common law jurisdictions. As a part of the assessment of the latest tendencies regarding proportional and modern normative model of such nullity, special attention is paid to the statutory sanctions (structured discretion) proposed to establish the legal effects of illegal and immoral contracts.

The impact of the sanctions on Polish law has been presented in the context of the reform of effects of illegality in some common law countries. These findings together with very valuable materials collected during the consultations process had also an impact on the shape of the sanction and its proportionality in the Common Frame of Reference. It was examined and analyzed that there is a need to move forward away from a naturalistic perception of invalidity in private law and to resign from the dogmas developed in the so-called the great codifications of the nineteenth century. The achievements of courts and jurisprudence in common law clearly showed that laconic terminology in normative models of absolute sanctions in the ius civile legal systems had very negative impact on the effectiveness and efficiency of the law.
\end{abstract}

\title{
$\S 1$. Wprowadzenie. Kryteria porównawcze
}

\subsection{Uwagi wstępne}

Podstawowym celem artykułu jest przybliżenie stanowiska systemów common law w zakresie stosowania środków prawnych, identyfikowanych w naszej tradycji prawnej pod nazwą „sankcja nieważności bezwzględnej”. Nieważność jako sankcja wadliwej czynności prawnej jest jedną z głównych instytucji prawa prywatnego. Zastosowanie tej sankcji łączy się bowiem $\mathrm{z}$ uniwersalnym problemem nieważności skutków prawnych, które miały nastąpić w związku z dokonaniem czynności prawnej. Rozwiązania common law, zwłaszcza dotyczące reakcji systemu prawa na przypadki najpoważniejszych wad czynności prawnej, którymi są niezgodność z przepisami prawnymi oraz niemoralność, nabierają szczególnego znaczenia w kontekście prac nad przyszłym polskim Kodeksem cywilnym i zmianami ustawowego modelu sankcji nieważności bezwzględnej.

Przedstawienie nieważności bezwzględnej w tradycji common law jest utrudnione, ponieważ ograniczona jest przydatność prostego stosowania kategorii pojęciowych wypracowanych w tradycji ius civile. Dotyczy to zarówno zagadnień formalnoprawnych i teoretycznych (np. pojęcie nieważności, definicja sankcji, rozumienie cech formalnych normy sankcjonującej, w tym proceduralnych 
zasad jej stosowania), jak też zagadnień materialnych ( $\mathrm{tj}$. podstaw stosowania nieważności z mocy prawa).

Ze względu na dość duże odrębności w stosunku do prawa polskiego celowe jest przyjęcie szeregu uproszczeń lub konwencji pojęciowych. Możliwe przy tym jest oparcie się na terminach wypracowanych przez dorobek tradycji ius civile, choćby o stereotypowych lub wręcz mylących zakresach znaczeniowych.

Kolejnym wyzwaniem jest wyjaśnienie charakterystyki instytucji prawnej o ogromnym znaczeniu praktycznym, którym jest sankcja stosowana w przypadku tzw. nielegalności lub niemoralności czynności prawnej. Widoczna jest tutaj duża różnica w stosunku do typowych rozwiązań systemów ius civile. W common law preferowane następstwa takich wad dotyczą istotnego zmodyfikowania cech formalnych normy sankcjonującej nieważnością bezwzględną, która powoduje brak albo istotne ograniczenie możliwości przywrócenia stanu poprzedniego. Dla ius civile prawo do restitutio in integrum jest reguła. Zachodzi zatem w common law pierwsza bardzo istotna różnica w koncepcji cech proceduralnych sankcji porównywalnej do kontynentalnej nieważności bezwzględnej (z mocy prawa) - wypracowana została odmiana szczególnej takiej sankcji, nazwana „niezaskarżalnością (unenforceable contract), powodująca wspomnianą utratę roszczeń kontraktowych, restytucyjnych (z bezpodstawnego wzbogacenia), a nawet deliktowych wynikających z danego stanu faktycznego.

Jedna z podstaw tej sankcji - zarzut niezgodności z ustawą lub porządkiem publicznym jest szczególnie szeroko stosowany, co często powoduje nieproporcjonalne rezultaty (np. w przypadku naruszenia przepisów o technicznym, publicznoprawnym lub pozbawionych znaczenia dla przedmiotu danej transakcji). W sytuacji jednostronnego (częściowego) wykonania umowy dla osoby nieświadomej nielegalności i pokrzywdzonej brakiem przywrócenia stanu poprzedniego $z$ reguły oznaczało to poniesienie nieproporcjonalnej straty na transakcji (w tym do znaczącej szkody z powodu utraty prawa własności wskutek niedopuszczalności przywrócenia stanu poprzedniego). Wynikało to z braku ochrony prawnej w systemie na roszczenia stron umowy (tzw. zasada braku interwencji sądu, wynikająca z sankcji opisowo nazwanej „niezaskarżalnością”). Utrwalało to status quo po częściowym lub całkowitym przeprowadzeniu transakcji wadliwej.

Stosowanie tak sztywnej, nieelastycznej i przez to nieproporcjonalnej sankcji dało asumpt do podjęcia prac legislacyjnych w niektórych krajach common law. W ich wyniku nastąpiło przyjęcie w kilku jurysdykcjach ustawowej podstawy do orzekania dyskrecjonalnego - delegującego na sędziego określenie sankcji wedle pewnego katalogu kryteriów, jeżeli naruszone przepisy nie regulują wyraźnie sankcji za ich naruszenie. Następnie regulacje te wywarły wpływ na stanowisko ius civile, w szczególności dzięki wykorzystaniu ich w pracach nad prawem modelowym w Unii Europejskiej. Doszło dzięki temu do zrobienia 
w europejskim prawie modelowym (The Principles of European Contract Law oraz Common Frame of Reference ${ }^{1}$ ) interesującej kariery przez specyficzną odmianę normy sankcjonującej określanej mianem structured discretion.

W 2015 r. (w zmienionym projekcie I Księgi Kodeksu cywilnego z 2009 r.) zaproponowano wprowadzenie istotnej zmiany w tradycyjnym sposobie sankcjonowania takich wad, którą oparto na dyskrecjonalnej, uporządkowanej sankcji sędziowskiej (structured discretion) ${ }^{2}$. Rozwiązanie to ma na celu wprowadzenie ustawowej podstawy do proporcjonalizacji stosowania nieważności z mocy prawa jako sankcji. Warto odnotować, że zasada proporcjonalności - adekwatnej i skutecznej reakcji na daną wadę - przyświecała inicjatywom legislacyjnym w kilku krajach common law. Niektóre z nich zostaną w najistotniejszych aspektach przedstawione $\mathrm{w}$ dalszych rozważaniach.

Wydaje się, że głównie pod wpływem rozwiązań DCFR w drugim projekcie I Księgi Kodeksu cywilnego z 2015 r. dokonano fundamentalnej zmiany podejścia do cech formalnych normy sankcjonującej stanem nieważności ipso iure (nieważności bezwzględnej) w obszarze regulacji następstw sprzeczności z prawem lub normami moralnymi. W ten pośredni sposób common law wywarło wpływ na prawo polskie w bardzo istotnej materii. Koncepcja structured discretion zostanie poniżej przybliżona dla wyjaśnienia przyczyn jej zaadaptowania przez common law w omawianym obszarze prawa prywatnego.

\subsection{Założenia terminologiczne. Uwagi na temat definicji stanu nieważności i sankcji nieważności bezwzględnej}

Najdalej idącym problemem, rzutującym istotnie na zakres niniejszego artykułu jest zdefiniowanie pojęcia sankcji nieważności z mocy prawa (bezwzględnej) w zestawieniu z innymi normami sankcjonującymi powodującymi stan nieważności, a następnie wykorzystanie tej aparatury pojęciowej w przedstawieniu

1 Następnie unormowanie The Principles of European Contract Law wykorzystano w dużej mierze w UNIDROIT Principles of International Commercial Contracts (PICC). W UPICC z 1994 i 2004 r. brakowało pełnej regulacji nieważności bezwzględnej. Skutki prawne nielegalności i niemoralności umów oraz koncepcja sankcji została wdrożona przy okazji trzeciej edycji ww. reguł w 2010 r. Obecnie powtórzono ją w edycji PICC z 2016 r. W zasadach z 1994 i 2004 r. jedynie w art. 6.1.17 PICC przewidziano sankcję nieważności bezwzględnej umowy, całkowitą lub częściową, w przypadku braku zgody na zawarcie umowy lub jej wykonanie (art. 6.1.14 PICC). W 3 edycji Principles Of International Commercial Contracts w maju 2008 r. (oraz w wersji gruntownie poprawionej w maju 2009 r.) opublikowano projekt rozdziału o nielegalności i niemoralności umów. Z niewielkimi zmianami powtórzony został w edycji z $2016 \mathrm{r}$.

2 Por. szerzej R. Trzaskowski [w: ] Kodeks cywilny. Księga I. Część ogólna. Projekt Komisji Kodyfikacyjnej Prawa Cywilnego przyjęty w 2015 r. z objaśnieniami opracowanymi przez członków zespotu problemowego KKPC, pod red. P. Machnikowskiego, Warszawa 2017, s. 104 i nn. 
ogólnych założeń nieważności w common law. Problem dotyka common law w porównywalnym stopniu co np. naukę polską, gdzie wiele sporów prowadzonych jest o zakresy znaczeniowe i wzajemne relacje terminów: nieważny, bezskuteczny, wadliwy albo o cechy nieważności i jej proceduralne stosowanie. W nauce zwraca się trafnie uwagę, że najdrobniejsze uproszczenia i przesunięcia w typologii wadliwych czynności prawnych mogą być brzemienne w swych następstwach ${ }^{3}$.

Zakres znaczeniowy słowa „nieważność”, co empirycznie potwierdza przegląd wypowiedzi doktryny i orzecznictwa większości jurysdykcji ius civile i common law, najczęściej stosowany jest w znaczeniu naturalnym. W modelach normatywnych wielu jurysdykcji brakuje pełnej regulacji cech formalnych tej normy sankcjonującej, a zwłaszcza ustawowej definicji, jak rozumieć sankcję nieważności od strony jej cech formalnych (tj. bezwzględną, względną, zawieszoną), tj. nie określa się proceduralnych cech formalnych normy sankcjonującej. Oddaje się wówczas inicjatywę judykaturze i jurysprudencji. Niestety, nie wzmacnia to efektywności systemu prawa, ponieważ interpretacja nieważności w prawie prywatnym najczęściej opiera się na naturalistycznym postrzeganiu nieważności jako instytucji prawnej zdefiniowanej przez same podwaliny systemu prawa prywatnego; jako bytu niemal ontologicznego.

W aktualnym prawie polskim przepisy nie zawierają określenia „nieważność bezwzględna"4; najczęściej zawierają termin nieważność, a bardzo sporadycznie „nieważność z mocy ustawy”. Problemem w takim przypadku jest ocena, czy mamy do czynienia z nieważnością jako następstwem zastosowania innych sankcji (np. bezskuteczności zawieszonej), czy jest to sankcja stanu nieważności (braku) skutków prawnych ex lege. Dotykamy tutaj bardzo istotnego problemu prawa prywatnego - dwupoziomowego znaczenia terminu nieważności. W największym skrócie wyjaśniając to stwierdzenie, należy przede wszystkim wskazać, że z punktu widzenia następstw zastosowania danej sankcji wadliwości, to stan, w którym czynność prawna nie wywiera zamierzonych skutków prawnych, jest ostatecznym wynikiem zastosowania każdej z sankcji „wadliwości”. Poszczególne odmiany takich norm sankcjonujących to środki prawne, których stosowanie eliminuje $z$ obrotu skutki prawne oświadczenia woli (czynności prawnej) w określonej procedurze opartej na kompetencjach podmiotów chronionych albo norma sankcjonująca działa z mocy samego prawa ${ }^{5}$.

3 Por. szerzej, wraz z dalszym piśmiennictwem i judykaturą, M. Gutowski, Nieważność czynności prawnej, wyd. 4, Warszawa 2017, s. 39 i nn.

4 Niektóre kodyfikacje stosują inne podejście do definicji, np. Kodeks Napoleona po reformie z 2016 r., Kodeks cywilny kanadyjskiej prowincji Québec, Kodeks cywilny stanu Luizjana.

5 Por. A. Bierć, Zarys prawa prywatnego. Część ogólna, Warszawa 2012, s. 438-439, P. Skorupa, Normatywne modele sankcji nieważności bezwzględnej, a nieistniejąca czynność prawna, „Studia Prawnicze” 2010, z. 1, s. 33-37. 
Wydaje się w konkluzji, że raczej pewnym utartym sposobem mówienia i tradycją, która ugruntowana jest obecną terminologią kodeksową, jest wyodrębnienie innych - od sankcji nieważności bezwzględnej - odmian środków ochrony prawnej jako „sankcji” ${ }^{\circ}$, a nie przepisów kompetencyjnych opisujących proceduralne ułożenie praw i obowiązków uczestników czynności prawnej dotyczące jej wzruszenia, potwierdzenia lub nawet względnej bezskuteczności (por. art. 59 kc). Zrozumienie tła sporów wynikających z niedookreślonych zakresów znaczeniowych terminów niezbędne jest dla oceny sposobu tworzenia normatywnych modeli normy sankcjonującej nieważnością ex lege. W tym ostatnim zdaniu kryje się założenie de lege ferenda - model norm sankcjonujących brakiem (nieważnością) zamierzonych skutków prawnych powinien mieć w sposób ustawowy (obok terminologii i definicji) uregulowany zespół cech formalnych nieważności jako normy sankcjonującej. Innymi słowy, ustawa powinna wskazywać cechy formalne normy sankcjonującej, które są emanacją celu tej sankcji. Chodzi o wykluczenie skutków prawnych, jakich nie zamierza ustawodawca tolerować $\mathrm{w}$ systemie prawa $\mathrm{z}$ powodów określonej polityki. Wykluczenie to powinno nastąpić w przypadku wad najpoważniejszych w sposób szybki i skuteczny - ex lege - oraz proporcjonalny do danego naruszenia. W konsekwencji, w tym dla uniknięcia nieco pretensjonalnego odrzucenia utrwalonych tradycji terminologicznych, można zaaprobować stosowanie słowa „bezwzględna” w odniesieniu do omawianej sankcji ${ }^{7}$. Podejście to zastosowano, np. w prawie francuskim, definiując nieważność absolutną i relatywną w ramach reformy z 2016 r. Z tym zagadnieniem łączy się kolejny problem kształt normatywnej definicji nieważności bezwzględnej.

\subsection{Definicja nieważności bezwzględnej jako normy sankcjonującej ex lege stanem nieważności skutków prawnych}

Definiowanie nieważności nie jest w zasadzie możliwe bez uprzedniego wytyczenia założeń konwencjonalnych i teoretycznoprawnych. Dla potrzeb takiej

6 Por. odmienne i krytyczne stanowisko R. Trzaskowskiego - R. Trzaskowski, Skutki sprzeczności umów obligacyjnych $\mathrm{z}$ prawem. W poszukiwaniu sankcji skutecznych i proporcjonalnych, Warszawa 2013, s. 258.

7 W sprawie stanu nieważności - braku skutków prawnych - wynikającego z innych norm sankcjonujących, np. wzruszalności lub bezskuteczności zawieszonej, można sformułować generalną uwagę, że powstaje on w razie zaistnienia zdarzeń dodatkowych (np. oświadczenia o uchyleniu się od skutków prawnych, odmowy potwierdzenia czynności prawnej podjętej $\mathrm{z}$ przekroczeniem pełnomocnictwa). Stanowisko to nie jest prezentowane w nauce. Dominuje pryzmat badawczy, który objaśnia sens wadliwych czynności prawnych z wykorzystaniem podejścia ontologicznego, praktycznego, w tym z powołaniem się na dorobek teorii czynności konwencjonalnych - por. w tym ostatnim przypadku zamiast wielu M. Gutowski, Bezskuteczność czynności prawnej; Tenże, Wzruszalność czynności prawnej, Warszawa 2010, s. 8 i nn. 
definicji należy rozstrzygnąć uprzednio zakres pojęciowy terminu sankcja i przedmiot sankcji, sposób zastosowania sankcji: cechy proceduralne (formalne cechy normy sankcjonującej sprzężonej z normami merytorycznymi), następstwo zastosowania sankcji, czyli sposób oddziaływania względem nieakceptowalnych skutków prawnych.

Definicja jest, jak głosi znana paremia, źródłem zagrożenia błędem. Można spróbować takie ryzyko mitygować poprzez definicję nieważności bezwzględnej wyłącznie w ujęciu konwencjonalnym. Kluczową kwestią jest przesądzenie, że na mocy normy sankcjonującej z danym zachowaniem prawo nie łączy żadnych, w tym również tzw. zamierzonych, skutków prawnych przez składającego oświadczenie woli; oraz że efekt ten występuje w ściśle określonym trybie. Jest to zagadnienie najważniejsze dla zapewnienia efektywności prawa - system prawny eliminacje (czyli „nieważność”) skutków prawnych realizuje poprzez system reguł opisujących procedurę (tryb) ich usunięcia lub zablokowania możliwości ich powstania.

Ilustracją możliwych sposobów definiowania jest wskazanie, że od strony techniki legislacyjnej model normatywny może być oparty na podejściu opisowym albo na rozwiązaniu odmiennym - podejściu syntetycznym. Zdanie opisowe może brzmieć: działanie sprzeczne $z$ norma $X$ nie wywiera od początku żadnych skutków prawnych zamierzonych przez podmiot $P$ lub nie wywiera skutków prawnych ustawowo do tego dziatania „przypisywalnych" (art. $56 \mathrm{kc}$ ), a brak skutków prawnych nie wymaga sądowego potwierdzenia $i$ każdy podmiot może powotać się, w każdym czasie, na fakt catkowitego braku skutków prawnych $z$ mocy prawa. $\mathrm{W}$ regulacji kodeksowej może to zostać zamienione na zdanie syntetyczne: „czynność prawna sprzeczna $z$ norma X jest nieważna”.

W przypadku takiej lakonicznej, choć eleganckiej, jednozdaniowej regulacji (por. art. $58 \mathrm{kc}$ lub $§ 134$ niemieckiego Kodeksu cywilnego), jeżeli nie jest normatywnie sprecyzowana kwestia, jak owa „nieważność” operacyjnie ma wystąpić, pojawia się oczywista i natychmiastowa możliwość zaistnienia sporów opartych na wieloznaczności słowa „nieważność”. Historia wielu kodyfikacji dostarcza twardych dowodów empirycznych, że nauka prawa i orzecznictwo nie są odporne na naturalne - ontologiczne konotacje terminu „nieważność. Najczęściej proponuje się modyfikację trybu wystąpienia nieważności w celu unikania automatyzmu nieważności z mocy prawa - czyli zmienia się cechy formalne sankcji, to zaś wywołuje różnego rodzaju spory.

Odnośnie do określenia cech normy sankcjonującej uzasadniony wydaje się wniosek, że na gruncie podejścia proceduralnego definiuje to system prawa. W odmiennym przypadku konieczne byłoby przyjęcie założenia o istnieniu i prymacie ontologicznego rozumienia nieważności. Wówczas należałoby zaakceptować nieważność jako instytucję prawną narzuconą przez prawo naturalne. Można to określić „ontologizacją” sankcji nieważności 
bezwzględnej: zamiast podejścia normatywnego do istoty tej normy sankcjonującej, której stosowanie oparte jest na potrzebach kreowanych polityką prawa. Tym samym narzuca się „naturalne” cechy sankcji nieważności bezwzględnej ${ }^{8}$. Powoduje to wzrost nieprzewidywalności i rozbieżności rozstrzygnięć sądów.

$\mathrm{Na}$ zakończenie uwag wprowadzających, należy odnieść się do pojęcia sankcji. Termin ten w kontekście sankcji nieważności jest wynikiem przyjęcia dużej umowności i utrwalenia się tego określenia w znaczeniu istotnie odległym od przypisywanego temu terminowi ${ }^{9}$. Kontynuując tę myśl należy przyjąć za E. Łętowską, że „wielość typów sankcji (rozumianej jako uchybienie jakiemuś obowiązkowi) jest charakterystyczną cechą prawa cywilnego. To powoduje, że posługiwanie się uogólnionym pojęciem «sankcji w prawie cywilnym» jest mało przydatne i nieoperatywne" 10 .

Wydaje się, że najtrafniejszym ujęciem pojęcia „sankcja” w kontekście nieważności bezwzględnej jest zaakceptowanie, że to termin mylący; nieadekwatny do potrzeb cywilistyki $\mathrm{i}^{11}$. Jego zaś stosowanie ma walor o tyle przydatny, jeżeli pamięta się, że prawidłowo powinno się ujmować następstwa wadliwości czynności prawnej od strony stosowania norm sankcjonujących. Norma sankcjonująca z punktu widzenia prawa efektywnego powinna być postrzegana wyłącznie jako byt konwencjonalny: dzięki czemu możemy odrzucić znaczenia stereotypowe, spory o słowa i szkodliwą ontologizację ${ }^{12}$.

Zgodnie z poprzednimi uwagami tok dalszych rozważań będzie oparty na łącznym przedstawieniu zagadnień formalnych (cechy formalne normy

8 W ostatnich latach w nauce polskiej nastąpił istotny zwrot w tradycyjnym rozumieniu terminologii kodeksowej dotyczącej nieważności - por. zamiast wielu R. Trzaskowski, Skutki sprzeczności umów obligacyjnych..., s. 790 i nn. Autor m.in. krytycznie ocenia propozycję uznania stanu nieważności za sankcję właściwą, gdzie instytucje - takie, jak: sankcja nieważności bezwzględnej, nieważności względnej, bezskuteczności zawieszonej lub bezskuteczności względnej-normują jak i czy w ogóle dojdzie do stanu nieważności skutków prawnych - Tamże, s. 257-259.

9 Por. szerzej M. Wincenciak, Sankcje w prawie administracyjnym i procedura ich wymierzania, Warszawa 2008, s. 40-41.

10 E. Łętowska, Sankcje w prawie cywilnym - zarys problemu, „Monitor Prawniczy” 2013, nr 19, s. 1015.

11 Tamże, s. 1015-1016.

12 W sprawie rozumienia pojęcia „sankcja” - por. zamiast wielu tamże, passim. Należy przywołać jedną z wielu trafnych wypowiedzi autorki o znaczeniu pierwszorzędnym dla nauki o nieważności czynności prawnej: wielość typów sankcji (rozumianej jako uchybienie jakiemuś obowiazkowi) jest charakterystyczna cecha prawa cywilnego. To powoduje, że postugiwanie się uogólnionym pojęciem „sankcji w prawie cywilnym” jest (...) nieoperatywne. (...) Uogólnionego pojęcia sankcji w prawie cywilnym po prostu brak; por. także A. Stelmachowski, Zarys teorii prawa cywilnego, Warszawa 1998, s. 212-213 
sankcjonującej) oraz materialnych (merytoryczne normy sankcjonowane, tzn. podstawy nieważności z mocy prawa $)^{13}$.

Powyższa problematyka i konieczność poszukiwania proporcjonalności w stosowaniu sankcji nieważności bezwzględnej (lub analogicznych instrumentów prawnych) dotyka także jurysdykcje common law. Koncepcja nieważności czynności prawnej jest uzupełniona i wręcz zastąpiona w znacznej mierze doktryną illegality oraz wypracowaniem innej normy sankcjonującej - wspomnianej sankcji niezaskarżalności. Wynikają z tego interesujące wnioski dla prawa kontynentalnego oraz problemy praktyczne głównie związane z rozciągnięciem zasięgu tej sankcji na utratę roszczeń o przywrócenie stanu poprzedniego.

\section{$\S 2$. Terminologia i cechy formalne nieważności jako normy sankcjonującej w systemach tradycji prawnej common law}

\subsection{Rodzaje sankcji nieważności}

Dalsze rozważania będą się odnosić głównie do prawa umów. Tradycja common law prezentuje mniejsze przywiązanie do abstrakcyjnych pojęć jak czynność prawna. Nieważność bezwzględną w takiej sytuacji należy przedstawić na tle prawa umów. Powszechnie wyróżnia się trzy odmiany wadliwych umów: umowy nieważne (void), wzruszalne (voidable) oraz nieegzekwowalne, niezaskarżalne (unenforceable), gdzie każda $\mathrm{z}$ wad jest sankcjonowana stanem nieważności skutków prawnych po zastosowaniu określonej procedury przez uprawniony podmiot albo z mocy prawa ${ }^{14}$. Innymi słowy sankcje te informują o różnych stopniach nieskuteczności (bezskuteczności) umowy ${ }^{15}$.

Od strony źródeł wadliwości powszechnie wyróżnia się następujące odmiany nieważności lub sankcji unenforceable:

- umowy nieważne z mocy ustawy (contracts declared void by statute);

- umowy nielegalne z mocy ustawy (contracts declared illegal by statute);

- umowy nieważne w prawie powszechnym (contracts void at common law);

13 W kwestii porównań na poziomie stosowania prawa por. także w polskim piśmiennictwie - W. Jarosiński, Wptyw stosowania normy pretorskiej na treść zobowiązan w prawie polskim i angielskim, „Transformacje Prawa Prywatnego” 2011, nr 1, s. 36 i nn.

14 Chitty on Contracts, General Principles, vol. 1, pod red. H.G. Beale'a, wyd. 31, London 2014, s. 80-81.

15 W nauce podkreśla się, że do tych trzech zasadniczych terminów w praktyce stosowana jest także inna terminologia - por. szerzej J.A. Schaefer, Beyond a Definition: Understanding the Nature of Void and Voidable Contracts, „Campbell Law Review Review” 2010, vol. 33, s. 193. 
- umowy nielegalne w prawie powszechnym (contracts illegal at common law $)^{16}$.

Podziały powyższe wymagają oceny ich następstw praktycznych, stąd w dalszych rozważaniach podjęta będzie próba wskazania czynników najmocniej rzutujących na odrębności w formalnych (proceduralnych) cechach norm sankcjonujących.

Porównanie podejścia systemów common law do nieważności umów (i innych czynności prawnych) w prawie kontynentalnym, w tym polskim, niezbędnym czyni uwzględnienie następujących kwestii i problemów:

- odmiennej konstrukcji systemu common law w zakresie innych relacji norm prawa materialnego i procesowego. W ius civile gwarancją wymiaru sprawiedliwości są normy prawa materialnego, a celem norm procesowych jest, co do zasady, jedynie wprowadzenie norm prawa materialnego w życie ${ }^{17}$,

- wywodzenie się prawa umów z prawa formalnego: oparcie jego rozwoju na ewolucji skargi (rytu) o zwrot długu i brak wpływu pojęcia oświadczenia woli (a tym samym czynności prawnej) na powstanie prawa do ww. skargi o zwrotu długu ${ }^{18}$,

- ochrona powagi sądów i wynikający z tego zakaz przyznawania skargi z umów naruszających ustawy i moralność (pochodzenie pewnych następstw sankcji unenforceable),

- brak roszczeń restytucyjnych oraz o zwrot bezpodstawnego wzbogacenia w przypadku najpoważniejszych rodzajów wadliwości (np. nielegalności, niemoralności lub naruszenia porządku publicznego),

- brak wyodrębnionej gradacji stopnia naruszeń ustaw na mniej lub bardziej istotne w kontekście stosowania sankcji niezaskarżalności.

W nauce podkreśla się, że common law nie jest wolne od sprzeczności w traktowaniu języka ustawy odwołującego się do terminu nieważności jako sankcji. W takiej sytuacji często przyjmuje się zarówno sankcję nieważności bezwzględnej, jak też względnej nieważności ${ }^{19}$. Przypomina to np. problemy z typologią sankcji w prawie polskim. Warte odnotowania jest, że jeżeli nie mamy

16 Ch. Turner, Key Facts Key Cases, Contract Law, Abingdon 2014, s. 176.

17 Por. w szczególności wraz z dalszym piśmiennictwem J. Halberda, Historia angielskich quasi-kontraktów a zasada bezpodstawnego wzbogacenia, „Państwo i Prawo” 2012, nr 1, s. 65.

18 Por. szerzej, wraz z dalszym piśmiennictwem, m.in. D. Kennedy, From the Will Theory to the Principle of Private Autonomy: Lon Fuller's Consideration and Form, „Columbia Law Review” 2000, vol. 100, iss. 1, s. 141, 102. W kwestii historii common law - por. szerzej wraz z dalszym piśmiennictwem J. Halberda, Historia angielskich quasi-kontraktów..., s. 66., tenże, Podobieństwa między prawem rzymskim i angielskim na przykładzie regut dotyczacych postępowania i zobowiazań, „Forum Prawnicze” 2012, nr 1, s. 52 i nn.; Tenże, Zasada bezpodstawnego wzbogacenia w prawie angielskim, „Studia Prawa Prywatnego” 2014, nr 2, s. 93.

19 J.A. Schaefer, Beyond a Definition..., s. 193, 204-205, passim. 
do czynienia z wadą skutkującą nielegalnością umowy, to problem związany z rozpoznaniem różnic pomiędzy nieważnością względną a nieważnością bezwzględną nie ma większego znaczenia wskutek określonego układu kompetencji sędziego do rozpoznania sprawy pod względem materialnym ${ }^{20}$.

Nauka dostrzega problem bardzo ważny (obecny także w tradycji kontynentalnej) wynikający ze stosowania niektórych terminów dotyczących wadliwości w sposób zamienny, trywializujący dystynkcje pomiędzy poszczególnymi sankcjami wadliwości ${ }^{21}$. Podobnie jak w prawie kontynentalnym zwraca się celnie uwagę na występowanie wielu niejasnych sposobów tworzenia typologii i systemu wadliwych umów 22 . Podkreśla się, że rodzaje wadliwych umów wskazują na różne stopnie osłabienia skuteczności i nie są w common law wyodrębniane z zadowalającą precyzją ${ }^{23}$.

Przed omówieniem głównych podstaw sankcji porównywalnej do nieważności bezwzględnej, należy zapowiedzieć, że model typologii sankcji wadliwości common law nie jest spójny. Poglądy zarówno orzecznictwa, jak i doktryny w wielu przypadkach potrafią być tak samo niejasne lub wewnętrznie sprzeczne jak w krajach ius civile. Co więcej: na systematykę sankcji wadliwości mocny wpływ wywiera materialność i istotność naruszeń - niezgodność celu lub treści czynności prawnej z prawem lub moralnością (porządkiem publicznym) stanowi z reguły o nielegalności (stosunkowo rzadko mowa jest o nieważności $a b$ initio), naruszenie innych wymogów uruchamia sankcję nieważności lub wzruszalności. Od strony terminologicznej najistotniejsze wahanie występuje pomiędzy stosowaniem nieegzekwowalności i nieważności ${ }^{24}$.

20 Tamże, s. 195. Autor zwraca uwagę na rozpoznawanie przez sądy angielskie zróżnicowanych stopni nieważności od przynajmniej XVII w. Ówczesne klasyfikacje nie miały wiele wspólnego z obecnymi koncepcjami common law na temat nieważności. Wydaje się, że autor zauważył większe skoncentrowanie ówczesnej nauki prawa na prymacie niezgodności z ustawą, która zawsze powodowała brak możliwości opierania roszczeń na takiej czynności prawnej lub związania nią stron.

21 Tamże, s. 193-194.

22 Tak m.in. tamże, s. 193, passim.

23 J. Beatson, Anson's Law of Contract, wyd. 27, Oxford 1998, s. 19.

24 Ze względu na tak szeroki zakres znaczeniowy terminu illegal w praktyce niektóre rodzaje wadliwych umów traktowane są jako nieważne, nie zaś nielegalne. Niekiedy identyfikowane są stany pośrednie, ponieważ relacja pomiędzy aktem prawnym nieważnym nie jest taka jak pomiędzy słowami „tak” a „nie”. Często więc niektóre skutki prawne są wywołane przez umowę - por. wraz z przywołanymi wypowiedziami sądów J. Beatson, Anson's Law..., s. 19; G.C. Cheshire, C.H. Fifoot, M. Furmston [w:] Law of Contract, pod red. M.P. Furmstona, wyd. 11, London 1986, s. 343-344. 


\subsection{Ogólna charakterystyka sankcji void i voidable}

Sankcji nieważności bezwzględnej odpowiada (w przypadku naruszeń mniej poważnych od nielegalności lub niemoralności umowy) kategoria void contracts, a wzruszalności (nieważności względnej, unieważnialności) voidable contracts.

Problem określenia istoty ww. sankcji pojawia się w przypadku nielegalności i niezaskarżalności umów (oraz trustów). Wyniki analizy różnych krajów tradycji common law uzasadniają stwierdzenie, że nielegalność należy uznać za ogólną kategorię, która obejmuje określone rodzaje naruszeń ważnie zawartej umowy (przyczyny wadliwości treści, celu lub sposobu wykonania umowy). Nie jest to jednak sankcja tylko prawa materialnego, a bardziej skutek wady na gruncie prawa formalnego polegający na braku skargi procesowej, braku zaskarżalności, bardzo podobny do stanu nieważności, jednak istotnie różny w zakresie roszczeń restytucyjnych oraz zarzutów przeciwko roszczeniom o zwrot bezpodstawnego wzbogacenia.

W systemach common law dla potrzeb wykładu o wadliwych umowach wyodrębnia się wspólną płaszczyznę czynników prowadzących do ostatecznego stanu nieważności umowy (vitiating factors), które polegają na naruszeniu następujących wymogów:

- sprecyzowanie przedmiotu umowy (klauzuli umownej) i pewność dokonanych uzgodnień (certainty),

- istnienie przyczyny transakcji (consideration),

- zamiar wywołania skutków prawnych (intent to create legal relations),

- brak naruszenia ustawy lub moralności (compatibility with tests of illegality and public policy),

- zachowanie przesłanek ważności umowy poręczenia i tzw. gwarancji poręczyciela,

- zachowanie zasady privity of contract, tj. przełamania zasady skuteczności umowy tylko pomiędzy stronami umowy wyłącznie na dopuszczalnych zasadach

- wprowadzenie w błąd, oszustwo, błąd, przymus oraz wyzysk ${ }^{25}$.

Od strony cech formalnych sankcji sprzężonej z daną wadliwością należy podkreślić, że nie powodują one jednolitych następstw, ponieważ niektóre czynniki wywołują sankcję nieważności bezwzględnej, inne sankcję wzruszalności

25 Tak, np. N. Andrews, Arbitration and Contract Law. Common Law Perspectives, Cham 2015, s. 181-199. Autor podaje jednocześnie szczególne wymogi: formy w odniesieniu do czynności prawnych pod tytułem darmym (a gratuitous promise). Odnośnie do zasady privity of contract autor wskazuje także na jej unormowanie w The Contracts (Rights of Third Parties) Act 1999 (England and Wales). W zakresie szczegółowego porównania przesłanek sankcji nieważności ab initio i sankcji wzruszalności - por. szerzej M. Chen-Wishart, The Nature of Vitiating Factors in Contract Law [w:] Philosophical Foundations of Contract Law, red. P. Saprai, G. Klass, G. Letsas, Oxford 2014, s. 299-300. 
albo sankcję niezaskarżalności, połączoną z zarzutem nielegalności ${ }^{26}$. Inaczej wówczas przebiega procedura doprowadzenia do ostatecznej nieważności skutków prawnych. Niemniej jednak jest to interesujące podejście do nieważności jako stanu nieważności, co pozwala traktować wszelkie środki prawne prowadzące do tego stanu w sposób jednolity.

Ponadto $w$ ramach głównych podstaw unieważnienia lub nieważności wyodrębnia się identycznie jak w ius civile wady oświadczenia woli: błędu (mistake), wprowadzenia celowego w błąd (misrepresentation), bezprawnego nacisku (undue influence), przymusu (duress), wyzysku w wyniku rażącej niesprawiedliwości kontraktowej lub nadmiernego wpływu na drugą stronę podczas zawierania umowy (unconscionability or inequality of bargaining power), a także brak zdolności do czynności prawnych (capacity) ${ }^{27}$. W prawie dotyczącym restytucji - bezpodstawnego wzbogacenia - dodaje się dodatkowo działanie bez umocowania (lack of authority) ${ }^{28}$.

\subsection{Definicje void i voidable contracts}

W niektórych systemach common law można w zasadach typu soft law (restatement) spotkać się z ujęciem dorobku nauki i judykatury w normy syntetyczne. Dzięki temu powstaje możliwość zapoznania się z zasadami ogólnymi oraz definicjami wyważającymi najważniejsze tendencje orzecznicze i poglądy doktryny.

W prawie amerykańskim zdefiniowano umowy nieważne, wzruszalne lub niezaskarżalne w Restatement of Contracts (1932). Umowę nieważną zdefiniowano jako umowę, która nie wywołała nigdy skutków prawnych. Definicja dość syntetycznie stwierdzała, że nieważna umowa to umowa dotycząca sytuacji, gdy oświadczenia woli lub kilka oświadczenia woli, w odniesieniu do których naruszenia prawo nie przyznaje żadnych roszczeń ani w inny sposób nie uznaje obowiązku świadczenia usług przez osobę składającą oświadczenie woli (promisor). Doktryna podkreślała wymiar procesowy - na podstawie takiej umowy nie można dochodzić przed sądem roszczeń ${ }^{29}$.

W drugiej edycji zasad, co warto odnotować, w przypadku void contract przyjęto za zasadę przywrócenie stanu poprzedniego na mocy skargi restytucyjnej ${ }^{30}$.

26 J. Beatson, Anson's Law..., s. 19; G.C. Cheshire, C.H. Fifoot, M. Furmston [w: ] Law of Contract, s. 189.

27 N. Andrews, Arbitration and Contract..., s. 189-199.

28 Por. bliziej J.D. McCamus, The Restatement (Third) of Restitution and Unjust Enrichment, „Canadian Bar Review” 2011, nr 2, s. 451.

29 Tak Chitty on Contracts..., s. 80.

30 Tamże, s. 80. Por. także J.A. Schaefer, Beyond a Definition..., s. 197-198, co do rozwoju poglądów i definicji umów void i voidable w trakcie prac nad pierwszą wersją Restatement 
Należy wyjaśnić, że formalnie w The Restatement (Second) of Contracts z $1981 \mathrm{r}$. nie podaje się definicji pojęcia kategorii void contracts. W $\$ 7$ The Restatement (Second) of Contracts zdefiniowano voidable contracts natomiast w $\S 8$ The Restatement (Second) of Contracts normuje się sankcje unenforceable contracts. Termin void contracts jest wyjaśniony w komentarzu do § 7, w pkt A. Podkreśla się, podobnie jak w komentarzach do 1. edycji, że z punktu widzenia definicji umowy wskazanej w $§ 1$ The Restatement (Second) of Contracts, określenie void contracts nie daje podstaw do uznania nieważnej umowy za umowę. W komentarzu formułuje się trafne spostrzeżenie, że mówienie o nieważnej umowie to sprzeczność sama w sobie: jeżeli porozumienie jest nieważne, to nie można określać takiego działania jako umowy ${ }^{31}$. Tylko jeżeli zdefiniowałoby się umowę jako działanie stron bez względu na ich skutek prawny, umowa mogłaby być określana jako nieważna umowa ${ }^{32}$. Uznaje się, że termin „nieważna umowa” jest wewnętrznie sprzeczny, ponieważ umowa obejmuje zawsze pewien element egzekwowalności (enforceability). Podkreśla się przy tym, że taki problem nie zachodzi w sytuacji terminu „nieważne porozumienie”. Z tej przyczyny, że porozumienie nie zakłada dojścia do skutku stosunku prawnego, a jedynie łączy się ze złożeniem oferty i jej przyjęciem. Tak samo dopuszcza się użycie określenia nieważne oświadczenie woli (void promise), argumentując, że termin void promise ma jedynie wskazać na zamiar wywołania skutku prawnego (bez implikacji, czy oświadczenie to będzie prawnie wiążące lub w inny sposób prawnie doniosłe) ${ }^{33}$. Ponadto możliwa jest sytuacja rozbieżności pomiędzy ofertą i jej przyjęciem, wówczas nie jest to zarówno umowa lub porozumienie, jedynie są to oświadczenia woli. Zwraca się uwage, że indywidualne oświadczenia woli stron nie są całkowicie pozbawione skutków prawnych, każde z nich może być bowiem prawnie skuteczne wobec stworzenia dla drugiej strony możliwości jego przyjęcia ${ }^{34}$.

Podobny pogląd został sformułowany w prawie polskim w $1986 \mathrm{r}$. Zbigniew Radwański wskazał, że tzw. bezwzględnie nieważne czynności prawne nie należą

of Contracts, od 1924 r. Autor trafnie zauważa, że definicja void contract ostatecznie przyjęta w $\$ 13$ (jako tzw. special note) była przeciwieństwem definicji umowy - tamże, s. 198. Autor bardzo krytycznie ocenia sens jej definiowania - stwierdza, że skoro „void contract” mogło obejmować tylko transakcje, które nie były w ogóle umowami, to stało się to pojęcie oksymoronem i ,intelektualnym faux pas”.

31 The Restatement (Second) of Contracts (1981); por. § 1 oraz komentarz pkt a) do $\S 7$ The Restatement (Second) of Contracts.

32 Por. komentarz do $§ 7$ Restatement (Second) of Contracts, pkt a.

33 Tak A.L. Corbin, Corbin on contracts. One volume edition, St. Paul 1952, s. 7 . W doktrynie angielskiej identycznie Chitty on Contracts..., s. 80.

34 Por. szerzej A.L. Corbin, Corbin on contracts..., s. 11. Autor zwraca m.in. uwagę, że oświadczenie woli lub porozumienie, które całkowicie nie wywołuje żadnych zmian w stosunkach prawnych, łącznie z takimi następstwami, jak np. estoppel, może być poprawnie nazwane void promise / void agreement. 
do klasy czynności prawnych prawa cywilnego. Nie powinno się ich rozpatrywać jako odmiany wadliwych czynności prawnych. Autor celnie zauważył, że o wadliwych czynnościach prawnych można mówić tylko wtedy, gdy wywołują przynajmniej niektóre skutki prawne ${ }^{35}$.

Interesujące jest, że podobnie do nieważności, nielegalność umów rozpatrywana na płaszczyźnie teoretycznej skłania przedstawicieli nauki do stwierdzenia, że także termin „nielegalna umowa” jest wewnętrznie sprzeczny, ponieważ nielegalne umowy są z definicji nieegzekwowalne (unenforceable); w ten sposób umowy nielegalne nie są „umowami w ścisłym znaczeniu pojęcia umowy, ponieważ brak jest koniecznego elementu, którym jest dostępność środków ochrony prawnej w razie naruszenia umowy ${ }^{36}$. Proponuje się dla uniknięcia powyższej sprzeczności zastąpienie terminu „nielegalna umowa” sformułowaniem: „nielegalna transakcja” ${ }^{37}$.

Warto odnotować także inną niekonsekwencję w charakterystyce umów nieważnych: dostrzec można skłonność do utożsamiania ich z umowami nieważnymi z powodu nielegalności ${ }^{38}$. Spotkać można wypowiedzi, że nielegalna umowa może być określona mianem nieważnej bezwzględnie (void), jednak ten rodzaj następstw nielegalności zależy od natężenia naruszenia przepisów prawa lub moralnej niegodziwości i nie należy przyjmować, że skutek nielegalności jest zawsze identyczny ${ }^{39}$.

Termin void jest rozumiany jako synonim braku jakichkolwiek skutków prawnych. Pomimo to umowa nieważna w zakresie pierwotnie zamierzonych skutków prawnych, może wywołać skutki prawne w inny sposób ${ }^{40}$. Kategoria void oznacza brak istnienia, absolutny brak skutków prawnych. $\mathrm{Z}$ tego powodu wypracowano kilka osłabionych faz owego stanu nieistnienia ${ }^{41}$. Problemem w wyjaśnieniu definicji jest okoliczność, że termin void jest stosowany także jako określenie mówiące jednocześnie o nieważności i niezaskarżalności, natomiast

35 Por. szerzej Z. Radwański, Jeszcze w sprawie bezwzględnie nieważnych czynności prawnych, „Państwo i Prawo” 1986, nr 6, passim wraz z krytyką sformułowaną przez A. Szpunar, O konwalidacji nieważnej czynności prawnej, „Państwo i Prawo” 1986 nr 5, passim; Tenże: O konwalidacji wadliwych czynności prawnych, „Państwo i Prawo” 2002 nr 7, passim.

36 Por. wraz z przywołanym tam dalszym piśmiennictwem, J.P. Kostritsky, lllegal Contracts and Efficient Deterrence: A Study in Modern Contract Theory, „Iowa Law Review” 1988, vol. 74, s. 116.

37 J.P. Kostritsky, Illegal Contracts and Efficient Deterrence..., s. 116.

38 Chitty on Contracts..., s. 81.

39 Tamże, s. 81, por. także B.S. Markesinis, H. Unberath, A. Johnston, The German Law of Contract: A Comparative Treatise, wyd. 2, Oxford 2006, s. 242, wraz z dalszą literaturą.

40 N.J. Thompson, The Rights of Parties to Illegal Transactions, Marrickville 1991, s. 5-6.

41 J.A. Schaefer, Beyond a Definition..., s. 195. 
stwierdzenie, że umowa jest nieważna bezwzględnie z mocy ustawy nie powoduje, że uznaje się automatycznie umowę jako nielegalną ${ }^{42}$.

W doktrynie angielskiej proponuje się rezygnację z terminu void ze względu na to, że ma on zastosowanie do spraw zasadniczo odmiennych od siebie pod kątem przyczyn wadliwości umów, ponadto nie jest stosowany w jednakowym znaczeniu i nie daje tych samych rezultatów ${ }^{43}$. Nie jest to propozycja przyjęta powszechnie zarówno w prawie angielskim lub innych systemach common law ${ }^{44}$.

Zasygnalizowany powyżej skutek nielegalności zbliżony jest w pewnym zakresie do pewnych następstw niegodziwego świadczenia w rozumieniu prawa polskiego lub innych systemów ius civile. Równolegle określenie illegal implikuje również występowanie kryminalnych lub bezprawnych zachowań lub zamiarów. To zaś w prawie umów jest sytuacją mylącą. Często tzw. nielegalność umowy w ogóle nie dotyczy czynów zabronionych ustawą karną ${ }^{45}$.

Umowę sankcjonowaną wzruszalnością (voidable) charakteryzuje się w $\S 7$ The Restatement (Second) of Contracts, podobnie jak w tradycji kontynentalnej, prawem jej uchylenia na mocy oświadczenia uprawnionej strony lub możliwością potwierdzenia. Wzruszenie umowy przyjmuje się np. w przypadku błędu, podstępu ${ }^{46}$, braku zdolności do czynności prawnych oraz nieuczciwego nacisku ${ }^{47}$. Zarówno uchylenie się od umowy, jak i jej potwierdzenie możliwe jest

42 Raport The Law Commission, Illegal Transactions: The Effect of Illegality on Contracts and Trusts, „Consultation Paper” 1999, nr 154, http://www.lawcom.gov.uk, s. 5.

43 G.C. Cheshire, C.H. Fifoot, M. Furmston [w: ] Law of Contract, s. 344.

44 Tytułem przykładu można powołać pogląd wyrażony w raporcie rządu Singapuru, Law Reform Committee, Relief from Unenforceability of Illegal Contracts and Trusts, 5.7.2002 r., publ. na www.agc.gov.sg, przypis 35, w którym wyjaśnia się, że choć niektóre podręczniki prawa, szczególnie te starsze, posługują się określeniem, że nielegalna umowa jest nieważna ab initio, jednak lepiej jest stosować określenie, że nielegalna umowa jest „jedynie nieegzekwowalna”. Autorzy raportu argumentują, że jeżeli nielegalna umowa byłaby nieważna bezwzględnie, wówczas nie byłaby oparciem dla roszczeń z tytułu naruszenia umowy, ani nie dawałaby roszczeń osobie, która została na mocy takiej umowy posiadaczem. Autorzy zauważają jednak, nieco ustając w dążeniu do klarowności poglądów, że niekiedy termin nieważny (void) jest synonimem słowa nieegzekwowalny (unenforceable).

45 Zwraca się na to uwagę m.in. w piśmiennictwie kanadyjskim - por. The British Columbia Law Institute, Report on Relief Under Legally Defective Contracts: The Uniform Illegal Contracts Act, 10.2008, raport nr 52, www.bcli.org, s. iii. W prawie angielskim na mocy Proceeds of Crime Act 2002 wprowadzono możliwość orzeczenia konfiskaty korzyści uzyskanych w wyniku czynu zabronionego - por. The Law Commission, The Illegality Defence, A Consultative Report, „Consultation Paper" 2009, nr 189, http://www.lawcom.gov.uk, s. 16.

46 Podstęp może jednak w skrajnym ujęciu prowadzić do bezwzględnej nieważności gdy osoba składająca oświadczenie woli została oszukana do tego stopnia, że nie wie, co podpisuje, nie rozumie natury swego działania, podobnie na ważność wpływa przymus - por. $\S \S 163$, 174, 175 The Restatement (Second) of Contracts.

47 J.B. Racine, L. Sautonie-Laguionie, A. Tenenbaum, G. Wicker, European Contract Law, Materials..., s. 358. 
w pozasądowym trybie ${ }^{48}$. Należy wspomnieć, że podobnie definiowano voidable contract w pierwszej wersji modelowych reguł prawa umów. Zarówno obecny $\S 7$, jak § 13 poprzedniej edycji Restatement of the Law of Contracts (1932), stanowiły, że sankcja ta oznacza wadliwość umowy, gdzie jedna lub więcej stron uprawniona jest do unieważnienia stosunku prawnego, stworzonego przez zawarcie umowy, poprzez skorzystanie $\mathrm{z}$ tego prawa. Przepis ten przewiduje również potwierdzenie umowy, a tym samym wygaśnięcie uprawnienia do unieważnienia umowy ${ }^{49}$. Nauka amerykańska podkreśla, że koncepcja wzruszalnych umów nie jest jednolita, a na tle poszczególnych umów można ustalić znaczące różnice. Niezależnie od tego każdorazowo jedna ze stron ma prawo do unieważnienia lub potwierdzenia umowy ${ }^{50}$.

Także w prawie angielskim dokonano zdefiniowania omawianych odmian nieważności umów, w A Restatement of The English Law of Contract z 2016 r. Na wzór amerykańskich restatements, A. Burrows, z zespołem sędziów, naukowców i praktyków, opublikował w 2016 r. zasady angielskiego prawa umów (A Restatement of The English Law Of Contract) ${ }^{51}$.

W Części 7 zatytułowanej w sposób odbiegający nieco od dotychczasowej praktyki: „Czynniki powodujące wadliwość umowy” (Factors Rendering A Contract Defective), wymienia się następujące instytucje prawne: Mistake, Misrepresentation, Duress, Undue influence, Misrepresentation, Illegitimate threat or undue influence by a third party, Legislative consumer protection against misleading or aggressive commercial practices, Exploitation of weakness, Non-disclosure, Incapacity, Illegality and public policy ${ }^{52}$.

Nieważność bezwzględna jest definiowana w Części 7, artykuł 34, gdzie w ust. 2 proponuje się syntetyczną definicję void contract: Nieważna umowa jest nieważna od samego początku $i$ nie tworzy żadnych zobowiazan umownych; ale może wystapić przypadek, że tylko jedna strona może opierać swoje roszczenia

48 Por. także definicję voidable contract $\mathrm{w} \S 7$ The Restatement (Second) of Contracts: A voidable contract is one where one or more parties have the power, by a manifestation of election to do so, to avoid the legal relations created by the contract, or by ratification of the contract to extinguish the power of avoidance.

$49 \S 13$ of The Restatement of the Law of Contracts (1932): A voidable contract is one where one or more parties thereto have the power, by a manifestation of election to do so, to avoid the legal relations created by the contract or by ratification of the contract to extinguish the power of avoidance.

50 Szerzej: A.L. Corbin, Corbin on contracts..., s. 12-13.

51 Por. szerzej, A. Burrows, A Restatement of The English Law Of Contract, Oxford 2016, s. Xinn.

52 Zasady A Restatement of The English Law Of Contract wyodrębniają do części 2 wymogi związane $z$ przesłankami ważności umowy na etapie jej zawierania (zgodne oświadczenia woli, istnienie przyczyny porozumienia, pewność i określoność porozumienia, zamiar wywołania skutków prawnych, zachowanie wymaganej formy) - por. szerzej, A. Burrows, A Restatement of The English..., s. 8-10. 
na unieważnieniu umowy ${ }^{53}$. Komentarz wyjaśnia, że ten stan faktyczny dotyczy głównie jednostronnego błędu ${ }^{54}$.

Sankcję wzruszalności normuje art. 34 ust. 3 od strony podmiotu uprawnionego i zainicjowania procesu unieważnienia: umowa, w odniesieniu do której strona pokrzywdzona czynnikiem powodującym wzruszalność umowy (uprawniony do roszczenia), może wybrać, aby umowę unieważnić, a umowa jest ważna do czasu unieważnienia; po unieważnieniu umowa jest nieważna od początku ${ }^{55}$. Unieważnienie odróżnia się od odstąpienia od umowy (termination) na mocy skargi z tytułu naruszenia umowy lub na skutek istotnej zmiany okoliczności (frustration). Unieważnienie nie wymaga skierowania sprawy do sądu, a do wywołania skutku prawnego wystarczy przedsądowe złożenie oświadczenia woli oraz w przypadku, jeżeli to niemożliwe, wyrażenia przez zachowanie uprawnionego, że umowa jest unieważniona (art. 34 ust. 4 ww. Zasad) ${ }^{56}$.

W prawie angielskim zwraca się uwagę, przy okazji definiowania umów wzruszalnych, na kwestię częściowego unieważnienia (partial rescission), która może być sprzeczna z zasadą całkowitego unieważnienia umowy, a efekty porównywalne do częściowego unieważnienia można uzyskać dzięki rozliczeniom restytucyjnym. Jednocześnie w prawie angielskim, w The Insurance Contracts Act 2014 oraz The Consumer Insurance (Disclosure and Representations) Act 2012, wprowadzono formę częściowego unieważnienia z tytułu świadomego wprowadzenia w błąd lub braku ujawnienia istotnych informacji ${ }^{57}$.

\subsection{Definicje unenforceable contracts}

Perspektywa prawnoporównawcza wskazuje trochę paradoksalnie na tę sankcję jako najbardziej zbliżoną do nieważności bezwzględnej (absolutnej) w tradycji kontynentalnej. W przypadku tej sankcji, określanej terminem niezaskarżalności (nieegzekwowalności) ${ }^{58}$ (unenforceable contracts) mamy jednocześnie do czynienia z najpoważniejszą odrębnością w porównaniu do tradycji ius civile. Termin

53 A void contract is invalid from the start and creates no contractual obligations but it may be that only one party can rely on the contract being void-A. Burrows, A Restatement of The English..., s. 27.

54 Tamże, s. 170, 180-181.

55 A voidable contract is one that the party affected by the factor rendering the contract voidable (the 'claimant') can choose to rescind but is valid unless rescinded; and the effect of rescission is to invalidate the contract from the start-tamże, s. 27.

56 Por. wraz z przywołanym orzecznictwem tamże, s. 171.

57 Por. tamże, s. 171.

58 Zaproponowane tłumaczenie terminu unenforceable ma na celu zwrócenie uwagi na główny skutek w zakresie możliwości egzekwowania roszczeń kontraktowych lub z bezpodstawnego wzbogacenia. Takiej funkcji nie zapewni posłużenie się sformułowaniem „bezskuteczny”, 
ten nie jest używany jednolicie. W szeregu wypowiedzi judykatury i doktryny mniejsze znaczenie przyznaje się spójnej terminologii. Zwraca się trafnie uwagę, że mamy do czynienia raczej z sankcją procesową (proceduralnej natury) niż sankcją prawa materialnego ${ }^{59}$.

Umowę nieegzekwowalną definiuje się $\mathrm{w}$ prawie amerykańskim w $\S 8$ The Restatement (Second) of Contracts. Umowa nieegzekwowalna to umowa, której naruszenie nie powoduje powstania roszczenia o odszkodowanie ani o jej wykonanie, jednakże naruszenie umowy może powodować powstanie obowiązku wykonania umowy, chociażby nie została ona zatwierdzona. Sankcję unenforceable stosuje się zarówno w razie naruszenia ustaw, jak też naruszenia zasad porządku publicznego (public policy) ${ }^{60}$ lub niezgodności z moralnością ${ }^{61}$, a także w przypadku naruszenia przepisów odnośnie do formy umowy (Statute of Frauds $)^{62}$. Jest to także skutek wystąpienia przedawnienia ${ }^{63}$.

Wynik porównania nasuwa się per se: tam gdzie w prawie kontynentalnym stosowane byłyby różne odmiany sankcji nieważności (bezwzględnej, absolutnej, relatywnej lub względnej), w common law zastosowanie znajduje ta norma sankcjonująca. Sprzężona $\mathrm{z}$ tą sankcją wadliwość określana jest najczęściej jako illegality lub illegal contract ${ }^{64}$.

Rozbudowanie i skomplikowanie tej instytucji prawnej, katalog naruszeń, skutki, wyjątki od zasad ogólnych w zakresie pozbawienia roszczeń z bezpodstawnego wzbogacenia nastręcza spore trudności dla praktyki. W kilku krajach ustawowo unormowano najważniejsze kwestie dla ujednolicenia case law. Albo podjęto prace na nad jej uregulowaniem ${ }^{65}$.

W A Restatement of The English Law of Contract 2016, w art. 34 ust. 6 zaproponowano następującą definicję umowy nieegzekwowalnej: nieegzekwowalna umowa tworzy zobowiązania umowne, ale nie może być egzekwowana

ponieważ termin ten ma zbyt wiele utrwalonych znaczeń w polskim prawie i innych systemach kontynentalnych: nie oddaje procesowej natury skutku zastosowania tej sankcji.

59 G.C. Cheshire, C.H. Fifoot, M. Furmston [w: ] Law of Contract, s. 189.

60 R.A. Mann, B.S. Roberts, Smith and Roberson's Business..., s. 225-227. Wśród ustawowych przypadków autorzy wskazują na naruszenia przepisów o grach i zakładach, zakazujących lichwy (usury statutes) oraz wykonywania niektórych rodzajów działalności handlowej w niedziele (Sunday Statutes). Ostatnia grupa przepisów nazywana jest Blue Laws, ich naruszenie powoduje, że sąd uzna ważność potwierdzenia umowy dokonanego przez strony, jeżeli nastąpi to po „weekendzie” - por. tamże, s. 226.

61 G.H. Treitel, The Law of Contract, London 1987, s. 372.

62 J. Beatson, Anson's Law..., s. 20. W common law tradycyjnie wymogi formalne regulują przepisy typu Statute of Frauds, gdzie sankcja ta jest opisana zdaniem „no action shall be brought".

63 R.A. Mann, B.S. Roberts, Smith and Roberson's Business Law, Mason [Ohio] 2005, s. 162, 164, szerzej A.L. Corbin, Corbin on contracts..., s. 13.

64 Por. J. Beatson, Anson's Law..., s. 19-20.

65 The Law Commission, Illegal Transactions..., s. 46. 
przez jedna lub, w pewnych okolicznościach, przez każda ze stron ${ }^{66}$. W komentarzu wręcz standardowo zwraca się uwagę na problem nierozróżniania terminologii norm sankcjonujących ${ }^{67}$.

Sankcję unenforceable niezbyt konsekwentnie odróżnia się od nieważności umowy ${ }^{68}$. Jak zostało wspomniane powyżej, termin void łączony jest często $\mathrm{z}$ terminem unenforceable w niektórych tekstach normatywnych, np. art. 5-321, art. 5-322 The New York General Obligations Law.

Nieważna umowa w całości nie wywołuje skutków prawnych oraz co do zasady przysługują roszczenia restytucyjne. Odmiennie natomiast nieegzekwowalność umowy sprowadza się do tego, że to, co już zostało wykonane w ramach tak wadliwej umowy, zostaje utrwalone, natomiast odpada możliwość żądania wykonania pozostałej części umowy ${ }^{69}$. Sankcja unenforceable może w danym przypadku zostać uchylona wskutek konwalidacji, w szczególności przy naruszeniu przepisów o formie $\mathrm{e}^{70}$ albo w przypadku nielegalności trustów ${ }^{71}$. Odpowiada to uznawaniu konwalidacji w systemach kontynentalnych (np. wraz z wprowadzeniem kodeksowej podstawy prawnej, jak np. w prawie holenderskim ${ }^{72}$ ).

Niezbędne dla charakterystyki sankcji nieegzekwowalności jest wskazanie na bardzo istotną cechę formalną tej sankcji w przypadku nielegalnych lub niemoralnych umów, tj. zasadę braku interwencji w spór ${ }^{73}$. W tym znaczeniu jest to absolutny brak skutków prawnych, rozciągający się także na roszczenie o przywrócenie stanu poprzedniego ( $\mathrm{w}$ pewnym uproszczeniu $\mathrm{z}$ tytułu bezpodstawnego wzbogacenia).

Dla naszego kręgu prawnego paradoksalnie nieważność jako sankcja jest w swych skutkach mniej dolegliwa aniżeli sankcja z tytułu nielegalności umowy $\mathrm{w}$ common law. Ten ostatni aspekt zostanie szczegółowo poruszony w dalszej części, ponieważ wywarł bardzo duży wpływ na common law, m.in. inicjatywy zmiany prawa w Anglii oraz Kanadzie. Pośrednio wyniki prac nad reformą illegality

66 An unenforceable contract creates contractual obligations but cannot be enforced by one or, in some circumstances, either party - A. Burrows, A Restatement of The English..., s. 28.

67 Por. szerzej tamże, s. 174. Autor zwraca także uwagę na zmianę stanu prawnego w zakresie rozporządzeń nieruchomościami na mocy Law of Property (Miscellaneous Provisions) Act 1989, który wprowadził nieważność za brak formy pisemnej i formy podpisu.

$68 \mathrm{Na}$ stosowanie nieprecyzyjnie terminologii i brak konsekwencji zwraca się niejako zwyczajowo uwagę w literaturze przedmiotu - por. J.A. Schaefer, Beyond a Definition..., s. 194.

69 Por. np. The British Columbia Law Institute, Report on Relief Under Legally Defective..., s. 6-7.

70 J. Beatson, Anson's Law..., s. 20.

71 Por. wraz z przywołanym tam orzecznictwem, The Law Commission, The Illegality Defence..., s. 115 i nn.

72 Por. art. 3:58 holenderskiego Kodeksu cywilnego (Burgerlijk Wetboek) oraz art. 76 projektu I Księgi Kodeksu cywilnego z 2015 r.

73 The British Columbia Law Institute, Report on Relief Under Legally Defective..., s. 25. 
trafiły następnie do soft law (PECL, UPICC, DCFR), a następnie do prawa polskiego w tzw. akademickim projekcie I Księgi Kodeksu cywilnego z 2015 r.

\section{$\S 3$. Sankcja z tytułu nielegalności (Illegality)}

\subsection{Cechy formalne normy sankcjonującej}

Cechy formalne sankcji nieważności bezwzględnej uzasadniają, przy przedstawionych problemach natury komparatystycznej, ich przedstawienie na tle instytucji illegality ${ }^{74}$.

Nielegalność może być sankcjonowana definitywną nieważnością skutków prawnych, całkowitą lub częściową, rozciągać się na rozszerzenia o przywrócenie stanu poprzedniego, a także powodować brak skutków prawnych tylko w szczególnych okolicznościach oraz wyłącznie wobec określonych grup podmiotów, np. wobec organów podatkowych lub celnych ${ }^{75}$. Nielegalność może również sprowadzać ,jedynie” nieegzekwowalność umowy w całości lub części bez przyjmowania nieważności bezwzględnej. To rozróżnienie powoduje w konsekwencji utrwalenie stanu zaistniałego po wykonaniu umowy, np. poprzez przeniesienie na mocy takiej umowy tytułu prawnego, jeżeli jedna ze stron zdążyła wykonać swe zobowiązanie. Taka sytuacja może mieć miejsce jedynie co do zasady, ponieważ i tutaj dopuszcza się wyjątki ${ }^{76}$. Natomiast utrata roszczeń $\mathrm{z}$ bezpodstawnego wzbogacenia nie byłaby możliwa w przypadku nieważności bezwzględnej, która to sankcja w odróżnieniu od nielegalności wprowadza brak jakichkolwiek skutków (no legal effect) $)^{77}$.

Głównym celem - cechą normy sankcjonującej sprzężonej z przyczyną nielegalności - jest doprowadzenie do stanu nieegzekwowalności umowy, który w swym skutku głównym jest zbliżony do zamiany zobowiązania w zobowiązanie niezupełne lub umowę ważną, ale niezaskarżalną w sensie procesowym ${ }^{78}$.

74 Na przykład illegality jako kategorię zbiorczą proponują J. Beatson, Anson's Law..., s. 334 i nn. oraz E. McKendrick, Contract Law, 3 wyd., London 1997, s. 286 i nn. Autorzy omawiają jedynie illegality, nie wyróżniając odrębnie umów dotkniętych nieważnością (void) w typologii sankcji.

75 P. Gillies, Concise Contract Law, Sydney 1988, s. 148.

76 Por. np. R. Youngs, English, French and German Comparative Law, London 1998, s. 375. Takie odstępstwo nie obejmuje gier z zakładów z naruszeniem ograniczeń ustawowych por. dalsze uwagi poniżej.

77 P. Gillies, Concise Contract..., s. 148.

78 Por. definicję odwołującą się do procesowego aspektu nieegzekwowalności umowy, wg $\S 14$ The American Restatement of the Law of Contracts: An unenforceable contract is one which the law does not enforce by direct legal proceedings, but recognizes in some indirect or collateral way as creating a duty of performance, though there has been no ratification. 
Pomimo instytucjonalnego związku z odmową prawa do przywrócenia stanu poprzedniego, funkcjonalnie illegality jest przede wszystkim reakcją na naruszenie ustaw lub moralności, porządku publicznego lub niektórych wymogów formalnych. W mniejszym stopniu eksponuje się kategorię void umów. Zaciera się przy tym wyraźne odróżnienie terminologicznie umów nieważnych (void) od nielegalnych, ponieważ często w doktrynie zetknąć się można ze stwierdzeniem „nieważny z powodu nielegalności”79. Pozwala to wyjaśnić stosunek znaczeniowy illegality do void, gdzie ten ostatni normuje skutki tzw. mniej poważnych naruszeń przepisów ${ }^{80}$.

Relacja terminów void oraz illegal przedstawia się znacznie bardziej skomplikowanie, jeżeli uwzględni się potrzebę ograniczenia skutków nielegalności umowy. Rezygnacja z terminu „nieważny” (void) na rzecz słowa „niezaskarżalny" (unenforceable) pozwala na uniknięcie sprzeczności, która związana jest z nadawaniem wykonalności i skutków prawnych umowom nieważnym bezwzględnie, gdzie dla odmiany w odwrotnej sytuacji nielegalna umowa może być źródłem, np. nabycia własności ${ }^{81}$.

Nielegalne umowy zestawia się z przypadkiem nielegalnych transakcji. Sądy w common law co do zasady wyróżniają dwie kategorie tego typu porozumień: mala in se (niezgodne z moralnością) oraz mala prohibita (dotyczące naruszenia regulacji). Istotne w tym podziale jest, że niezgodność $\mathrm{z}$ regulacjami może być traktowana jako podstawa nieważności względnej ${ }^{82}$.

W ujęciu tradycyjnym nielegalność jako wada aktywuje normę sankcjonującą, która powoduje, że umowa nie kreuje żadnych roszczeń i jest nieegzekwowalna (unenforceable). Następuje stan nieważności umowy, nie tylko połączony ze wspomnianą utratą roszczeń o wykonanie umowy ${ }^{83}$, ale także powodujący co

79 Na przykład R. Stone, The Modern Law of Contract, wyd. 6, Cavendish 2005, s. 359, The Law Commission, Illegal Transactions..., s. 61 oraz P. Richards, Law of Contract, Harlow 2005, s. 275-276 (ten autor w klasyfikacji nielegalnych umów wyróżnia umowy nieważne ab initio).

80 G.C. Cheshire, C.H. Fifoot, M. Furmston [w: ] Law of Contract, s. 344. Nie jest to jednak pogląd spójny z wypowiedziami wskazującymi, że termin void oznacza mocniejsze następstwa wadliwości niż termin unenforceable, który używany jest na określenie skutku nielegalności umowy. Jeżeli umowa jest jedynie nieegzekwowalna może być wówczas użyta jako obrona przed określonymi roszczeniami - tak G.H. Treitel, The Law..., s. 143. Termin void używa się na określenie prawnego braku istnienia umowy - J. Beatson, Anson's Law..., s. 83. Często też w doktrynie obrazowo stwierdza się, że słowo void jest mniej dramatyczne niż illegality, co jest mimo wszystko zwodnicze, ponieważ void określa bardziej drastyczne następstwo, którym jest brak jakichkolwiek skutków prawnych - P. Gillies, Concise Contract..., s. 148.

81 The Law Commission, Illegal Transactions..., s. 11, wobec faktu, że w szeregu wypowiedzi sędziowie i doktryna posługują się terminem void.

82 J.A. Schaefer, Beyond a Definition..., s. 200-201.

83 W kwestii nieważności i nielegalności w kontekście możliwości dochodzenia roszczeń restytucyjnych, por. wraz z dalszym piśmiennictwem $\mathrm{w}$ szczególności P. Birks, 
do zasady utratę możliwości przywrócenia stanu poprzedniego, odzyskania spełnionego świadczenia oraz wykluczenie roszczeń deliktowych. Te niekiedy drastyczne w danym przypadku skutki wypracowano wedle zasad słuszności (equity) w dorobku sądów kanclerskich (Court of Equity ${ }^{84}$ ); wywodzą się z zarzutu powodującego utratę prawa do ochrony prawnej na mocy wspomnianej zasady „czystych rąk" ${ }^{85}$. Podkreśla się, że różnica pomiędzy nielegalnością a innymi przyczynami nieważności polega na stosowaniu w odniesieniu do nielegalności zasady ex turpi causa non actio oritur ${ }^{86}$.

Sprzeczna z ustawą lub moralnością (porządkiem publicznym) czynność prawna nie może być wykonana. Powstaje także problem: co należy zrobić ze skutkami prawnymi, które zdążyły się pojawić do czasu wystąpienia sporu, szczególnie w związku z jednostronnym lub dwustronnym wykonaniem umowy. Co do zasady możliwe są dwa podejścia: albo przywrócenie stanu poprzedniego albo odrzucenie możliwości rozpoznawania z takiej czynności prawnej sporu przed sądem ze względu na zasady wymiaru sprawiedliwości, w szczególności na obrazę sądu skargą wywodzoną z nielegalnej umowy. W tym drugim przypadku następuje utrwalenie dokonanych skutków prawnych, łącznie z utrzymaniem straty jednej ze stron $\mathrm{w}$ związku $\mathrm{z}$ jednostronnym spełnieniem świadczenia, chyba że zaszły wyjątkowe okoliczności i sąd odrzucił zastosowanie tej reguły, przyznając roszczenie o zwrot.

Ze względu na zasadniczy mankament polegający na możliwości utrwalenia skrajnie niekorzystnych dla jednej ze stron skutków prawnych, następstwo nielegalności podlega różnorodnym korektom wedle kryteriów wypracowanych w orzecznictwie i postulowanych w doktrynie. Oparte są one najczęściej na aksjologicznym podejściu do celu naruszonych przepisów, zasad prawa lub norm moralnych; stosowanych do naruszeń dokonanych w chwili zawierania umowy, jak i na etapie wykonawczym. Widoczna jest także subiektywizacja sankcji ze względu na świadomość naruszenia merytorycznych norm sankcjonowanych.

Wyznacznikiem terminologicznych i doktrynalnych wątpliwości jest także fakt, że w Wielkiej Brytanii planowana reforma prawa pod koniec XX w. i ustawowa regulacja następstw nielegalnych umów i trustów - nie była adresowana do zdefiniowania sankcji za naruszenie przepisów o formie, sankcji z tytułu

Recovering Value Transferred Under an Illegal Contract, „Theoretical Inquiries in Law”, 2000, s. $190 \mathrm{i} \mathrm{nn}$.

84 T.A. Baloch, Unjust Enrichment and Contract, Oxford 2009, s. 30.

85 Por. wraz z dalszym piśmiennictwem i judykaturą w szczególności T. Leigh Anenson, Limiting Legal Remedies: An Analysis of Unclean Hands, „Kentucky Law Journal”, 2010, vol. 99 , s. 63 inn.

86 P. Birks, Recovering Value Transferred..., s. 162. Por. szerzej na temat stosowania tej zasady J. Halberda, Historia zobowiqzań quasi-kontraktowych w common law, Kraków 2012, s. 336, passim. 
nierównowagi (braku słuszności) kontraktowej albo wskutek braku zdolności do czynności prawnych ${ }^{87}$.

\subsection{Problem nieproporcjonalności sankcji z powodu nielegalności}

Od strony zasięgu norm merytorycznych sankcjonowanych należy wskazać na źródło problemu braku proporcjonalności sankcji. Nielegalność, jako rodzaj wadliwości, powoduje głęboką ingerencję w możliwość utrzymania w mocy zarówno zamierzonych skutków prawnych, jak też dostępność roszczeń kontraktowych lub restytucyjnych ${ }^{88}$. Nielegalność może mieć także zastosowanie do odmowy roszczeń z czynów niedozwolonych ${ }^{89}$. Nielegalność, jako sankcja lub zarzut przeciwko roszczeniom restytucyjnym lub o odszkodowanie, dotyczy bardzo różnorodnych naruszeń przepisów prawa stanowionego, moralności, wymogów formalnych oraz porządku publicznego ${ }^{90}$. W tym ostatnim przypadku różne formy naruszeń grupuje się pod zbiorczą nazwą: contracts contrary to public policy $^{91}$. Tak szeroko rozumiana sprzeczność z porządkiem publicznym oraz z przepisami ustawowymi niezależnie od ich rangi i świadomości ich naruszenia spowodowała powstanie problemu nieproporcjonalnego stosowania sankcji. W niektórych krajach dokonano zmian w prawie lub prowadzono w ostatnich latach prace nad reformą instytucji nielegalności. Największy wpływ na common law, a także na prawo modelowe w UE wywarły prace angielskiej komisji kodyfikacyjnej, szczegółowo zreferowane w raporcie angielskiej komisji kodyfikacyjnej

87 Raport The Law Commission, Illegal Transactions..., s. 3, w którym autorzy wyjaśniają, że choć wadliwości na skutek wspomnianych nieprawidłowości mogą uzasadniać sankcję nieważności, zaskarżalności lub nieegzekwowalności umowy, to jednak w każdym ze wskazanych w raporcie przypadków bardziej szczegółowe przyczyny uzasadniają unieważnienie umowy. Nie znaczy to jednak, że należy takie przypadki wadliwości uznać za podlegające kategorii nielegalności. W raporcie wskazuje się na przyczyny wadliwości wyłączone $\mathrm{z}$ tego zakresu: wprowadzenie w błąd (misrepresentation), bezprawny nacisk (undue influence), przymus (duress), wyzysk w wyniku rażącej niesprawiedliwości kontraktowej lub nadmierny wpływ podczas zawierania umowy na drugą stronę (unconscionability or inequality of bargaining power), brak zdolności do czynności prawnych (lack of capacity).

88 The British Columbia Law Institute, Report on Relief Under Legally Defective..., s. 7.

89 Por. szerzej raport angielskiej komisji kodyfikacyjnej: The Law Commission, The Illegality Defence in Tort, „Consultation Paper” No 160, www.lawcom.gov.uk, passim.

90 Sprzeczność $\mathrm{z}$ porządkiem publicznym należy rozumieć nieco szerzej niż w systemach ius civile - na temat stanowiska polskiego prawa - por. zamiast wielu Z. Radwański [w: ] System Prawa Prywatnego. t. 2: Prawo cywilne - Część ogólna, red. M. Safjan, wyd. 2, Warszawa 2012, s. 230-231.

91 Na przykład R. Stone, J. Devenney, The Modern Law of Contract, wyd. 11, Cavendish 2015, s. 391. 
z 2009 r., w którym notabene wyjaśniono także powody rezygnacji z reformy po ponad 10 latach prac $^{92}$.

Od 2003 r. w Kanadzie komisja do sprawy reformy prawa (Uniform Law Conference of Canada) podjęła działania, aby przygotować ustawę harmonizującą nielegalność z nieważnością umów wedle Kodeksu cywilnego Québec i podejścia common law. W rezultacie w 2004 r. zatwierdzono projekt, który zawierał definicję nielegalnej umowy wartą zacytowania, gdyż obrazuje ona problemy z terminologią. Definicja ta starała się wyjść im naprzeciw i art. 1 The Uniform Illegal Contracts Act brzmiał: „illegal contract” oznacza umowę która jest: „null, void, voidable, illegal, unlawful, invalid, unenforceable or otherwise ineffective as a result of a defect; (,illégal”) ${ }^{93}$. W raporcie kanadyjskiej Komisji z 2008 r. wyjaśniono, że z perspektywy kodeksu cywilnego prowincji Québec definicja ta obejmuje cały zakres umów względnie lub absolutnie nieważnych ${ }^{94}$.

W 2008 Uniform Law Conference of Canada zaproponowała także zmiany do pierwotnego projektu, m.in. rezygnację z definicji „illegal contract” poprzez zamianę na "legally defective contract" 95 .

Wartościowym przykładem regulacji ustawowej jest Nowa Zelandia. Uporządkowanie dorobku case law zapoczątkowano ustawą Illegal Contracts Act 1970. Akt ten najdalej poszedł w kierunku zastosowania sankcji kreowanej przez sędziego w sposób oparty na ustrukturyzowanych okolicznościach i czynnikach (sankcja sędziowska). Illegal Contracts Act 1970 został uchylony z dniem 1.09.2017 r. na mocy sekcji 345(1) lit. (g) the Contract and Commercial Law Act 2017.

Przepisy Illegal Contracts Act 1970 zostały inkorporowane do podrozdziału nowej ustawy: illegal contracts (sekcja 70-84 nowej ustawy), w większości zachowując zgodność z ustawą z 1970 r. Model dyskrecjonalności sędziego został utrzymany, regulowany jest szczegółowo w sekcji 75-82 ustawy. Ponadto w sekcji 71 utrzymano definicję ,illegal contract”, która z drobnymi zmianami redakcyjnymi odpowiada poprzedniej z 1970 (por. sekcja 3 Illegal Contracts Act 1970). Odwołuje się ona do źródeł wadliwości, wskazując, że umowa nielegalna oznacza umowę, która jest niezgodna z prawem lub stusznościa, niezależnie od tego, czy niezgodność z prawem wynika z przyczyn dotyczacych jej zawarcia lub wykonania umowy; i zawiera postanowienie zawierające nielegalne postanowienie umowne, niezależnie, czy postanowienie to może zostać oddzielone od umowy, czy nie może.

Wśród najistotniejszych kwestii kontrowersyjnych, które uregulowano w 1970 r. (sekcja 5 starej ustawy) i utrzymano w mocy w 2017 r., znajduje się brak automatycznej sankcji nielegalności, jeżeli niewadliwa umowa została wykonana

\footnotetext{
92 The Law Commission, The Illegality Defence..., s. 1.

93 The British Columbia Law Institute, Report on Relief Under Legally Defective..., s. 44.

94 Tamże, s. 47.

95 Tamże, s. 44.
} 
w sposób nielegalny (por. sekcja 72 nowego prawa z 2017 r.). Taka sankcja musi jednoznacznie wynikać z przepisów. Ustawa także przewiduje ochronę dobrej wiary osób, które na podstawie nielegalnej umowy nabyły własność (sekcja 74).

Instytucję illegality reguluje się także na poziomie prawa o restytucji i bezpodstawnym wzbogaceniu. W prawie amerykańskim, w The Restatement (Third) of Restitution and Unjust Enrichment (opublikowanych w 2011 r. przez The American Law Institute) definiuje się skutki nielegalności wynikającej z naruszenia prawa lub porządku publicznego. Na mocy sekcji 32 osoba, która świadczy usługi na mocy umowy niezgodnej z prawem lub w inny sposób nieegzekwowalnej ze względów porządku publicznego może uzyskać zwrot spełnionego świadczenia od odbiorcy zgodnie z trzema następującymi zasadami:

1. Restytucja będzie dozwolona, niezależnie od tego, czy będzie konieczne, aby zapobiec bezpodstawnemu wzbogaceniu, jeżeli restytucja jest wymagana przez politykę leżącą u podstaw zakazu.

2. Restytucja będzie również dozwolona, jeśli będzie to konieczne, aby zapobiec bezpodstawnemu wzbogaceniu, jeżeli przyznanie restytucji nie przekreśli ani nie osłabi polityki leżącej u podstaw zakazu. Nie będzie stanowić bezpodstawnego wzbogacenia, jeżeli powód otrzyma świadczenie wzajemne określone przez umowę stron podlegającą nieegzekwowalności.

3. Restytucja zostanie odrzucona, niezależnie od wzbogacenia się pozwanego kosztem powoda, jeżeli roszczenie na podstawie podpunktu 2 zostanie wykluczone przez niegodne zachowanie powoda (określane zgodnie $\mathrm{z} \S 63$, tj. tzw. brak czystych rąk $\left.{ }^{96}\right)$.

Unormowanie § 63 The Restatement (Third) of Restitution and Unjust Enrichment odpowiada, pomimo pewnego przeformułowania, regule zaproponowanej w § 197-198 The Restatement (Second) of Contracts z 1981, a także rozwiązaniom prawa Nowej Zelandii.

$96 \$ 63$ [Equitable Disqualification (Unclean Hands)]: Recovery in restitution to which an innocent claimant would be entitled may be limited or denied because of the claimant's inequitable conduct in the transaction that is the source of the asserted liability. Podkreśla się, ze zaproponowana norma jest przykładem unifikacji podejścia common law i equity do zasady unclean hands. Dotyczy wszystkich rodzajów roszczeń - por. bliżej L. Smith, Common Law and Equity in R3RUE, Washington and Lee Law Review, 2011, vol. 68, s. 1198. Autor ten wskazuje m.in. na interesującą tendencję - w The Restatement (Third) of Restitution \& Unjust Enrichment (często stosowany skrót: R3RUE) próbowano określić główne normy prawa bez zachowywania rozróżnienia na common law oraz na equity - por. wraz z przywołanym tam piśmiennictwem: tamże, s. 1186-1187, s. 1193 i nn. Na temat zasady unclean hands - por. wraz z dalszym piśmiennictwem i orzecznictwem T. Leigh Anenson, Limiting Legal..., s. 63 i nn. 
W piśmiennictwie zwraca się uwagę, że przeformułowana zasada kładzie obecnie nacisk na określenie celu (policy) naruszonego zakazu ${ }^{97}$. Warte odnotowania jest, że uznaje się § 32 za rozwiązanie odpowiadające najnowszemu orzecznictwu angielskiemu, kanadyjskiemu i australijskiemu ${ }^{98}$.

Obok prac legislacyjnych coraz większe znaczenie zyskuje orzecznictwo poszukujące sankcji proporcjonalnej poprzez różne instrumenty, np. dzięki życzliwej interpretacji celu i polityki naruszonego przepisu i każdorazową ocenę, czy tak surowa sankcja jest niezbędna (the benevolent rule) ${ }^{99}$. Działanie zasady, że powód nie może czerpać korzyści ze swojego postępowania, jeżeli jest ono sprzeczne z prawem, postuluje się ograniczyć jedynie do sytuacji, gdzie w rzeczywistości powód jest osobą popełniającą czyn zabroniony, nie zaś do wszystkich przypadków naruszeń ustawy. Proponuje się także, aby zasada odstraszania przed podejmowaniem czynności bezprawnych i niemoralnych została oddana jednak sądom karnym, podobnie jak wymiar $\operatorname{kar}^{100}$. Niemniej jednak oczywiste jest, że przyznawanie zwrotu spełnionych świadczeń mogłoby podważać sens stosowania tej sankcji ${ }^{101}$.

Podsumowując: główną cechą omawianej doktryny jest silne powiązanie stanu nieważności skutków prawnych $\mathrm{z}$ brakiem dostępności roszczeń restytucyjnych $\mathrm{z}$ bezpodstawnego wzbogacenia i innych roszczeń, $\mathrm{w}$ tym o odszkodowanie ${ }^{102}$.

\subsection{Podstawowe wady uzasadniające zarzut illegality}

Podstawy (normy merytoryczne) do zarzucenia nielegalności z reguły dzieli się na nielegalność z powodu naruszenia ustaw oraz nielegalność z powodu naruszenia

97 J. King, The Doctrine of Odious Debt in International Law. A Restatement, Cambridge [Wlk. Bryt.] 2016, s. 163-164.

98 J.D. McCamus, The Restatement (Third)..., s. 454-455.

99 Por. szerzej The British Columbia Law Institute, Report on Relief Under Legally Defective..., s. 10, wraz z dalszym piśmiennictwem.

100 Tak w The Law Commission, Illegal Transactions..., s. 87-90.

101 Por. szerzej, wraz z dalszym piśmiennictwem, np. P. Birks, Recovering Value..., s. 161.

$102 \mathrm{~W}$ tym przypadku należy wskazać na rozwarstwienie pomiędzy prawem angielskim i amerykańskim, np. w prawie angielskim w ostatnich latach dominuje podejście do ujmowania restytucji w ramach bezpodstawnego wzbogacenia, gdzie podstawą roszczenia (cause of action) jest bezpodstawne wzbogacenie, zaś środkiem ochrony (remedy) restytucja - por. zamiast wielu J. Halberda, Amerykańskie prawo bezpodstawnego wzbogacenia w Restatement z 2011 r., „Kwartalnik Prawa Prywatnego” 2013, nr 4, s. 861-862; tenże, Zasada bezpodstawnego wzbogacenia, s. 92-94; tenże, Historia angielskich quasi-kontraktów a zasada bezpodstawnego wzbogacenia, „Państwo i Prawo” 2012, nr 1, s. 64 i nn. 
porządku publicznego (nieco rzadziej moralności) ${ }^{103}$. Jako jeden z przypadków nielegalności uznaje się także działanie pod wpływem błędu co do prawa ${ }^{104}$.

Istotną cechą odróżniającą tę wadliwość jest fakt, że umowa może być uznana za nielegalną zarówno z przyczyn dotyczących jej zawarcia, jak i sposobu wykonania oraz celu, w jakim została dokonana ${ }^{105}$.

Częste połączenie w wypowiedziach doktryny obu tych terminów zdaje się wynikać głównie z tradycyjnego poglądu, że termin illegal mówi także o sytuacji zbieżnej z przypadkiem sankcji nieważności ex lege. To zdaje się uzasadniać rozróżnienie w tej grupie wadliwych umów na przypadek:

- nielegalności w sensie „niezgodny z przepisami” oraz

- nielegalny w sensie „bezprawny” (unlawful) ${ }^{106}$.

Skutkiem głównym nielegalności jest wspomniany brak możliwości wywodzenia jakichkolwiek roszczeń kontraktowych oraz roszczeń o odszkodowanie ${ }^{107}$ - występuje stan nieegzekwowalności umowy w sensie formalnym procesowym i materialnym. W prawie kontynentalnym objaśnia się, że stan ten jest przypadkiem pośrednim pomiędzy sankcją nieważności bezwzględnej a sankcją wzruszalności umowy, a umowa może uzyskać skuteczność na mocy decyzji sądu ${ }^{108}$. W ramach komentarza do tego poglądu wypada zauważyć, że taka możliwość jest jednak właściwa sankcji nieegzekwowalności w przypadku naruszenia przepisów o wymaganej formie, a w przypadku illegality najczęściej nie będzie to wchodzić w rachubę. W wypowiedziach doktryny systemów common law często wobec tego faktu dodaje się termin void dla sankcji wadliwości powiązanej z nielegalnością, podkreślając jej permanentność.

Przyjmuje się w zasadzie sześć podstawowych założeń doktryny nielegalnych umów (lub innych czynności prawnych):

- dbanie o przestrzeganie celu normy naruszonej nielegalnym zachowaniem powoda (furthering the purpose of the rule which the claimant's illegal

103 The British Columbia Law Institute, Report on Relief Under Legally Defective..., s. 7. Moralność zdaje się inkorporowana w zakres pojęcia porządku publicznego. Jest to wynik akceptacji pewnej konwencji zakresów pojęciowych tych norm generalnych.

104 G.H. Treitel, The Law..., s. 214-215.

105 Por. raport The Law Commission, Illegal Transactions..., s. 114.

106 P. Gillies, Concise Contract..., s. 148.

107 Por. szerzej na temat zasad utraty roszczeń restytucyjnych i różnic pomiędzy prawnym podejściem Wielkiej Brytanii a USA, np. J. King, The Doctrine of Odious Debt..., s. 162 oraz Principles, Definitions and Model Rules of European Private Law. Draft Common Frame of Reference (DCFR). Full Edition, t. 1-6, red. Ch. Von Bar, E. Clive, [b.m.] 2009, s. 546.

108 Na podstawie wypowiedzi doktryny angielskiej, W. van Gerven, The Concept of Provisional Validity. The Doctrine of Nullity Refined [w:] Ius Privatum Gentium, Festschrift für Max Rheinstein, t. II, red. E. von Caemmerer, M. Rheinstein, S. Mentschikoff, K. Zweigert, Tübingen 1969 , s. 520 . 
behaviour has infringed), który to cel mógłby być zagrożony dopuszczeniem do zawierania i wykonywania pewnych rodzajów czynności prawnych,

- koherentność systemu środków prawnych (consistency), która to spójność byłaby naruszona, jeżeli prawo pozwoliłoby na roszczenia z tytułu bezpodstawnego wzbogacenia, a roszczenie to prowadziłoby do tego samego efektu jak roszczenie z umowy, której wykonania odmówiono przez przyjęcie jej nielegalności,

- zachowanie powagi sądów oraz integralności systemu prawnego (m.in. przez uniknięcie rozpatrywania sporów prowadzonych przez osoby naruszające i obchodzące prawo) - tzw. zasada nieinterwencji,

- przestrzeganie zasady, że powód nie może czerpać korzyści ze swojego złego postępowania,

- konieczność odstraszenia (deterrence) od zawierania lub wykonywania czynności prawnych sprzecznych z prawem. Przyjmuje się np., że taki cel polityki stosowania prawa względem nielegalnych umów jest jednym z najczęściej cytowanych argumentów przez sądy w Wielkiej Brytanii ${ }^{109}$,

- kara za naruszenia zakazów ustawy lub porządku i interesu publicznego ${ }^{110}$.

W piśmiennictwie angielskim zwrócono uwagę na konflikt pomiędzy zasadą odstraszania a zasadą odmówienia stronom rozpatrywania ich sporów z nielegalnych umów ${ }^{111}$. Wynika to z tej okoliczności, że często dopiero w trakcie sporu ujawnia się nielegalność umowy ${ }^{112}$.

Uzasadnienie odwołujące się do potrzeby zachowania powagi wymiaru sprawiedliwości sprowadza się przede wszystkim do przyjmowania z urzędu nielegalności umowy. Krąg przesłanek do przyjęcia nielegalności jest nawet określany w nauce mianem „ekstremalnie szerokiego”, ponieważ nie tylko wadliwość ta obejmuje popełnienie przestępstwa czy wykroczenia na etapie zawarcia lub wykonania umowy. Może wynikać z naruszenia przepisów ustawowych i sprzeczności z dobrymi obyczajami (również z szeroko rozumianym porządkiem publicznym), które w ogóle nie są penalizowane w materialnym prawie karnym ${ }^{113}$.

109 The Law Commission, The Illegality Defence..., s. 12.

110 Por. m.in. R. Stone, The Modern Law..., s. 351-352, The Law Commission, The Illegality Defence..., s. 8 i nn. The Law Commission, Illegal Transactions..., s. 87-90.

111 Doktryna nielegalności obejmuje także wadliwość trustów. Z tego powodu uprawnione jest odniesienie dalszych uwag również do tego rodzaju czynności prawnych. Na temat pewnych odrębności por. szerzej np. tamże, s. 50 i nn., R. Halson, Contract Law, Harlow 2001, s. 228-230. Por. omówienie nielegalności jako prawnego środka obrony przeciw roszczeniom deliktowym - The Law Commission, The Illegality Defence in Tort, „A Consultation Paper” 2001, nr 160, www.lawcom.gov.uk), passim.

112 R. Stone, The Modern Law..., s. 352.

113 W.J. Swadling, The Role of Illegality in the English Law of Unjust Enrichment [w:] Unjustified Enrichment. Key Issues in Comparative Perspective, pod red. D. Johnstona, R. Zimmermanna, Cambridge [Wlk. Bryt.] 2002, s. 289. 
W przypadku naruszenia porządku publicznego, podkreśla się, że ta ostatnia podstawa wadliwości jest tak szeroko definiowana, że staje się bezużyteczna ${ }^{114}$.

Przywołane poglądy świadczą o surowości orzecznictwa. Niektóre orzeczenia wskazują, że zagubiono w praktyce cel tej instytucji. Był to jeden z kluczowych argumentów, dla których podjęto działania legislacyjne.

W raportach komisji kodyfikacyjnych angielskiej lub kanadyjskiej, po wyczerpującym zaprezentowaniu szeregu problemów praktycznych, zaproponowano rezygnację z tradycyjnego zakresu sankcjonowania wad uzasadniających illegality. Otwarcie zarzuca się szerokiemu stosowaniu nielegalności wprowadzanie „odrażająco” niesprawiedliwych lub nielogicznych skutków dla stron umowy ${ }^{115}$.

W Anglii zaproponowano skorzystanie $\mathrm{z}$ elastycznej koncepcji sankcji sędziowskiej w wytyczeniu cech sankcji nielegalności. Głównie wskazywano jako wzór prawo Nowej Zelandii oraz amerykańskie The Restatement the Second of Contracts z $1981 \mathrm{r}$. Miało to pozwolić na zmianę tendencji orzeczniczej w celu ograniczenia nieproporcjonalnych reakcji w zakresie negatywnych skutków prawnych dla uczestników czynności prawnej (szczególnie nieodpowiadających za przyczyny nielegalności). Sankcja sędziowska została przyjęta w formie ograniczonej, jako tzw. uporząadkowana dyskrecjonalność (structured discretion), która jest konstrukcją często wykorzystywaną w common law także w prawie karnym.

W prawie angielskim po 10 latach konsultacji w roku 2009 r. zrezygnowano jednak ostatecznie w prawie umów z tej koncepcji i pozostawiono ją case law. Odmiennie los tej instytucji ukształtował się w prawie kontynentalnym: structured discretion recypowano w Common Frame of Reference i UPICC (UNIDROIT Principles of International Commercial Contracts). Obecnie po zaprzestaniu prac nad wspólnym prawem prywatnym dla UE jedynie w ujęciu punktowym nawiązuje się do takiego podejścia (jak np. w prawie polskim).

\section{§ 4. Skutki naruszenia ustawy}

\subsection{Uwagi ogólne}

Charakterystyka tej wadliwości potwierdza skomplikowanie omawianej materii. Jak zostało wspomniane, w przypadku naruszenia ustawy tradycja anglosaska przyjmuje co do zasady nielegalność umowy. Równolegle wyodrębnia się także

114 G.H. Treitel, The Law..., s. 325.

115 Por. The British Columbia Law Institute, Report on Relief Under Legally Defective..., s. 1. W raporcie podkreśla się wynikającą z tego faktu narastającą liczbę wyjątków tworzonych przez sądy w celu uniknięcia „absurdalnie niesprawiedliwych” rozstrzygnięć. 
kategorię ustawowej nieważności. Najczęściej termin „ustawowa nieważność” (statutory invalidity) odnosi się do umów lub ich poszczególnych postanowień, które są nieważne bezwzględnie, wzruszalne, nieegzekwowalne lub pod innym względem bezskuteczne z mocy ustawy, które jednak nie zawierają pośrednio lub bezpośrednio zabronionego postępowania przez prawo ${ }^{116}$.

Poglądy te pozwalają na podsumowanie, że naruszenie ustawy w common law powoduje:

- sankcję nieważności ustawowej,

- sankcję nielegalności ustawowej.

Naruszenie ustawy może być wynikiem zarówno wystąpienia przyczyn aktualnych w momencie zawierania umowy, jak też poprzez wykonanie umowy ${ }^{117}$. Podobnie jak w systemach ius civile, zaistnienie naruszenia powoduje skutki określone w samej treści przepisu albo te wynikające tylko z jej interpretacji.

Bliższe wyjaśnienie jest niezbędne do zobrazowania skomplikowania tej formy wadliwości. Obok powyższych skutków typowych, w piśmiennictwie zwraca się uwagę, że w przypadku naruszenia przepisów ustawy wprowadzonych w celu ochrony słabszej strony umowy, może zostać zastosowana sankcja wzruszalności, nie zaś nieważności bezwzględnej ${ }^{118}$. Stanowisko to wskazuje na skłonność do relatywizacji cech formalnych sankcji nieważności bezwzględnej - uzależnienia trybu jej stosowania od kryteriów celowościowych. Spotkać się z takimi poglądami można dość często w tradycji kontynentalnej ${ }^{119}$.

\subsection{Nieważność ustawowa}

Ten rodzaj sankcji nieważności (contracts rendered void by statute lub statutory invalidity) musi być wyraźnie zastrzeżony w tekście danego przepisu. W odmiennym wypadku zostanie przyjęta w drodze wykładni ostrzejsza sankcja konkurencyjna, którą jest nieegzekwowalność umowy (illegality). Wyjaśnia to wypowiedzi doktryny, że naruszenie ustawy czasem powoduje ,jedynie” nieważność umowy ${ }^{120}$.

116 The Law Commission, Illegal Transactions..., s. 5, G.H. Treitel, The Law..., s. 394.

117 R. Stone, The Modern Law..., s. 355.

118 M. Cumyn, Nullity of Contracts in Québec Law, An Overview And Comparison With The Common Law of Illegal Contracts, Uniform Law Conference of Canada, Civil Law Section, Saskatchewan 2004, http://www.ulcc.ca, s. 3, 11. Autor na uzasadnienie przywołuje orzeczenia kanadyjskiego Sądu Najwyższego: Advance Rumely Thresher Co. v. Yorga, [1926] S. C.R. 397; Dorsch v. Freeholders Oil Co, [1965] S. C.R. 670; Pinsky v. Wass, [1953] 1 S. C.R. 399, (S.C.R publikator Supreme Court Reports, http://scc.lexum.umontreal.ca/en/).

119 Por. szerzej R. Trzaskowski, Skutki sprzeczności umów obligacyjnych..., passim; R.M. Beckmann, Nichtigkeit und Personenschutz. Parteibezogene Einschränkung Der Nichtigkeit Von Rechtsgeschäften, Tübingen 1998, passim.

120 Na przykład R. Youngs, English, French and German..., s. 379. 
Sankcja nieważności działa ex tunc. Następuje przyjęcie fikcji, że nie doszło do wywołania żadnych zamierzonych skutków prawnych. W przeciwieństwie do nielegalności, w razie wykonania umowy podlegającej tej sankcji powstaje obowiązek przywrócenia stanu poprzedniego (np. dzięki temu nie może zostać także przeniesiona własność) $)^{121}$.

Zważywszy na automatyzm w przywróceniu stanu poprzedniego, jest to podejście najbliższe cechom formalnym nieważności bezwzględnej w prawie polskim. Dostępność roszczeń restytucyjnych w przypadku nieważnych bezwzględnie (void) przyjmowano również $\mathrm{w}$ założeniach reformy nielegalnych umów $\mathrm{w}$ prawie angielskim ${ }^{122}$.

W prawie angielskim wyróżnia się w ramach ww. kategorii głównie dwa rodzaje nieważnych bezwzględnie umów, które nie są jednocześnie objęte sankcją nielegalności (nieegzekwowalności):

- w przypadku umów naruszających zasady przyjmowania zakładów lub gier $^{123}$. Nie są one generalnie uznawane za należące do kategorii umów nielegalnych, ponieważ ustawa nie zawiera żadnego zakazu gier lub zakładów $^{124}$;

- umowy naruszające przepisy chroniące wolną konkurencję. W prawie angielskim podstawa tej sankcji nieważności zawarta jest zarówno w ustawie ${ }^{125}$, jak i obecnie wynika z prawa UE, tj. art. 101 Traktatu o Unii Europejskiej i Traktatu o Funkcjonowaniu Unii Europejskiej ${ }^{126,127 .}$

Cechom sankcji nieważności bezwzględnej odpowiada także wadliwość związana z zawarciem umowy pod wpływem istotnego błędu oraz w przypadku braku zdolności do czynności prawnych, w tym działania ultra vires ${ }^{128}$.

121 G.H. Treitel, The Law..., s. 19.

122 Por. szerzej The Law Commission, Illegal Transactions..., s. 124-126.

123 Obecnie zagadnienia ważności takich umów reguluje Gambling Act 2005. Ustawa ta zawiera m.in. możliwość wydawania orzeczeń przez komisję nadzorującą wykonanie ustawy, powodujących nieważność bezwzględną umów i porozumien dotyczących zabronionego zakładu oraz konieczność zwrotu pieniędzy - por. sekcja 336 Gambling Act 2005.

124 Por. m.in. tamże, s. 6.

$125 \mathrm{~W}$ prawie angielskim reguluje obecnie tę kwestię w sposób kompleksowy Competition Act 1998, który uchylił w 2000 r. dotychczasowe regulacje, rozmieszczone w 4 różnych aktach prawnych (były to: The Restrictive Practices Court Act 1976, The Restrictive Trade Practices Act 1976, The Resale Prices Act 1976, the Restrictive Trade Practices Act 1977).

126 Art. 101 TUEU to dawny art. 81 Traktatu Wspólnot Europejskich, a pierwotnie art. 85 Traktatu Rzymskiego.

127 G.C. Cheshire, C.H. Fifoot, M. Furmston [w: Law of Contract, s. 328-333; R. Halson, Contract..., s. 214-216.

128 Tak m.in. E.A. Kramer [w:] International Encyclopedia of Comparative Law. Volume VII. Contracts in General, red. K. Zweigert, U. Drobnig, Tübingen 1981, s. 48; S. Erbacher, Australian Restitution Law, wyd. 2, Cavendish 2002, s. 368. Warto zauważyć, że także ta Autorka określa nieważność (void) jako sytuację, gdy umowa nigdy nie uzyskała bytu prawnego. 
Zastosowanie nieważności bezwzględnej przyjmuje się także w sytuacji zawarcia umowy $z$ przekroczeniem pełnomocnictwa, jeżeli mocodawca nie potwierdzi umowy lub nie będzie związany umową na zasadzie tzw. oczywistego lub rzekomego pełnomocnictwa. Zawarcie umowy z osobą bez umocowania lub z przekroczeniem jego zakresu uprawnia do odszkodowania równego wartości utraconych korzyści. Stanowi to podstawę do uzyskania zwrotu spełnionego świadczenia wedle przepisów o bezpodstawnym wzbogaceniu ${ }^{129}$. Jest to rozwiązanie analogiczne do polskiej konstrukcji bezskuteczności zawieszonej i skutku braku potwierdzenia, tj. doprowadzenia do stanu nieważności ab initio.

Skutki sankcji nieważności bezwzględnej i restytucja z tytułu bezpodstawnego wzbogacenia kształtują się raczej dość skomplikowanie.

Generalną zasadą jest, że rozstrzygające znaczenie ma brzmienie naruszonej ustawy, a w razie braku unormowania sankcji, stosuje się zasady prawa powszechnego (common law) ${ }^{130}$.

Możliwość zwrotu świadczenia spełnionego na podstawie nieważnej umowy zachodzi na podstawie następstwa całkowitego upadku przyczyny umowy (failure of consideration); ze względu na nieistnienie umowy uznaje się to za „upadek zamierzonej przyczyny zawarcia umowy”. Alternatywnie przyznaje się roszczenie wg przepisów o skutku błędu odnośnie do ważności umowy ${ }^{131}$. Wyjaśnia się przy tym, że w ramach roszczenia restytucyjnego o zwrot bezpodstawnego wzbogacenia specjalny środek prawny (do odzyskania spełnionego świadczenia lub jego wartości) jest nieco myląco określany mianem „upadku przyczyny świadczenia”, ponieważ bardziej przydatne jest określenie „upadek podstawy prawnej" (failure of basis) ${ }^{132}$.

Jednak nie jest to podejście powszechnie przyjęte. Tytułem przykładu można wskazać, że skutki nieważności na przykładzie umów naruszających zasady przyjmowania zakładów lub gier definiowane są w ten sposób, że nie jest w zasadzie dopuszczalne powództwo o wykonanie umowy lub odzyskanie spełnionych świadczeń (ale w przypadku dokonania płatności przyjmuje się, że uchyla ona zastosowanie ustawy ${ }^{133}$ - jest to jeden z konwalidacyjnych przykładów doniosłości wykonania zobowiązania).

129 Por. P.D. Maddaugh, J.D. McCamus, The Law of Restitution, Aurora [Ontario] 2004, s. 16-1 wraz z przywołanym tam dalszym piśmiennictwem.

130 Ch. Turner, Key Facts..., s. 182.

131 Tak w prawie australijskim S. Erbacher, Australian Restitution..., s. 368-369.

132 P. Birks, Recovering Value Transferred..., s. 156, 161, K. Raghavan, Failure of Consideration as a Basis for Quantum Meruit Following a Repudiatory Breach of Contract, „Monash University Law Review” 2016, vol. 42, iss. 1, s. 180.

133 Ch. Wild, S. Weinstein, Smith and Keenan's English Law, wyd. 14, Harlow 2004, s. 368, G.C. Cheshire, C.H. Fifoot, M. Furmston [w: ] Law of Contract, s. 307-309. 
Wyjątkiem w tym zakresie jest przyznanie, na gruncie equity, ważności (wykonalności) umowy dla zwycięzcy, jeżeli gra lub zakład nie wyczerpywała znamion nielegalności ${ }^{134}$.

Skutki stanu nieważności umowy rozciągają się na wydawane w zamian wypłaty pieniężnej papiery wartościowe. Jedynym wyjątkiem jest nabycie papieru wartościowego przez osobę, która nie działała w świadomości nielegalnego pochodzenia papieru wartościowego ${ }^{135}$. Ciężar dowodu spoczywa na osobie trzeciej. Zasięg nieważności rozciąga się także na pożyczki udzielone w celu zawierania nielegalnych gier lub zakładów, które nie mogą zostać odzyskane ${ }^{136}$.

Należy wobec powyższego zaznaczyć, że umowy podlegające „wyłącznie” sankcji nieważności bezwzględnej odróżnić można od przypadków nielegalnych umów wedle kryterium zasięgu następstw tych sankcji wadliwości. Najważniejsze różnice dotyczą następujących kwestii:

- jako zasadę przyjmuje się - w przypadku umów nielegalnych - wyłączenie tzw. sankcji częściowej nieważności, co następuje przez ograniczenie możliwości oddzielenia nieważnego postanowienia umowy na mocy kryteriów ujętych zbiorczo w przesłankach częściowej nieważności (severance); natomiast przyjmuje się dopuszczalność takiego zabiegu dla umów podlegających sankcji nieważności bezwzględnej,

- w przypadku nieważności bezwzględnej przysługują roszczenia o zwrot uzyskanych korzyści wedle przepisów o bezpodstawnym wzbogaceniu, w przypadku umów nielegalnych jest to wówczas możliwe wyłącznie, jeżeli powód nie był współodpowiedzialny za przyczynę nielegalności (zagadnienie to jest nieco bardziej skomplikowane i w niektórych aspektach zostanie przybliżone poniżej),

- zakres sankcji nieważności bezwzględnej co do zasady nie obejmuje tzw. powiązanych lub podporządkowanych umów; w przypadku nielegalności takie dalsze umowy również są pozbawione wykonalności prawnej, tj. zamierzonych skutków prawnych; nielegalność rozciąga się co do zasady na całość skutków prawnych towarzyszących nielegalnej umowie (czynności prawnej),

- nieważna umowa spółki cywilnej może wywoływać skutki prawne pomiędzy stronami, co jest wykluczone w przypadku nielegalności,

- bezwzględnie nieważne umowy wobec niezachowania szczególnej formy (deed under seal), mogą zachować skutki prawne (wykonalność) ${ }^{137}$.

134 Tamże, s. 311-312; G.H. Treitel, The Law..., s. 400-403.

135 Por. szerzej J. Beatson, Anson's Law..., s. 333-345.

136 Tamże, s. 346-347; G.C. Cheshire, C.H. Fifoot, M. Furmston [w: ] Law of Contract, s. 321 .

137 Por. N.J. Thompson, The Rights of Parties..., s. 7-8, wraz z przywołanym dalszym orzecznictwem. 


\subsection{Nieważność na gruncie prawa powszechnego (common law) - ogólna systematyka ${ }^{138}$}

Poniżej podane naruszenia wypracowano w orzecznictwie prawa powszechnego (common law). W dalszych uwagach niezbędne jest wyjaśnienie, że w tym przypadku termin common law odnosi się do systemu orzecznictwa w przeciwieństwie do systemu orzekania na podstawie reguł słuszności (equity), który sprawowany był przez Sąd Kanclerski (The Court Of Chancery), będący głównym administratorem tego systemu. Dualizm ten obowiązywał aż do czasu reform związanych $\mathrm{z}$ uchwaleniem The Judicature Acts 1873-75, gdy wraz z powołaniem High Court of Justice dokonano połączenia jurysdykcyjnego obu systemów common law oraz equity. Nie dokonano jednak likwidacji orzekania wedle zasad słuszności, które sprawowane jest obecnie przez Wydział Kanclerski (the Chancery Division), wchodzacy w skład the High Court of Justice ${ }^{139}$.

Powszechnie wyróżniane w common law podstawy tej odmiany wadliwości to:

1. umowy wyłączające jurysdykcję sądów (Contracts ousting the jurisdiction of the courts),

2. umowy podważające instytucję małżeństwa (Contracts undermining the institution of marriage),

3. umowy mające na celu rezygnację z odpowiedzialności rodzicielskiej (Contracts to relinquish parental responsibility),

4. umowy w zakresie ograniczania handlu (Contracts in restraint of trade $)^{140}$.

Skutki nieważności w prawie powszechnym co do zasady mają dotykać wyłącznie wadliwe postanowienia umowy, jeżeli takie utrzymanie w mocy umowy będzie możliwe, zgodnie z zasadami stosowania nieważności częściowej $\mathrm{w}$ ramach instytucji severance ${ }^{141}$.

Sposoby sankcjonowania powyższych naruszeń zostaną omówione poniżej, ponieważ nie są one zawsze rozpoznawane jednolicie w common law, i wydaje się, że właściwszym sposobem jest omówienie ich na tle skutków niezgodności $\mathrm{z}$ public policy.

138 Bliżej podstawy tej sankcji zostaną omówione w kontekście sprzeczności z public policy w pkt 8, poniżej.

139 Por. szerzej B. Więzowska, Odpowiedzialność cywilna na zasadzie stuszności, Warszawa 2009, rozdział II, pkt 4.1 .

140 Takie przyczyny wskazuje, wraz z powołanym wiodącym orzecznictwem, Ch. Turner, Key Facts..., s. 182.

141 Nieważność częściowa i severance zostanie umówiona w dalszych uwagach. 


\section{§ 5. Sankcja nielegalności ustawowej oraz nielegalności na gruncie prawa powszechnego (common law)}

\subsection{Sankcja nielegalności ustawowej (contracts illegal by statute, contracts rendered unenforceable by statute; statutory illegality)}

Wyróżnia się dwojakie umocowanie tej sankcji; może wynikać bezpośrednio i wyraźnie z zakazu ustawy (doktryna angielska terminem ustawa obejmuje także inne akty prawne wydawane na mocy upoważnienia parlamentu $)^{142}$ lub zostać przyjęta w sposób dorozumiany poprzez wykładnię ustawy. Wówczas sąd musi zdecydować, czy ustawa zabrania danej umowy i czy taka była intencja danego zakazu ${ }^{143}$. Dopełnieniem takiej kategorii naruszenia jest wyróżnienie także odmiany umów nielegalnych z powodu tzw. public policy, a także umowy nielegalne wskutek naruszeń ustawy sposobem wykonania zobowiązania ${ }^{144}$.

Zastosowanie sankcji sąd powinien poprzedzić rozważeniem, czy sankcja unenforceable ma być skierowana przeciwko roszczeniom jednej czy obu stron ${ }^{145}$. Stosunkowo mniej problemów łączy się z wyraźnym zakazem wynikającym z danego przepisu, którego naruszenie prowadzi do niezaskarżalności umowy wskutek nielegalności. Jednak właściwie dla tradycji common law przyjęto także, poprzez wypracowanie kilku reguł w orzecznictwie, wspomnianą koncepcję dorozumianego zakazu ustawowego (implied statutory prohibition). Zagadnienie to nasuwa bliskie skojarzenia z przyjmowaniem w prawie polskim szerokiego rozumienia zwrotu „obejście ustawy” na gruncie aktualnego art. $58 \mathrm{KC}$. Tym samym istnienie tak sankcjonowanego zakazu przyjmuje się, jeżeli ustawa zabrania zawarcia lub wykonania umowy (explicite lub w sposób dorozumiany).

\subsection{Koncepcja dorozumianego zakazu ustawowego w common law}

Podkreśla się w tym przypadku, że sprzeczność z ustawą obok sytuacji jednoznacznych, może polegać również na naruszeniu celu lub polityki (ratio legis) danego przepisu ${ }^{146}$. Brzmi to jak wyjaśnienie założeń kontynentalnej doktryny agere in fraudem legis.

142 G.C. Cheshire, C.H. Fifoot, M. Furmston [w: ] Law of Contract, s. 334.

143 Tak m.in. E. McKendrick, Contract..., s. 290; P. Gillies, Concise Contract..., s. 148. Należy w ramach kolejnej dygresji o terminologii zaznaczyć, że ten ostatni autor używa w zasadzie jedynie terminu void zamiast unenforceable lub illegal.

144 Ch. Turner, Key Facts..., s. 177.

145 The Law Commission, The Illegality Defence..., s. 18.

146 The British Columbia Law Institute, Report on Relief Under Legally Defective..., s. 8-9. 
Odnotowania wymaga trafna diagnoza sformułowana w celu wskazania źródła problemu zarzutów naruszenia ustaw lub innych wymogów prawnych; zwraca się w nauce podobnie jak w ius civile uwagę na przyczynę nielegalności, tj. rosnące nasycenie obrotu prawnego regulacjami. To zaś skłania do postulowania odejścia od tradycyjnie wypracowanych formuł reagowania na niezgodność $z$ przepisami prawa ${ }^{147}$. Orzecznictwo także zwraca na to uwagę, że naruszenie przepisów może nastąpić dość łatwo, nawet bez niewłaściwych zamiarów ${ }^{148}$.

Podobnie jak w poprzednim przypadku, ta forma nielegalności może wynikać z naruszeń aktualnych w chwili zawarcia umowy. Może też wynikać z nielegalnego sposobu wykonania umowy (najczęściej wskutek złamania przepisów branżowych, różnych wymogów regulacyjnych czy wreszcie popełnienia pospolitych wykroczeń lub przestępstw przy okazji wykonania zobowiązań). Ten przypadek jest określany tzw. następczą nielegalnością (supervening illegality) ${ }^{149}$.

Szczególnej rozwagi wymaga postawienie zarzutu naruszenia ustawy wyłącznie w drodze wykładni danej merytorycznej normy. Rezultat wykładni jest kreowany przede wszystkim uwzględnieniem celu ustawy i rodzaju chronionego dobra oraz jego związku z przedmiotem umowy. Proces wnioskowania opiera się przy tym na przesądzeniu, czy okoliczności dotyczące zawarcia umowy i jej celu albo dotyczące umówionego sposobu jej wykonania zawierają złamanie przepisu ustawy, i czy należy sankcjonować to niezaskarżalnością umowy przez jedną czy też obie strony ${ }^{150}$.

Asumpt do przyjęcia wniosku o dorozumianej nielegalności może wynikać z tej okoliczności, że na etapie wykonania umowy pewne zachowania stron mogą podlegać wspomnianej penalizacji w prawie karnym, prawie wykroczeń lub sankcji administracyjnej, albo też naruszać wymogi regulacyjne ograniczające swobodę umów poprzez obowiązek uzyskania licencji lub zezwolenia (regulatory statute $)^{151}$.

Koncepcja dorozumianego zakazu ustawowego jest w wielu punktach zbieżna $\mathrm{z}$ założeniami koncepcji czynności in fraudem legis wg tradycji kontynentalnej.

147 Por. P. Birks, Recovering Value Transferred..., s. 160.

148 Sprawa St John Shipping Corp v. Joseph Rank Ltd [1957]; por. również The Law Commission, The Illegality Defence..., s. 19-21.

149 Tak m.in. G.C. Cheshire, C.H. Fifoot, M. Furmston [w:] Law of Contract, s. 337; R. Halson, Contract..., s. 149.

150 Raport The Law Commission, Illegal Transactions..., s. 12 wraz z bogatym orzecznictwem i odrębnymi poglądami co do szczegółowych założeń stosowania tej sankcji wadliwości w wyniku wyinterpretowania dorozumianego zakazu. Por. także G.C. Cheshire, C.H. Fifoot, M. Furmston [w: ] Law of Contract, s. 335-337.

151 The British Columbia Law Institute, Report on Relief Under Legally Defective..., s. 10. 
Doktryny poszczególnych krajów tradycji common law kazuistycznie podeszły do problemu, kiedy należy uznać umowę za naruszającą zakaz ustawowy, jeżeli nie wynika to wprost z treści przepisu. Dorozumiana nielegalność jest przyjmowana głównie w przypadku naruszenia przepisów, które mają na celu ochronę interesu publicznego, niekiedy dość szeroko definiowanego, jako ochronę społeczeństwa przed naruszeniami określonych przepisów ${ }^{152}$. Klarowność tego typu poglądów burzy jednak okoliczność, że orzecznictwo dopuszcza także ad casum wyjątki. Utrzymuje się bowiem w mocy umowy, jeżeli możliwe jest przyjęcie, że wystarczająca będzie sankcja karna, nawet jak ustawa ma realizować określone cele ochronne o charakterze ogólnospołecznym i gospodarczym ${ }^{153}$.

Kolejną przesłanką przypisania ww. wadliwości jest ustalenie w drodze wykładni, czy ustawa w ogóle zabrania pewnego typu działalności gospodarczej, której to postanowienia narusza umowa, czy zabrania jedynie konkretnej umowy.

Problem ten stanowił kanwę orzeczeń utrzymujących w mocy umowy zawierane, np. przez banki z naruszeniem przepisów regulujących działalność bankową lub innych instytucji finansowych. Głównym argumentem za odrzuceniem zarzutu nielegalności umowy i sankcji niezaskarżalności było wskazanie na wymiar społeczny i makroekonomiczny: naruszenie interesów wszystkich klientów banku. Poprzez uznanie jednej umowy za objętą dorozumianym zakazem ustawowym, skutki obejmowały resztę umów zawieranych w zakresie działalności banku, np. o przyjmowanie lokat i depozytów bankowych. Orzecznictwo podkreśliło, że tego na pewno nie zamierzano uczynić wprowadzeniem określonych ograniczeń w prawie publicznym ${ }^{154}$. Judykatura zwróciła trafnie uwagę, że interesowi publicznemu lepiej służy ograniczanie się do unieważniania transakcji wyłącznie z poważnych powodów. Nie należy odmawiać prawa do sądu, jeżeli lepszym rozwiązaniem będzie zastosowanie sankcji karnych ${ }^{155}$.

Alternatywnym podejściem do oceny skutków naruszenia jest również analiza ex post pozycji strony, która poprzez złamanie wyraźnych lub

152 Por. np. The Law Commission, Illegal Transactions..., s. 15.

153 Tamże, s. 15 w odniesieniu do wyroku High Court of Australia z 13 maja 1997 r.; Fitzgerald v. F.J. Leonhardt Pty [1997, 189 CLR 215], http://www.austlii.edu.au.

154 Por. tamże, s. 16-17, wraz z powołanym tam dalszym orzecznictwem sądów. Wiodącym orzeczeniem jest wyrok High Court of Australia z 2.11.1978 r., Yango Pastoral Company Pty Ltd v. First Chicago Australia Ltd (1978) 139 CLR 410, http://www.austlii.edu.au. $\mathrm{W}$ tej sprawie klient banku odmówił zapłaty z tytułu długu hipotecznego, twierdząc, że bank nie otrzymał ustawowego upoważnienia wymaganego dla działalności bankowej, stąd hipoteka jest objęta dorozumianym zakazem ustawowym. Klient przegrał proces z ww. przedstawionych powodów. Należy wskazać również, że czasem przepisy danego aktu prawnego wprost regulują, że naruszenie warunków, np. prowadzenia działalności na rynku finansowym, nie powoduje nieważności lub nieegzekwowalności umów - tak w prawie angielskim, np. Sekcja 20 (pkt 2)

(b) Financial Services and Markets Act 2000.

155 G.C. Cheshire, C.H. Fifoot, M. Furmston [w: ] Law of Contract, s. 338-339. 
dorozumianych zakazów ustawowych straci wszelkie środki ochrony prawnej. To ostatnie uznaje się zasadnie za niepożądane i prowadzące do niesprawiedliwych rezultatów szczególnie, jeżeli nastąpiło mniejsze wykroczenie przeciwko przepisom, których jest w działalności gospodarczej bardzo wiele ${ }^{156}$. Ilustracją tego poglądu jest np. sytuacja, gdy niezgodność z prawem polega na dostawie towarów bez wymaganych dokumentów, gdzie stosowanie sankcji niezaskarżalności byłoby aktem niesprawiedliwym i grożącym poważną szkodą w razie jednostronnego wykonania umowy.

Doktryna postuluje często celowość ograniczenia sankcji wyłącznie do sankcji karnej. Strona odpowiedzialna za naruszenie przepisów regulujących sposób jej wykonania może dzięki temu dochodzić roszczeń z umowy ${ }^{157}$.

W piśmiennictwie australijskim przyjmowana jest szczególna postać tzw. nieważności jednostronnej podmiotowej w odniesieniu do osoby, która wiedziała o przyczynie nielegalności w chwili zawarcia umowy, tj. przeciwko jednej ze stron. Obok takiej „podmiotowej” nieważności częściowej, przyjmuje się zasadniczo także możliwość zastosowania ogólnych reguł nieważności częściowej (severance) $)^{158}$.

Podobnie w doktrynie angielskiej wskazano, że w sytuacji dorozumianego zakazu ustawowego może powstać przypadek jednostronnej nieegzekwowalności umowy ${ }^{159}$. W tym przypadku wadliwość ta sprawia, że dla drugiej strony jest zachowana ważność i skuteczność umowy ${ }^{160}$.

Interesujące dla zagadnienia proporcjonalizacji sankcji jest rosnące znaczenie zasady życzliwej reguły interpretacji w prawie kanadyjskim (Benevolent Rule of Interpretation). Źródłem tej reguły jest orzeczenie w sprawie St John Shipping Corp v. Joseph Rank Ltd. Spór toczył się wskutek odmowy zapłaty za dostawę towaru, przysługującej stronie, która została ukarana za przeładowanie statku użytego do jego transportu. Umowa w żaden sposób nie była wadliwa. Nie regulowała przy tym zobowiązań, które można byłoby powiązać z przeładowaniem statku. Sąd uznał roszczenie o zapłatę. W ocenie sądu decydujące dla zarzutu nielegalności umowy znaczenie ma okoliczność, czy cel i uzasadnienie (policy) naruszonej ustawy w ogóle zabrania danego typu umów ${ }^{161}$.

Doktryna zwraca uwagę, że the benevolent rule wymaga jedynie ustalenia dowodowego, czy może być oddzielona wadliwa klauzula, aby utrzymać w mocy czynność prawną niezależnie, czy niezgodność z ustawą dotyczy przesłanek

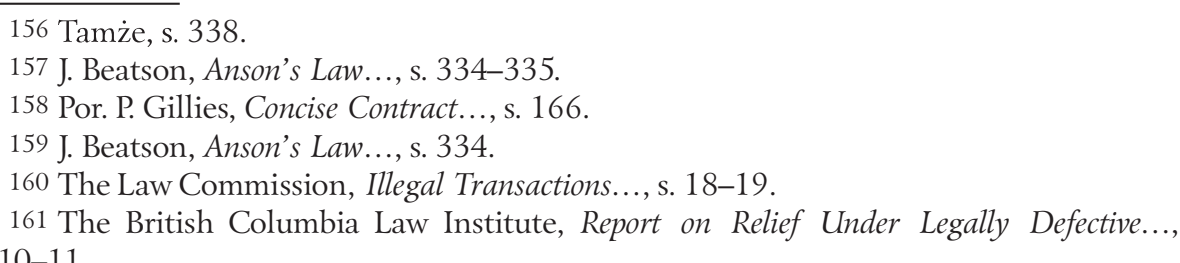
s. iii, 10-11. 
ważnego zawarcia umowy, przesłanek określenia zakresu dopuszczalnej treści lub wynikało ze sposobu wykonania umowy ${ }^{162}$.

Ten trafny postulat odrzucania skrajnych przypadków sankcjonowania umów za tego typu naruszenia odnosi się głównie do naruszeń prawa na etapie wykonania umowy, w mniejszym stopniu naruszeń zasad zawierania i determinowania treści umów. Reguła życzliwej interpretacji wymaga, by fundamentalne założenia danego przepisu prawnego: ratio legis i cel ustawy były każdorazowo analizowane do określenia, czy dla zachowania założeń ustawy niezbędne jest odmówienie wykonalności umowie ${ }^{163}$.

\subsection{Sankcja nielegalności na gruncie prawa powszechnego (contracts illegal at common law)}

Podstawy do zarzucenia nielegalności wypracowane w orzecznictwie grupuje się najczęściej w następujący sposób: ogólne naruszenie swobody umów, umowa o popełnienie przestępstwa, czynu niedozwolonego lub oszustwa, umowa o korzyści z przestępstwa innej osoby, umowa w celu popełnienia oszustw podatkowych lub innych, mająca na celu korupcję w życiu publicznym, umowy z naruszeniem prawa obcego lub ingerencji w wymiar sprawiedliwości, umowy naruszające prawa podmiotowe, umowy mające na celu promowanie niemoralności seksualnej, umowy prima facie zgodne $\mathrm{z}$ prawem, ale zawarte $\mathrm{w}$ nielegalnym celu $^{164}$. Norma sankcjonująca to nieegzekwowalność (unenforceable), podobnie jak w innych przypadkach połączona jest $\mathrm{z}$ utratą możliwości przywrócenia stanu poprzedniego oraz utratą innych potencjalnych roszczeń.

Podobnie jak w poprzednim przypadku, te naruszenia i sprzężone $\mathrm{z}$ nimi następstwa kreowane normą sankcjonującą unenforceable, nakładają się na typologię wadliwości opartą na badaniu następstw naruszenia porządku publicznego ( public policy), czy precyzyjniej to ujmując, na podstawie oceny ich katalogu norm pozaustawowych.

\subsection{Sprzeczność z wartościami pozaustawowymi (public policy)}

Sprzeczność z wartościami pozaustawowymi z reguły rozpatruje się na gruncie zbiorczej kategorii naruszenia zasad polityki i porządku publicznego (public policy). Zakres pojęciowy tej klauzuli generalnej jest bardzo szeroki

162 Tamże, s. iii, 12.

163 The Law Commission, The Illegality Defence, s. 11-12.

164 Ch. Turner, Key Facts..., s. 181. 
i zróżnicowany. W pewnym uproszczeniu można uznać, że termin ten obejmuje zarówno zasady składające się na pojęcie dobrych obyczajów: normy moralne, jak i wąsko rozumianą klauzulę porządku publicznego. Rozumienie zakresu tej klauzuli jest uzależnione od zmieniających się zwyczajów społecznych, moralności i warunków ekonomicznych; elastyczność ma umożliwiać uzasadnienie nieważności umowy przez sędziego ${ }^{165}$. Jest to wyraz klasycznej funkcji realizowanej przez klauzule generalne, odpowiadający w tym sensie podejściu ius civile.

W orzecznictwie postuluje się często ostrożność ze względu na niebezpieczeństwo tak rozumianego zakresu treściowego klauzuli. Postuluje się wstrzemięźliwość w stosowaniu tego zarzutu; aby sądy nie tworzyły nowych zasad porządku publicznego, ponieważ może to naruszać w szczególności pewność prawa. Podkreśla się, że w ostatnich latach następuje łagodzenie surowego orzecznictwa - nastawienie sądów prezentuje częściej kompromis pomiędzy elastycznością, nieodłącznie związaną z pojęciem porządku publicznego, a postulatem zapewnienia pewności prawa. Szczególną ostrożność nakazuje się w przypadku stosowania powyższych zasad do umów, które do tej pory nie były uznawane za obowiązujące, a prymat pozostawiony był ogólnym zasadom ich ważności ${ }^{166}$. Podkreśla się, że nowa zasada, wchodząca w skład pojęcia porządku publicznego, może być rozpoznana przez sąd na podstawie przedłożonych dowodów czy własnych ustaleń wynikających z nowego typu społecznych stosunków ${ }^{167}$.

Rodzaje poszczególnych naruszeń prowadzą do wyróżnienia głównych typów umów nielegalnych ze względu na naruszenie poniższych wartości lub dóbr prawnie chronionych, bądź też ogólnie pojmowanej kategorii porządku publicznego. Najczęściej wyróżnia się umowy:

1. naruszające zasady wolnej konkurencji i działalności handlowej (w tym prawo UE) ${ }^{168}$,

2. zawarte w celu popełnienia przestępstwa (np. oszustwa) lub deliktu,

165 G.H. Treitel, The Law..., s. 366; G.C. Cheshire, C.H. Fifoot, M. Furmston [w:] Law of Contract, s. 345.

166 Por. szerzej np. G.H. Treitel, The Law..., s. 366-369 oraz cytowane tam wypowiedzi sądów.

167 The British Columbia Law Institute, Report on Relief Under Legally Defective..., s. 8.

168 Tak w łącznym ujęciu wypowiedzi G.C. Cheshire, C.H. Fifoot, M. Furmston [w:] Law..., s. 344 oraz J. Beatson, Anson's Law..., s. 348-381, G.H. Treitel, The Law..., s. 326369, P. Richards, Law..., s. 284. W odniesieniu do sankcji za naruszenie przepisów TWE dotyczących ochrony wolnej konkurencji, tj. art. 81 i nn. TWE (dawny art. 85, obecny art. 101 Traktatu o Unii Europejskiej i Traktatu o funkcjonowaniu Unii Europejskiej) przewidywał czasową nieważność bezwzględną, ponieważ wadliwość może być usunięta przez uzyskanie zgody władz UE - tak G.H. Treitel, The Law..., s. 366. Należy dodać, że w trybie i na mocy przesłanek (jak się wydaje dających dość duży luz decyzyjny) art. 81 ust. 3 w zw. z art. 83 TWE dopuszczał brak nieważności bezwzględnej. Charakter tego wyjątku jest zbliżony do konwalidacji, choć poprawniej należałoby przyjąć, że przepis ten nie znajduje zastosowania i dzięki temu nie można stosować sankcji. 
3. niemoralne z powodów seksualnych,

4. szkodzące bezpieczeństwu publicznemu,

5. szkodzące wymiarowi sprawiedliwości,

6. mające na celu korupcję w życiu publicznym,

7. mające na celu defraudacje podatkowe,

8. wykluczające bezwzględnie jurysdykcję sądów w znaczeniu możliwości rozpoznania sporu $z$ danej umowy (nie obejmuje to zapisu na sąd polubowny lub o wyłączną właściwość obcego sądu ${ }^{169}$ ),

9. naruszające status moralny i prawny małżeństwa lub życia rodzinnego (prawa i obowiązki małżonków),

10. zwalniające z obowiązków rodzicielskich,

11. sprzeczne z dobrymi obyczajami,

12. ograniczające wolności osobiste ${ }^{170}$.

Wyróżnia się także umowy naruszające interes państwa i godzące w interes rządu, w szczególności przez oferowanie korzyści w zamian za określone głosowanie w parlamencie. Umowy skierowane przeciwko powadze administracji publicznej (dotyczące sprzedaży urzędów lub godności honorowych), a także naruszające zasady sprawowania wymiaru sprawiedliwości i prowadzenia procesów sądowych ${ }^{171}$.

W raporcie angielskiej komisji kodyfikacyjnej zastosowano bardziej zagregowany podział przyczyn skutkujących niezaskarżalnością umów wskutek nielegalności:

1. umowy mające na celu popełnienie czynu prawnie niewłaściwego (niedozwolonego) lub zawierające postępowanie w inny sposób naruszające zasady lub interes publiczny,

2. umowy, w których jedna ze stron lub obie zawierają umowę w celu popełnienia czynu prawnie niewłaściwego lub zawierające postępowanie w inny sposób naruszające zasady lub interes publiczny,

3. umowy, w których obie strony popełniają czyn prawnie niewłaściwy lub czynność w inny sposób naruszającą zasady lub interes publiczny ${ }^{172}$.

169 Por. np. J. Beatson, Anson's Law..., s. 358-359; P. Richards, Law..., s. 281.

170 J. Beatson, Anson's Law..., s. 356.

171 Por. tamże, s. 356, G.H. Treitel, The Law..., s. 344, P. Gillies, Concise Contract..., s. 151-153, R. Halson, Contract..., s. 206-209.

172 The Law Commission, Illegal Transactions..., s. 21-26; The Law Commission, The Illegality Defence..., s. 21. 


\subsection{Efekt nielegalności w zakresie egzekwowalności umowy oraz restitutio in integrum a proporcjonalność normy sankcjonującej i model sankcji sędziowskiej}

Sankcja przypisana nielegalności powoduje, że umowa traci możliwość wywołania zamierzonych skutków prawnych. Jednak nie ogranicza się to wyłącznie do skutków prawnych zamierzonych (lub skutków przypisywanych z mocy prawa) zawarciu umowy. Sankcja eliminuje, jak wspomniano, odzyskanie spełnionych świadczeń oraz ewentualne roszczenia odszkodowawcze ex delicto. Brak prawa do sądu co do zasady powoduje całkowitą niemożliwość przywrócenia stanu poprzedniego.

Pierwszy skutek w zasadzie odpowiada rozwiązaniom ius civile, zarówno gdy stan nieważności jest efektem sankcji nieważności bezwzględnej, jak i efektem zastosowania pozostałych sankcji wadliwości. Natomiast w common law brak roszczeń z tytułu bezpodstawnego wzbogacenia powoduje, że cechy formalne sankcji ulegają znacznemu rozbudowaniu w stosunku do ius civile. Stanowisko prawa kontynentalnego, w tym prawa polskiego, jest tutaj nacechowane większą prostotą wskutek odrębnego reżimu rozpatrywania skutków prawnych nielegalności (w prawie polskim w ramach umów o tzw. świadczeniu niegodziwym) ${ }^{173}$.

Następstwa nielegalności z powodu braku możliwości przywrócenia stanu poprzedniego prowadzić mogą do niesprawiedliwości rozstrzygnięć i utrwalenia nielegalności wskutek braku skargi o zwrot bezpodstawnego wzbogacenia i przywrócenie stanu poprzedniego. Usprawiedliwia się to ogólnymi założeniami tej instytucji, podstawowymi dla anglosaskiej koncepcji wymiaru sprawiedliwości, w myśl której sądy co do zasady odmawiają rozpatrywania roszczeń z nielegalnych umów ${ }^{174}$.

Nieproporcjonalne do skali naruszenia, zwyczajnie surowe, a drakońskie w swych następstwach podejście budzi szereg wątpliwości i powoduje wypracowywanie $\mathrm{w}$ orzecznictwie reguł osłabiających szczególnie niesprawiedliwe następstwa tej normy sankcjonującej. Wśród głównych zarzutów wskazuje się także na niepewność prawną, która wynika z możliwości stosowania sankcji w nawet najbardziej trywialnych przypadkach naruszenia przepisów lub poprzez koncepcje dorozumianego zakazu ustawowego ${ }^{175}$. Fakt nielegalności ze względu na przyczynę istniejącą w chwili dokonywania czynności prawnej jest uwzględniany przez sąd z urzędu, jeżeli nawet pozwany nie powołał się na nielegalność

173 Por. szerzej na temat stanowiska prawa polskiego, np. P. Księżak, Bezpodstawne wzbogacenie. Art. 405-414 KC Komentarz, Warszawa 2007, passim; tenże, Świadczenie niegodziwe, Warszawa 2007, passim.

174 The Law Commission, Illegal Transactions..., s. 81-82.

175 Por. uzasadnienie dla podjęcia reformy skutków nielegalności umów i trustów w raporcie: tamże, s. $81 \mathrm{i} \mathrm{nn.}$ 
umowy. Jeżeli w trakcie procesu ujawnią się okoliczności wskazujące, że umowa miała nielegalny cel, wówczas sąd uzna umowę za nielegalną, nawet jak istnienie tych okoliczności nie zostałoby potwierdzone przez strony ${ }^{176}$.

Centralnym założeniem i zarazem punktem wyjściowym dla postawienia zarzutu nielegalności, i wynikającej z tego sankcji, jest wspomniana zasada systemu prawa, że sądy nie powinny zajmować się sporami, gdzie strony nie przestrzegały prawa lub postępowały niemoralnie i niegodziwie.

Dalsze cechy tej instytucji są pochodną tej zasady podstawowej. Dotyczą one zarówno uzasadnienia surowej zasady podstawowej, jak i opracowania pewnych wyjątków ją łagodzących. Wszystko to sprawia, że skutki nielegalności są zróżnicowane, wiele kwestii jest bardzo niejasnych i budzi spory na tyle poważne, że postuluje się wspomniane formy ustawowego uregulowania albo całego obszaru tej wadliwości albo pewnych jej fragmentów.

Następstwa nielegalności determinowane są także tym, czy przyczyna nielegalności istniała w chwili zawarcia umowy, czy też naruszenia prawa są jedynie okolicznościami dalszymi, dotyczącymi samego sposobu wykonania umowy. Ewentualnie zarzut nielegalności może opiera się na dążeniu do celu zabronionego przez ustawę lub interes publiczny.

Zaistnienie przyczyny nielegalności w chwili dokonywania umowy powoduje, że tak samo jak w tradycji ius civile, co do zasady uznaje się nielegalną umowę za nieważną ab initio. Wówczas jest przez prawo traktowana, jakby nie została nigdy dokonana. Nie jest możliwe wywodzenie $z$ umowy jakichkolwiek roszczeń, łącznie $\mathrm{z}$ roszczeniem o odszkodowanie ${ }^{177}$, zgodnie $\mathrm{z}$ zasadą ex turpi causa non oritur actio ${ }^{178}$. Jej charakter jest bardzo surowy, jeśli pod uwagę zostaną wzięte dalsze następstwa, co tłumaczy się względami nie tylko sprawiedliwości, a racjami polityki, które nie pozostawiają miejsca na uznaniową ocenę sądu ${ }^{179}$.

Nieco odmiennie sprawa przedstawia się w przypadku odszkodowania. Jeżeli jedna ze stron wykonała umowę, wówczas zasadą jest brak możliwości żądania zwrotu spełnionego świadczenia; własność oraz pieniądze nie mogą zostać odzyskane (np. sprzedawca, który dostarczył towar nie ma roszczeń na wypadek braku zapłaty za towar; podobną pozycję prawną ma kupujący $)^{180}$. Działanie tej reguły prowadzi do zaskakujących efektów, np. jeżeli została zawarta umowa najmu w nielegalnym celu, trwa ona do końca umówionego okresu ${ }^{181}$.

176 G.C. Cheshire, CH Fifoot, M. Furmston [w: ] Law of Contract, s. 375.

177 R. Stone, The Modern Law..., s. 359.

178 The Law Commission, Illegal Transactions..., s. 7; G.C. Cheshire, C.H. Fifoot, M. Furmston [w: ] Law of Contract, s. 359-360.

179 J. Beatson, Anson's Law..., s. 382, za orzeczeniem Tinsley v. Milligan. [1994] 1 AC 340.

180 G.H. Treitel, The Law..., s. 377; G.C. Cheshire, CH Fifoot, M. Furmston [w: ] Law of Contract, s. 359; J. Beatson, Anson's Law..., s. 388.

181 G.C. Cheshire, CH Fifoot, M. Furmston [w: ] Law of Contract, s. 363. 
Wprowadza zasada ogólna de facto przepadek spełnionego świadczenia, porównywalny do polskiej regulacji, z tym że następuje na rzecz drugiej strony ${ }^{182}$. W systemach prawnych common law istnieje wzmiankowana we wcześniejszych uwagach możliwość nabycia tytułu prawnego na mocy nielegalnej umowy ${ }^{183}$.

Prawo Nowej Zelandii zastosowało inną regulację. Zgodnie z sekcją 73 Contract and Commercial Law Act 2017 (poprzednio art. 6 Illegal Contracts Act 1970), żadna osoba nie staje się uprawniona na mocy nielegalnej umowy, a w świetle art. 76, sąd może uchylić skutki nielegalności poprzez przywrócenie stanu poprzedniego, odszkodowanie, zmianę umowy, dokonanie jej konwalidacji w części lub całości albo tylko w odniesieniu do osiągnięcia określonego celu umowy. Sąd może także zastosować każdy inny środek ochrony prawnej, jaki uzna za właściwy w okolicznościach konkretnej sprawy. Te środki ochrony prawnej mogą być przyznane w każdym postępowaniu lub zastosowane dla osiągnięcia takiego celu. Ponadto sąd może przysądzić własność dla osiągnięcia skuteczności środków prawnych (por. sekcja 76 pkt 4 ww. ustawy z 2017).

Powyższa regulacja jest przykładem bardzo elastycznej normy wprowadzającej tzw. sankcję sędziowską w miejsce sankcji ex lege. Model władzy dyskrecjonalnej jest w zasadzie nieograniczony, ponieważ sąd ma szeroki wybór ingerencji w zakres określenia następstw danego naruszenia.

Oceniając podejście prawa Nowej Zelandii (jeszcze pod rządami Illegal Contracts Act 1970), w literaturze podkreślano, że legislacja ta przyjęła zasadę całkowitego wyczyszczenia skutków nielegalności. Sąd może usuwać skutki prawne zgodnie z oczekiwaniami wymiaru sprawiedliwości: uznaniowość opiera

182 Por. szerzej, na temat świadczenia niegodziwego w common law oraz w prawie rzymskim, m.in. P. Księżak, Świadczenie niegodziwe..., s. 7, s. 67-90.

183 The Law Commission, Illegal Transactions..., s. 38-39,109. Wyjątkiem jest: obrót rzeczami związanymi z czynami przestępczymi lub działalnością sprzeczną z dobrymi obyczajami, w celu obejścia przepisów, które wyraźnie wprowadzają sankcje braku skuteczności prawnej (tamże, s. 43). Podobne stanowisko obecne jest w piśmiennictwie kanadyjskim por. np. P.D. Maddaugh, J.D. McCamus, The Law..., s. 15-1 i nn. Należy wskazać, że może to być tendencja podlegająca korekcie, np. brak możliwości odzyskania własności został w orzeczeniu Al-Kishtaini v. Shanshal [2001] uznany za sprzeczny z Europejską Konwencją Praw Człowieka, przyjętą w prawie angielskim przez Human Rights Act 1998. Odmowę restytucji uznano za naruszenie prawa własności - jej bezpodstawne pozbawienie. Orzeczenie to uznaje się za początek tendencji, aby ograniczenie możliwości dochodzenia zwrotu świadczenia spełnionego w ramach wykonania nielegalnej umowy podyktowane było jedynie interesem publicznym. Nawet przy tej zasadzie uznaje, że może być uprawnione w konkretnych okolicznościach zastosowanie dalszych wyjątków - R. Stone, The Modern Law..., s. 362. W najnowszych opracowaniach została dostrzeżona w prawie angielskim konieczność zachowania zgodności przy stosowaniu doktryny illegality z prawem Unii Europejskiej oraz z postanowieniami Europejskiej Konwencji o Ochronie Praw Człowieka i Podstawowych Wolności por. szerzej, wraz z dalszym orzecznictwem, The Law Commission, The Illegality Defence..., s. $42-47$. 
się na niewielkiej liczbie wskazówek; przepis odwołuje się do tradycyjnych przesłanek rozstrzygania o zasadach przywrócenia stanu poprzedniego, m.in. wiedza strony na temat nielegalnego charakteru jej postępowania. Należy wziąć pod uwagę także zachowanie stron, cel naruszenia przepisów oraz kary związane z jej naruszeniem, a także każdą inną okoliczność, którą uważa za właściwą ${ }^{184}$.

Warto także zwrócić uwagę na bardzo szerokie pole, dzięki sędziowskiej władzy dyskrecjonalnej, do konwalidacji przez odrzucenie sankcji nieważności bezwzględnej. Rozwiązania systemowe idą dalej: co do zasady przyznaje się sędziemu kompetencje do ustalenia treści zobowiązań stron nielegalnej umowy. Jeżeli obie strony zawiniły w równym stopniu w wystąpieniu przyczyny nielegalności umowy (status stron jest in pari delicto), sytuacja procesowa pozwanego jest korzystniejsza niż powoda, zgodnie z zasadą in pari delicto, potior est conditio defendentis ${ }^{185}$. W takim przypadku pozwany może zatrzymać to, co uzyskał od powoda ${ }^{186}$. Ten ostatni przypadek można określić mianem prywatnoprawnego przepadku mienia na rzecz osoby odpowiedzialnej za nielegalność. Przyjmuje się jednak wyjątki od zasady braku zwrotu spełnionego świadczenia. Ogólnie zastrzega się przy tym, że nie jest możliwe dochodzenie odszkodowania w zakresie utraconych korzyści ${ }^{187}$.

Prawo do roszczeń restytucyjnych przyznaje się w następujących przypadkach:

a. jeżeli tylko jedna ze stron umowy odpowiada za przyczynę jej nielegalności, wówczas sąd dopuści możliwość odzyskania spełnionego świadczenia przez tzw. niewinną stronę. Powód musi w takiej sytuacji wykazać, że jest ofiarą podstępu, przymusu ze strony pozwanego, bądź że działał pod wpływem błędu co do faktu lub prawa ${ }^{188}$. Alternatywnie chroni się zaufanie do tzw. powierniczej pozycji pozwanego, którą pozwany następnie nadużył (np. jeżeli ubezpieczyciel zapewnia ubezpieczającego o ważności i zgodności z prawem umowy ubezpieczenia) ${ }^{189}$. W takich sytuacjach nielegalność umowy nie stanowi zarzutu, który może zostać podniesiony przeciwko roszczeniu restytucyjnemu ${ }^{190}$. Szczególnym

184 P. Birks, Recovering Value..., s. 155-156.

185 The Law Commission, Illegal Transactions..., s. 7, 86; G.C. Cheshire, C.H. Fifoot; M. Furmston [w: ] Law of Contract, s. 361.

186 Tamże, s. 362-363.

187 Ten środek ochrony prawnej ma na celu doprowadzenie do stanu sprzed dokonania transakcji - por. np. R. Halson, Contract..., s. 221-222.

$188 \mathrm{~W}$ prawie angielskim błąd co do prawa nie dawał roszczenia restytucyjnego aż do czasu orzeczenia Kleinwort Benson Ltd v. Lincoln City Council [1998] - The Law Commission, Illegal Transactions..., s. 31. Pomimo tego orzeczenia tylko błąd co do faktu uznaje się za wyjątek umożliwiający restytucję - por. np. P.D. Maddaugh, J.D. McCamus, The Law..., s. 15-17.

189 G.C. Cheshire, C.H. Fifoot, M. Furmston [w: ] Law of Contract, s. 366; P. Gillies, Concise Contract..., s. 170.

190 Por. szerzej The Law Commission, Illegal Transactions..., s. 28-34. 
przykładem zastosowania tego wyjątku są regulacje prawne, które mają na celu ochronę jednej ze stron umowy (np. najemców nieruchomości), wówczas czynsz zapłacony z tytułu umów zawartych z naruszeniem stosownych regulacji prawnych może zostać odzyskany przez najemcę ${ }^{191}$;

b. jeżeli powód zrezygnuje $z$ wykonania umowy, nie spełni świadczenia i „wyrazi żal” (repentance), albo jeżeli nie doszło jeszcze do wykonania umowy w znaczącej części ${ }^{192}$. Na mocy tej swoistej dla prawa prywatnego koncepcji tzw. czynnego żalu możliwe jest odzyskanie przez powoda spełnionego przez niego świadczenia. Warunkiem jest wycofanie się z umowy we właściwym czasie, zanim nielegalny cel umowy zostanie osiągnięty oraz powód musi autentycznie żałować przyczyny nielegalności w ocenie sądu. Zrezygnować powinien z własnej woli, nie zaś pod wpływem okoliczności, nad którymi nie miał kontroli, w szczególności ze względu na naruszenie umowy przez drugą stronę ${ }^{193}$. Cel umowy, jak się przyjmuje, nie musi być także zrealizowany w całości ${ }^{194}$. Generalną podstawą tego wyjątku jest brak wystąpienia poważnej przyczyny nielegalności, np. popełnienie przestępstwa ${ }^{195}$. W tym przypadku w nowszych wypowiedziach nauki wskazuje się na tendencję do wspierania doktryny czynnego żalu podejściem bardziej elastycznym, a mianowicie wyważeniem okoliczności relewantnych dla roszczenia $\mathrm{z}$ bezpodstawnego wzbogacenia (balancing of factors $)^{196}$;

c. jeżeli powód nie musi opierać roszczenia o zwrot na nielegalnej umowie, a jego roszczenie może być oparte na innej podstawie prawnej ${ }^{197}$;

d. jeżeli strony działały w błędzie odnośnie do faktu, który powoduje nielegalność umowy ${ }^{198}$.

191 G.C. Cheshire, C.H. Fifoot, M. Furmston [w: Law of Contract, s. 366; J. Beatson, Anson's Law..., s. 391-392.

192 R. Stone, The Modern Law..., s. 363.

193 G.C. Cheshire, C.H. Fifoot, M. Furmston [w:] Law of Contract, s. 369-370; J. Beatson, Anson's Law..., s. 334, por. szerzej wraz z wyczerpującym opracowaniem orzeczeń raport The Law Commission, Illegal Transactions..., s. 35-38. Zagadnienie to jest nazywane doktryną locus poenitentiae (wycofanie się z transakcji przed jej sfinalizowaniem, tzw. place/time of repentance: „wyrażenie skruchy”).

194 J. Beatson, Anson's Law..., s. 389.

195 Por. The Law Commission, Illegal Transactions..., s. 38; P. Gillies, Concise Contract..., s. 171.

196 Por. wraz z dalszym piśmiennictwem A.S. Burrows, A New Dawn for the Law of Illegality, „Oxford Legal Studies Research Paper” 2017, nr 42, s. 5-6, 14.

197 R. Halson, Contract..., s. 222, 226-228.

198 The British Columbia Law Institute, Report on Relief Under Legally Defective..., s. 14. 
Stan obustronnej nieegzekwowalności przyjmowany jest nawet w odniesieniu do umów, które naruszają zakaz ustawowy istniejący w chwili ich zawierania, jeżeli tylko jedna strona postępowała z naruszeniem prawa ${ }^{199}$.

Jak zostało wspomniane, następstwa nielegalności rozciągają się na umowy zawarte na podstawie nielegalnej umowy lub powiązane $\mathrm{z}$ nielegalną umową; umowy o ustanowienie dodatkowych zabezpieczeń, które stają się wówczas nieegzekwowalne (ciąg transakcji) ${ }^{200}$. Wyjątkiem jest nabycie prawa w dobrej wierze przez osobę trzecią na podstawie papieru wartościowego ${ }^{201}$.

Odmiennie sytuacja kształtuje się w razie naruszenia przepisów na etapie wykonywania umowy, która w chwili zawarcia nie jest wadliwa. Wówczas uznaje się, że „niewinna” strona może zawsze być uprawniona do dochodzenia roszczeń z umowy, może odzyskać spełnione świadczenia, a także dochodzić roszczeń z tytułu naruszenia umowy. Wszelkie prawa $z$ umowy oraz inne środki ochrony prawnej traci natomiast strona odpowiedzialna za przyczynę nielegalności ${ }^{202}$. Ochrona „strony niewinnej” ustaje jednak z chwilą uzyskania wiedzy o nielegalności umowy albo jeżeli umowa mogła być wykonana tylko z naruszeniem prawa ${ }^{203}$. Nielegalność umowy może uprawniać do roszczeń deliktowych, jednakże nie we wszystkich przypadkach, np. darowizna spełniona na rzecz organizacji w celu uzyskania szlachectwa, które nie mogłoby przez tę organizację być uzyskane dla darczyńcy (czyli darowizna spełniona w celu uzyskania efektu sprzecznego z prawem). Odszkodowanie za to oszustwo nie zostało przyznane, pomimo jego udowodnienia, ponieważ darczyńca miał świadomość moralnej niegodziwości takiej umowy ${ }^{204}$.

Zastrzeżenia formułowane pod adresem poprawności orzeczeń opierających się na klasycznym sankcjonowaniu nielegalności spowodowały wspomniane wszczęcie prac nad reformą m.in. w prawie angielskim oraz kanadyjskim $^{205}$. W kwestii podwalin reformy modelu tej sankcji decydujące było w prawie angielskim zastosowanie zasady testu „sumienia publicznego” (public conscience

199 The Law Commission, Illegal Transactions..., s. 20.

200 Tamże, s. 46-48.

201 J. Beatson, Anson's Law..., s. 343, 397-398. Autor stwierdza, co warto przywołać ponownie, zważywszy na konwencję terminologiczną, że możliwość ta wynika także z tej okoliczności, że wówczas nie dochodzi do nielegalnej transakcji, a jedynie do nieważnej (void).

202 Por. The Law Commission, Illegal Transactions..., s. 20; G.C. Cheshire, C.H. Fifoot, M. Furmston [w: ] Law of Contract, s. 337-338.

203 Tamże, s. 373.

204 The Law Commission, Illegal Transactions..., s. 45. Parkinson v. College of Ambulance Ltd and Harrison [1925]. Sąd odrzucił zarówno roszczenie odszkodowawcze ex delicto i ex contractu.

$205 \mathrm{~W}$ tym przypadku konieczne jest zastrzeżenie, że podstawowe tło prac związane jest z koniecznością uniformizacji prawa kanadyjskiego: common law z ius civile, które obowiązuje w prowincji Québec. 
test), pozwalającej na uniknięcie niektórych zbyt surowych skutków nielegalności umów. Między innymi było możliwe uznanie roszczeń o wykonanie umów, jeżeli nie byłoby to „afrontem” dla tzw. sumienia publicznego. W ramach tego testu sąd miał uwzględnić okoliczności towarzyszące danej sprawie oraz zważyć na konsekwencje odrzucenia nielegalności w opozycji do zastosowania tej sank$\mathrm{cji}^{206}$. Zasada testu sumienia publicznego została jednak odrzucona ze względu na jej nieuporządkowaną uznaniowość oraz jej mgliste przesłanki ${ }^{207}$.

W prawie angielskim głównym założeniem reformy było zaproponowanie szerokiej uznaniowości w orzekaniu o uznaniu umowy za nielegalną oraz o skutkach tej wadliwości, jednocześnie w modelu sankcji sędziowskiej uporządkowanej (structured discretion). Uzasadnieniem dla sankcji sędziowskiej przede wszystkim było odrzucenie stosowania sztywnych reguł prowadzących do nieproporcjonalnych reakcji na wadliwość, które skutkowały niesprawiedliwymi orzeczeniami, aż do rozstrzygnięć o charakterze quasi-karnym ${ }^{208}$.

Ponadto zaproponowano wykluczenie albo znaczące ograniczenie zasady obowiązującej do tej pory w prawie angielskim, w myśl której ten, kto zwraca się o orzekanie na podstawie słuszności (equity) sam powinien mieć czyste ręce ${ }^{209}$.

W początkowej wersji z 1999 r. założenia opierały się na uznaniowości w odmianie ograniczonej dyskrecjonalności (structured discretion), gdyż nie pozostawiono pełnej dowolności sędziemu, który musi każdorazowo uwzględnić konieczność ustalenia pewnych okoliczności, niezbędnych dla późniejszego orzeczenia o skutkach nielegalności. Sąd miał wedle pierwotnych założeń reformy oceniać:

- wagę nielegalności w tym sensie, aby ustalić, jak poważne są naruszenia (np. czy nielegalność będzie polegać na zleceniu morderstwa, czy też na nieprawidłowym parkowaniu),

- wiedzę i intencje powoda, ponieważ co do zasady strona, która nie odpowiada za nielegalność, może wywodzić z umowy roszczenia,

- czy odrzucenie możliwości przyznania środka ochrony prawnej (relief) będzie działało jako środek odstraszający (deterrent) innych uczestników obrotu prawnego od zawierania lub wykonywania nielegalnych umów oraz czy będzie to zgodne z celem zasady (lub przepisu ustawy), której naruszenie było przyczyną nielegalności umowy. W uzasadnieniu tej propozycji wskazano, że sądy nie powinny odmawiać prawnych lub słusznościowych środków ochrony prawnej, tylko dlatego, że związane

206 Por. tamże, s. 78 wraz z piśmiennictwem i orzeczeniami przyjmującymi dopuszczalność tej zasady.

207 Tamże, s. 78, 92. Zasada ta została odrzucona w sprawie Tinsley v. Milligan [1994].

208 Tamże, s. 91.

209 Tamże, s. 76. 
były $\mathrm{z}$ działaniem $\mathrm{w}$ celu sprzecznym $\mathrm{z}$ prawem; celowe jest m.in. uwzględnienie celu przepisu naruszonego, skutkującego nielegalnością umowy oraz by nie stworzyć precedensu dla innych ${ }^{210}$,

- czy odrzucenie możliwości przyznania rekompensaty (relief) jest proporcjonalne do stopnia naruszenia (nielegalności).

Sąd w myśl propozycji projektu reformy miał mieć prawo do odmowy zastosowania zarzutu nielegalności jako obrony przed roszczeniem o zwrot bezpodstawnego wzbogacenia. Mógł także odmówić ważności i zarządzić zwrotne przeniesienie danego prawa własności. Zaproponowano także ochronę rozporządzeń na rzecz osoby, która nabyła prawo od strony nielegalnej umowy bez wiedzy o przyczynie nielegalności ${ }^{211}$.

Warto zwrócić uwagę na dość znamienną ewolucję tej reformy. W 2009 r. w kolejnym raporcie konsultacyjnym przyjęto jednak, że model structured discretion nie będzie rozwiązaniem obecnych problemów z nieracjonalnością i brakiem proporcjonalności sankcji. Uznano, że wciąż orzekanie opierać się będzie na niejasnych regułach i wbrew intencjom reformy może to pogorszyć obecną sytuację.

Duże znaczenie dla takiej oceny ma fakt, że w czasie obowiązywania ustawy jeszcze z 1970 r. w Nowej Zelandii pojawiły się także istotne wątpliwości i spory na tle zakresu jej stosowania, m.in. nawet dotyczące wykładni ustawowej definicji nielegalnej umowy ${ }^{212}$. Pod adresem structured discretion zgłoszono także to zastrzeżenie, że wśród rozmaitych środków prawnych opisanych w The Illegal Contracts Act 1970, w sekcji 7 (3) nie zawarto dostatecznej informacji dla sądu, jak je zastosować oraz jaką regułę wyjściową zastosować do określenia sankcji dotyczącej nielegalnej (nieważnej) umowy. Odmiennie uczyniono to w modelu strukturalnej uznaniowości w The Israeli Contract (General Part) Law 1973; regułą wyjściową jest wprowadzenie obustronnej dostępności roszczeń restytucyjnych wg sekcji 31 ww. ustawy w zw. z sekcją $21^{213}$.

W Wielkiej Brytanii, rezygnując $z$ prac nad ustawą, zostawiono rozwój illegality orzecznictwu (case law). Wyjątek planowano uczynić w zakresie ustawy dotyczącej skutków nielegalności trustów lub w odniesieniu do czynów

210 Ta propozycja jest bardzo zbliżona do poglądów wyrażanych, np. w polskiej czy niemieckiej nauce, że działanie sankcji nieważności bezwzględnej nie powinno wykraczać dalej niż cel przepisu wprowadzającego sankcję nieważności bezwzględnej.

211 Tamże, s. 101. W raporcie pozostawiono do oceny problem ważności nabycia, jeżeli umowa, na mocy której osoba trzecia nabyła określoną rzecz lub prawo była sama w sobie nielegalna.

212 Por. The Law Commission, The Illegality Defence..., s. 53 oraz przytoczone tam orzecznictwo.

213 P. Birks, Recovering Value Transferred..., s. 156-157, 158. Autor także szerzej podejmuje krytykę uznaniowości w kontekście przepisów o konfiskacie mienia w przypadku przestępstw. 
niedozwolonych ${ }^{214}$. Ostatecznie nie spotkało się to z aprobatą rządu i zaprzestano dalszych prac w $2012 \mathrm{r}^{215}$.

W pewnym uproszczeniu główny problem, który skutkował rezygnacja z reformy, dotyczył poprawności zdefiniowania przesłanek orzekania o skutkach nielegalności i zakresu wytyczonych granic uznaniowości. Problemy na tym polu uznano za kolejny przyczynek do wzrostu niepewności i nieprzewidywalności rozstrzygnięćc ${ }^{216}$.

Interesujące jest, że w raporcie z 2009 r. dostrzeżono, że sam fakt zwrócenia uwagi sędziemu na konieczność badania, jak ocena sposobu wykonania umowy może wpłynąć na jej nielegalność, mógłby - wbrew intencjom reformy - spowodować rozszerzenie zakresu stosowania sankcji nielegalności w przypadku uznania w wyniku tej oceny, że świadczenia stron były prawnie wadliwe ${ }^{217}$. W raporcie tym jednocześnie podkreślono, że sądy powinny mieć na względzie rozważenie następujących okoliczności (przy spełnieniu ogólnych przesłanek uznania nielegalności wskazanych powyżej):

- czy przyznanie roszczenia (skargi) z umowy nie podważy celu naruszonej normy prawnej,

- powagę wykroczenia przeciwko przepisom,

- związek przyczynowy pomiędzy roszczeniem a nielegalnym zachowaniem,

- ocena zachowania stron umowy,

- proporcjonalność w odrzuceniu roszczenia z umowy ${ }^{218}$.

Należy zwrócić uwagę, że przesłanki te są w dużym stopniu porównywalne z sankcją sędziowską zaproponowaną w prawie modelowym PECL i DCFR.

Istotna rewizja poglądów angielskiej komisji kodyfikacyjnej koresponduje ponadto ze zmianą klasycznego modelu określania skutków nielegalności w kanadyjskim orzecznictwie (która wyraża się, podobnie jak w innych jurysdykcjach common law, przez naczelne zasady: odstraszania, potępienia i pieczy nad standardami porządku publicznego, nawet za cenę tolerowania niesprawiedliwości wskutek odmowy restytucji). Obecnie podkreśla się, że w ostatnich rozstrzygnięciach sądów szerzej dopuszczono możliwość przyznania ochrony w zakresie roszczeń kontraktowych stron oraz o przywrócenie stanu poprzedniego $^{219}$. W zakresie oceny sądu leży rozważenie m.in. takich okoliczności, jak: zawarcie umowy o celu nielegalnym lub w złych zamiarach, wzajemna pozycja

214 Por. szerzej The Law Commission, The Illegality Defence..., s. 8 i nn.

215 Por. raport Ministra Sprawiedliwości Wielkiej Brytanii, Report on the implementation of Law Commission proposals, marzec 2012, s. 14-15.

216 The Law Commission, The Illegality Defence..., s. 54.

217 Tamże, s. 51.

218 Por. szerzej tamże, s. 56-64.

219 Tamże, s. 26. 
negocjacyjna stron umowy, ich zachowanie podczas osiągania porozumienia, a także znaczenie bezpodstawnie uzyskanego dochodu przez dłużnika w razie zastosowania zasady braku interwencji ${ }^{220}$.

Ewolucja modelu sankcji sędziowskiej wydaje się wyjątkowo cennym materiałem porównawczym. Odmiany innego podejścia do sankcji sędziowskiej najczęściej sprowadzają się do jej bardzo elastycznego modelu.

W prawie kanadyjskim, $w$ trakcie prac nad unifikacją sankcji z tytułu nielegalności, w projekcie Uniform Illegal Contracts Act z 2008 r. również zaproponowano model szerokiej władzy dyskrecjonalnej sędziego w przyznaniu ochrony z nielegalnej umowy. Może to nastąpić poprzez (środki prawne mogą być łączone) $\mathrm{m}$.in. restytucję, odszkodowanie i rekompensatę zasadzoną od winnej strony, proporcjonalny rozdział strat (apportionment of a loss) 221 . W żadnym przypadku nie jest dopuszczalne wliczenie do wartości roszczeń utraconych korzyści. Możliwe są ponadto dalsze działania w celu zmiany wartości roszczeń.

Szczegółowo uregulowano przesłanki kognicji sądu w orzekaniu o skutkach nielegalności. Zgodnie z sekcją 6 ww. projektu, sąd do decyzji o uznaniu lub oddaleniu roszczeń powinien zważyć następujące okoliczności:

a. interes publiczny,

b. okoliczności zawarcia, obowiązywania lub wykonania nielegalnej umowy włącznie z zamiarami, wiedzą, postępowaniem oraz stosunkami stron,

c. czy strony nielegalnej umowy, w czasie najistotniejszym ze względu na przyczynę nielegalności, działały pod wpływem błędu co do faktu lub prawa,

d. zakres, w jakim nielegalna umowa została wykonana,

e. czy umowa była nielegalna od chwili jej zawarcia, czy ze względu na okoliczności związane z wykonaniem umowy,

f. czy wady powstały z powodu ustawy, czy ustawa była w znacznym stopniu zgodna $z$ umową,

g. konsekwencje odrzucenia roszczeń strony,

h. inne czynniki, jakie sąd uzna za doniosłe ${ }^{222}$.

Zakres kognicji sądu ma realizować przede wszystkim zasadę reakcji proporcjonalnej na dane naruszenie. Jest to emanacja założenia obu systemów prawnych, że cel sankcji nie powinien być następstwami sankcji przekroczony. Powstaje pytanie, czy w zmianie sankcji na bardziej elastyczną nie ma ryzyka powielenia dotychczasowych problemów ze względu na zakres autonomii i spory

220 Tamże, s. 25 .

221 Por. szerzej tamże, s. 39-41. W przypadku rozdzielenia strat przyjęta jest ww. propozycja, jak się wydaje w celu przesądzenia, że nie jest możliwe podnoszenie zarzutów przyczynienia się poszkodowanej strony do nielegalności (tj. odrzucenie contributory negligence).

222 Por. tamże, s. 42-43. 
potencjał kreowania rozbieżnych rozstrzygnięć w tak ramowo zakreślonych regułach orzekania.

\section{§ 6. Stanowisko prawa amerykańskiego na tle systemów prawnych tradycji common law}

\subsection{Uwagi ogólne o typologii sankcji wadliwości}

W prawie amerykańskim również wyróżnia się trzy podstawowe postaci wadliwości umów: wzruszalność (voidable), nieważność bezwzględną (void) ${ }^{223}$ oraz nieegzekwowalność umowy (unenforceable). Nielegalność sprzężona jest z sankcją nieegzekwowalności umowy. Zetknąć się można z konwencją terminologiczną: nieważny z powodu nielegalności. Jednocześnie w poszczególnych stanach można doszukać się podejścia odmiennego od np. prawa Wielkiej Brytanii, Australii lub Nowej Zelandii, a mianowicie legislatorzy stanowi posługują się także odwołaniem do podziału na umowy bezprawne (unlawful) i wzruszalne (voidable). Ten pierwszy rodzaj umów objęty jest sankcją nieważności void ab initio. Jest to wyraźna obecność wpływów prawa kontynentalnego. W ramach przykładu można wskazać na prawo Dakoty Północnejej ${ }^{24}$ lub Kodeks cywilny stanu Kalifornia ${ }^{225}$.

Stanowisko prawa amerykańskiego w zakresie systematyki i następstw ww. sankcji wadliwości jest kompleksowo uregulowane, łącznie $\mathrm{z}$ definicjami danych typów wadliwych umów, w zbiorze: The Restatement (Second) of Contracts

223 Podobnie jak w innych krajach common law sankcja ta wynika także z naruszenia przepisów prawa stanowionego. W prawie amerykańskim przyjęcie tej sankcji wymaga łącznego uwzględnienia kilku przepisów prawnych (reguł prawa). W odniesieniu do nieważności ab initio - w przypadku zatajenia przez dłużnika przed poręczycielem informacji świadczących o ryzyku poręczanej transakcji - zastosowanie sankcji nieważności bezwzględnej wynika z § 164 The Restatement (Second) of Contracts, § 119 The Restatement (Third) of Security z 1941 r., The Restatement (Third) of Suretyship and Guaranty - tak, zwracając jednocześnie trafnie uwagę na rzadkość takiego oszustwa, E.G. Gallagher, The Law of Suretyship, Chicago 2000, s. 144.

224 Por. rozdział prawa umów i innych zobowiązań - Contracts and Obligations (9-08 Unlawful and Voidable Contracts), http://www.nd.gov. Kodeks tego stanu dość wyraźnie nawiązuje do pewnych rozwiązań romańskiego kręgu ius civile, np. wzorowany na Kodeksie Napoleona art. 9-01-02 [Requisites of contract] It is essential to the existence of a contract that there should be: 1. Parties capable of contracting; 2. The consent of the parties; 3. A lawful object; and 4. Sufficient cause or consideration.

225 Por. Kodeks cywilny Stanu Kalifornia - California Civil Code, sekcja: 1667-1670.6 (Tytuł 4: Unlawful Contracts). 
$\mathrm{z}$ roku $1981^{226}$. Sankcja unenforceable ma podstawowe zastosowanie w The Restatement (Second) of Contracts (w szczególności § 178, 184, 197, 198). Ze względu na zastosowanie uznaniowości w kreowaniu sankcji za naruszenie ustawy lub pozaustawowych (moralności lub porządku publicznego) celowe jest zapoznanie się z podejściem prawa amerykańskiego.

Warto odnotować w uzupełnieniu poprzednich rozważań, że w przypadku nieważności umów określenie „nieistniejąca umowa” stosuje się jako synonim nieważności ${ }^{227}$. W doktrynie francuskiej amerykańskie rozumienie terminu void uznaje się wprost za porównywalne do kategorii „nieistniejącej umowy”228.

Można spotkać się z orzeczeniami sądów amerykańskich, gdzie odróżnia się „nieistniejące umowy” od „umów nieważnych”, przypisując temu istotne konsekwencje.

Sytuacja taka została szczegółowo omówiona np. w orzeczeniu sądu apelacyjnego stanu Oregon z 2008 r. w sprawie Dess Properties, LLC v. Sheridan Truck \& Heavy Equipment, LLC, gdzie powództwo, m.in. o zasądzenie honorarium adwokackiego i innych kosztów, uregulowane umową sprzedaży; przysługujące $\mathrm{w}$ wyniku ewentualnych sporów $\mathrm{z}$ umowy sprzedaży, zostało oddalone. Zgodnie $z$ prawem stanu Oregon, możliwe jest przyznanie stronie wygranej zwrotu kosztów zastępstwa prawnego wyjątkowo w sytuacji sankcji nieważności bezwzględnej lub sankcji nieegzekwowalności ${ }^{229}$. Prawo takie nie powstałoby w razie ustalenia „nieistnienia” umowy. Sąd za taki przypadek uznał sytuacje, gdy nie doszło do zawarcia umowy, a jedynie strony uzgodniły sam jej projekt $\mathrm{t}^{230}$. Podkreślono

226 The Restatement (Second) of Contracts (1981). Na temat projektu por. the American Law Institute - www.ali.org.

227 Tak np. w orzeczeniu federalnego sądu apelacyjnego z 1.10.2001 r. Beverly Burden, et al. v. Check into Cash of Kentucky, Llc, et al. (United States Court Of Appeals for The Sixth Circuit). Takie podejście zostało ocenione krytycznie - choć raczej na tle pewnych implikacji tego orzeczenia, m.in. odrzucenia możliwości sankcji nieważności ograniczonej do części umowy, w sprawie Match-E-Be-Nash-She-Wish Band of Pottawatomi Indians v. Kean-Argovitz Resorts Llc (United States Court of Appeals, Sixth Circuit z 8.6.2004 r.). Podobnie o nieistnieniu umowy wypowiada się orzecznictwo na tle umów naruszających zasady wolnej konkurencji - por. szerzej np. B.M Malsberger, Covenants Not to Compete. A State-By-State Survey, wyd. 5, vol. 1, Arlington 2006, s. 16, 34. Na zamieszanie terminologiczne pod tym względem w prawie USA zwraca się także uwagę w nauce europejskiej - J.B. Racine, L. Sautonie-Laguionie, A. Tenenbaum, G. Wicker [w: ] European Contract Law, Materials for a Common Frame of Reference: Terminology, Guiding Principles, Model Rules, red. B. Fauvarque-Cosson, D. Mazeaud, München 2008, s. 356-357.

228 Tamże, s. 356.

229 Prawo Stanu Oregon zgodnie z Oregon Rules of Civil Procedure 20.083 ORS (por. komentarz na https://www.oregonlaws.org/ors/) przyznaje wyjątkowo roszczenie wygranej stronie procesu o zwrot kosztów od strony przegranej (jest to wyjątek od tzw. American Rule w zakresie kosztów zastępstwa prawnego).

230 Podobnie orzeczono w sprawie Golden Pisces, Inc. v. Fred Wahl Marine Construction, Inc, 2007 (federalny sąd apelacyjny, 9 Okręg, sprawa Nr 05-3547), opierając się, poprzez 
w orzeczeniu, że termin „nieważna umowa” ma znaczenie ustawowe i nie obejmuje nonexistent contracts ${ }^{231}$.

$\mathrm{W}$ ww. orzeczeniu ten typ wadliwości związany był z rażącym naruszeniem procesu zawierania umowy. Był to bardziej przypadek tzw. niedojścia umowy do skutku (w prawie polskim art. $76 \mathrm{KC}$ ). Taki wniosek można zilustrować odwołaniem się do unormowań § 163 lub § 174 The Restatement (Second) of Contracts $^{232}$, gdzie punktem wspólnym wyodrębnienia tzw. nieistniejących umów jest wystąpienie wadliwości skutkującej brakiem uformowania umowy (np. przymus fizyczny).

Problem wyodrębnienia sankcji „nieistniejących umów” rzutuje także na możliwość żądania postępowania arbitrażowego, jeżeli zarzuca się nieważność klauzuli arbitrażowej. Reguła podstawowa w ogólnym ujęciu stanowi, że gdy istotą procesu jest zarzut przeciwko ważności samej klauzuli arbitrażowej, wówczas właściwe są sądy powszechne ${ }^{233}$. Zagadnienie to rozstrzygane jest zgodnie z dorobkiem doktryny separability ${ }^{234}$, gdzie zakłada się fikcję prawną zawarcia dwóch odrębnych umów: umowy o sąd arbitrażowy (składającej się wyłącznie z samej klauzuli) oraz umowy podstawowejej ${ }^{235}$. Jeżeli istotą sprawy jest zarzut wadliwego zawarcia umowy podstawowej (zawierającej klauzulę arbitrażową), np. pod wpływem wady

zastosowanie $\$ 163$ Restatement (Second) of Contracts, na uznaniu nieważności umowy, a tym samym, że w ogóle nie była to umowa. Powoduje to, że nie jest możliwe uznanie częściowej ważności umowy (w zakresie umówionych kosztów adwokackich w takiej umowie).

$231 \mathrm{~W}$ uzasadnieniu oparto się na cytowanym komentarzu do § 7 The Restatement (Second) of Contracts oraz wypowiedzi A. Corbina. Sąd ten jednocześnie krytycznie ocenił definicję nieważnej umowy, o której mowa w Black's Law Dictionary, wedle której określenie „nieważna umowa” jest synonimem pojęcia „nieistniejącej umowy”. W uzasadnieniu powołano dalsze orzecznictwo, gdzie także oddziela się nieważność od nieistnienia umowy.

232 Por. § 163 The Restatement (Second) of Contracts oraz § 174 The Restatement (Second) of Contracts.

233 Por. wraz z przywołanym tam dalszym orzecznictwem, np. Beverly Burden, et al. v. Check into Cash of Kentucky, LLC, et al z 2001 r. (United States Court Of Appeals for the Sixth Circuit z 2001 r.). Sąd ten przywołał orzeczenia, gdzie uznano, że reguła Prima Paint ma zastosowanie do wzruszalnych (voidable), a nie do nieważnych umów (void), tj. Sandvik $A B$ v. Advent Int'l Corp oraz Three Valleys Municipal Water District v. E.F. Hutton \& Co. - blizej na ten temat P.J. Martinez-Fraga, The American Influence on International Commercial Arbitration doctrinal developments and discovery methods, Cambridge University Press 2009, s. 130, 131-150.

234 Por. np. S.J. Ware, Arbitration Law's Separability Doctrine After Buckeye Check Cashing, Inc. v. Cardegna, „Nevada Law Journal” 2007, vol. 8, nr 107, s. 110, N. Andrews, Arbitration and Contract Law..., s. 37. Autor ten zwraca uwagę, że w przypadkach nielegalności albo unieważnienia umowy, ważność klauzuli arbitrażowej w case law traktowana jest oddzielnie od oceny ważności umowy, jak w sprawie Harbour Assurance v. Kansa General International (1993), $\mathrm{z}$ wyjątkiem oszustwa lub działania bez umocowania przez pełnomocnika. W tych przypadkach wady te powodują stan nieważności klauzuli arbitrażowej - tak np. orzeczono w uzasadnieniu do Fiona Trust and Holding Corporation v. Privalov (2007) - por. tamże, s. 39-40.

235 S.J. Ware, Arbitration Law's Separability..., s. 109-110. 
oświadczenia woli, wówczas właściwy jest arbitraż, ponieważ nie jest kwestionowana wyłącznie sama klauzula (de iure umowa) o arbitraż $\dot{z}^{236}$.

Istnieje bogate orzecznictwo dotyczące tego zagadnienia. W Sądzie Najwyższym USA ${ }^{237}$ przeważa stanowisko, że możliwość żądania arbitrażu z „nieważnych umów" uzależniona jest od okoliczności, czy zarzuca się wadliwość samego porozumienia o arbitrażu, czy też nieważność całej umowy, zawierającej klauzulę o arbitrażu $u^{238}$.

Szczególnie w orzeczeniu Sądu Najwyższego USA Buckeye Check Cashing, Inc. v. Cardegna z 2006 r. mniejszą wagę przyznano rozróżnieniu na nieważność i wzruszalność, a podkreślono konieczność rozstrzygania kwestii ważności samej umowy podstawowej, wprowadzającej właściwość sądu arbitrażowego do rozpoznania sporów o ważność klauzuli arbitrażowej239. W uzasadnieniu (przypis nr 1) pojawiło się również wysoce kontrowersyjne stwierdzenie, że zagadnienie ważności umowy należy odróżnić od tego problemu, czy w ogóle jakiekolwiek porozumienie zostało zawarte, np. czy w ogóle nastąpiło podpisanie umowy, umocowanie do działania w cudzym imieniu, czy wreszcie zdolność psychiczna do złożenia oświadczenia woli ${ }^{240}$.

Stanowisko Sądu Najwyższego USA zostało poddane ostrej krytyce w piśmiennictwie ${ }^{241}$. Zważywszy na istotę wady trafnie podkreślono, że w sytuacji szczególnie poważnych przypadków wadliwości (np. sfałszowanie podpisu strony umowy, działanie bez umocowania w cudzym imieniu, brak zdolności do czynności prawnych, zawarcie umowy z osobą psychicznie chorą lub małoletnim), jakkolwiek sformułowany jest zarzut, to w istocie per se obejmuje zarzut braku samego porozumienia o arbitrażu (klauzuli umownej) ${ }^{242}$.

W orzeczeniu Beverly Burden, et al. v. Check into Cash of Kentucky, Llc, et al. dodatkowo wskazano, że istotne jest także zbadanie istnienia podstępu (oszustwa) co do faktów (fraud in the factum) i co do motywów (fraud in the inducement). Sąd podkreślił, że w komentarzu do The Restatement (Second) of Contracts w $\$ 163$ (1979) podstęp co do faktów lub co do wykonania (execution) powoduje nieważność umowy (contract void), natomiast podstęp co do motywów nakazuje przyjęcie wzruszalności umowy. Udowodnienie przyczyn

236 Por. szerzej tamże, s. 111.

237 Prima Paint Corp. v. Flood \& Conklin Mfg. Co, z 1967, drugim z kluczowych rozstrzygnięć w tym zakresie jest orzeczenie SN USA w sprawie Buckeye Check Cashing, Inc. v. Cardegna z 2006 r.

238 Por. szerzej, wraz z orzecznictwem i doktryną na ten temat, A.S. Rau, Separability in the United States Supreme Court, „U of Texas Law, Public Law Research Paper” 2006, nr 102, s. 17, 31 oraz N. Andrews, Arbitration and Contract..., s. 37.

239 Por. szerzej S.J. Ware, Arbitration Law's Separability..., s. 111.

240 Por. szerzej tamże, s. 115-117.

241 Por. w szczególności A.S. Rau, Separability in the United States..., s. 14 i nn.

242 Tamże, s. 14-15. 
takiej wadliwości powoduje, że roszczenia z umowy podlegają kognicji sądów powszechnych. W prawie angielskim powyższy problem rozwiązano ustawą. Arbitration Act 1996 w sekcji 7 wprowadza zasadę oddzielenia ważności umowy od ważności zapisu na sąd polubowny, ale przyznaje jednocześnie możliwość odmiennego umówienia się przez strony ${ }^{243}$.

Pomijając problem rozbieżnego definiowania nieważnej bezwzględnie umowy (void), w tym traktowania jej jako synonimu „nieistniejącej umowy”, w prawie amerykańskim można spotkać się dość często z konwencją wspólnego łączenia terminów „unenforceable and void”244.

Wśród podstaw zastosowania sankcji nieważności bezwzględnej wyróżnia się, obok sprzeczności z ustawą, m.in. brak przyczyny w zobowiązaniu (consideration). Termin ten jest ponadto stosowany często przy okazji naruszeń sankcjonowanych nieegzekwowalnością umowy, stąd też można zaobserwować wiele niekonsekwencji terminologicznych ${ }^{245}$.

W odniesieniu do amerykańskiego rozumienia cech sankcji wzruszalności (nieważności względnej) zauważa się w nauce europejskiej, że w odróżnieniu od stanowiska prawa niemieckiego i francuskiego (gdzie umowę podlegającą tej sankcji uznaje się za ważną z potencjalną możliwością unieważnienia), wzruszalną umowę postrzega się jako umowę, która równie łatwo może stać się ważna, jak i nieważna. W ten sposób umowy te zbliżone są do przypadków nazywanych w tradycji ius civile czynnościami prawnymi o zawieszonej ważności ${ }^{246}$. W przypadku sankcji wzruszalności doktryna angielska podkreśla, że umowa ta do czasu unieważnienia wywiera w pełni skutki prawne oraz osoba trzecia może nabyć w sposób ważny (skutecznie) własność ${ }^{247}$.

243 Por. Arbitration Act 1996, Section 7 (Separability of arbitration agreement).

244 Tak w orzecznictwie sądów stanowych na tle umów naruszających zasady wolnej konkurencji - por. szerzej np. B.M Malsberger, Covenants..., s. 16, 34. Na zamieszanie terminologiczne zwracają uwagę J.B. Racine, L. Sautonie-Laguionie, A. Tenenbaum, G. Wicker, European Contract Law, Materials..., s. 356-357.

245 Należy podkreślić, że nie oznacza to, że każdorazowo umowy naruszające te przepisy będą całkowicie pozbawione skutków prawnych - należy odwołać się do wykładni danego przepisu, a czasem jej rezultat będzie uprawniać do przyjęcia, że dane porozumienie ma pewne skutki prawne - por. szerzej A.L. Corbin, Corbin on contracts..., s. 11-12.

246 W. van Gerven, The Concept of Provisional..., s. 517, na podstawie cytatu z komentarza do The Restatement of the Law of Contracts (1932) autorstwa A.L. Corbin, Corbin on contracts. A Comprehensive Treatise on the Working Rules of Contract Law, St. Paul 1964.

247 Tak np. J. Beatson, Anson's Law..., s. 20. 


\subsection{Cechy formalne sankcji nieegzekwowalności (unenforceability) w prawie amerykańskim}

Z punktu widzenia prawa kontynentalnego podkreśla się, że prawo amerykańskie, podobnie jak angielskie, nie pozwala na precyzyjne oddzielenie sankcji nieważności bezwzględnej od wzruszalności. Prawo amerykańskie koncentruje się na proceduralnych skutkach danej wadliwości. Zwraca się uwagę na trudności w wytyczeniu czytelnej systematyki wadliwości ${ }^{248}$.

Systematyka wadliwości odwołuje się do zasady egzekwowalności umowy. Egzekwowalność (wykonalność), enforceability, uznaje się za centralną ideę amerykańskiego prawa. Umowa spełniająca warunki ważności jest „egzekwowalna”, jeśli prawo przewiduje roszczenie, na podstawie którego można żądać i otrzymać jej wykonanie. Widoczne jest, że termin ten odwołuje się do wykonawczego aspektu zobowiązań ${ }^{249}$.

Mając na względzie zakres pojęciowy terminu „nieegzekwowalny”, podobnie jak przy nieważności, zwraca się uwagę na wewnętrzną sprzeczność istnienia takiej wadliwej czynności prawnej ${ }^{250}$. Jest to kolejny aspekt dwupłaszczyznowego zakresu znaczeniowego terminu „nieważność”.

Poszczególne przypadki umów nieegzekwowalnych określone są w The Restatement (Second) of Contracts. Podobnie jak w innych systemach common law, w przypadku ustawowych ograniczeń swobody umów, prymat zastosowania mają skutki naruszenia wprost wskazane w danym przepisie. Jeżeli sankcja za niezgodność $z$ daną ustawą nie jest przewidziana, sąd musi rozważyć uzasadnienie naruszonego przepisu (policy) wynikające z ustawy, by podjąć decyzję w sprawie wykonalności praw z takiej umowy ${ }^{251}$. Przy tej okazji zasadnicze zastosowanie znajdą raczej zasady porządku publicznego aniżeli cel danej ustawy ${ }^{252}$.

Jak zostało wspomniane powyżej, najważniejszą podstawą do zastosowania ww. sankcji jest naruszenie porząadku publicznego. Wśród zasad porządku publicznego wyodrębnia się kilka głównych kategorii związanych z przedmiotem ochrony:

1. zasady dotyczące moralności,

2. zasady dotyczące ochrony wolności ekonomicznych, np. umowy o zakazie działalności konkurencyjnej, np. §§ 187 i 188 The Restatement (Second) of Contracts,

248 J.B. Racine, L. Sautonie-Laguionie, A. Tenenbaum, G. Wicker, European Contract Law, Materials..., s. 356

249 Tamże, s. 256.

250 Tak szerzej A.L. Corbin, Corbin on contracts..., s. 13.

251 The Law Commission, The Illegality Defence..., s. 40.

252 Tamże, s. 40. 
3. zasady dotyczące ochrony uczciwego sprawowania administracji oraz integralności wymiaru sprawiedliwości,

4. ochrona stosunków prawnych o charakterze fiducjarnym, np. umowy o określone wykonywanie prawa głosu w zarządzanych spółkach, o określony sposób zamian władz spółki, co narusza w szczególności zasadę najlepszego osądu ${ }^{253}$

5. naruszenie innych prawnie chronionych interesów (np. oświadczenie woli, które w sposób deliktowy zakłóca możliwość wykonania umowy z osobą trzecią lub w sposób deliktowy zachęca do złamania umowy, $\S 194$ The Restatement (Second) of Contracts.

W ramach kategorii umów naruszających zasady konkurencji, obok działalności handlowej kwalifikuje się także umowę o pracę. Ponadto przyjmuje się nielegalność klauzul wyłączających odpowiedzialność deliktową (exculpatory clauses $)^{254}$, klauzul wyłączających odpowiedzialność za wprowadzenie w błąd (misrepresentation) ${ }^{255}$, umowy zachęcające do wyrządzenia czynu niedozwolonego ${ }^{256}$ oraz umowy wyzyskujące drugą stronę (unconscionable contracts) ${ }^{257}$. Przyjmuje się, podobnie jak w prawie angielskim, interesujące w swym ratio legis założenie, że umowa naruszająca np. zasady konkurencji jest prima facie nieegzekwowalna; może uzyskać skuteczność prawną, jeżeli przemawiają za tym rozsądnie oceniane interesy stron umowy oraz interesy ogólne społeczeństwa ${ }^{258}$.

Wypada również wspomnieć o § 181 The Restatement (Second) of Contracts, gdzie „nieegzekwowalnością” sankcjonowane jest naruszenie przepisów wymagających uzyskania licencji, rejestracji lub podobnych wymogów. Wówczas oświadczenie woli jest nieegzekwowalne, jeżeli wymogi mają cel regulacyjny oraz interes w nadaniu skuteczności oświadczenia woli jest w sposób oczywisty przeważony przez zasady porządku publicznego, stojące za wprowadzeniem naruszonych wymogów ${ }^{259}$.

253 Por. J.P. Kostritsky, Illegal Contracts and Efficient Deterrence..., s. 117 wraz z przywołaną tam dalszą literaturą.

254 Por. § 195 The Restatement (Second) Of Contracts.

255 Por. $\$ 196$ The Restatement (Second) Of Contracts.

$256 \S 192$ The Restatement (Second) Of Contracts: A promise to commit a tort or to induce the commission of a tort is unenforceable one a grounds of public policy.

257 Por. R.A. Mann, B.S. Roberts, Smith and Roberson's Business..., s. 228-229. Nadużycie związane może być zarówno z okolicznościami dotyczącymi samego procesu zawarcia umowy (np. ukrywanie istotnych postanowień umowy w ramach tzw. małego druku - fine print), jak i odnoszącymi się do treści umowy, które to może polegać m.in. na „niebotycznej cenie”, wyłączeniu lub znacznym ograniczeniu odpowiedzialności kontraktowej - por. również sekcja 2-302 The Uniform Commercial Code oraz § 208 The Restatement (Second) Of Contracts.

$258 \mathrm{Na}$ podstawie orzeczenia w sprawie Harlequin Enterprises Ltd. v. Warner. Books (S.D.N.Y.1986), F.S. Newman [w: Commercial Contracts. Strategies for Drafting and Negotiating M. Moskin (red.), [b.d.] 2001, s. 8-41.

259 Por. $§ 181$ [Effect of Failure to Comply with Licensing or Similar Requirement]. 
The Restatement (Second) of Contracts, podobnie jak np. w prawie Nowej Zelandii, przyznaje wysoki poziom uznaniowości w ocenie skutków nielegalności umowy ${ }^{260}$. Zgodnie z $\$ 178$ The Restatement (Second) of Contracts ${ }^{261}$, umowa lub jej część jest nieegzekwowalna z powodu naruszenia porządku publicznego, jeżeli przepis wprost tak stanowi lub interes w uznaniu jej wykonalności prawnej jest w sposób wyraźny przeważony, w świetle okoliczności sprawy, zasadami porządku publicznego, które przemawiają przeciwko wykonalności prawnej takiej części umowy. Natomiast przy ocenie, czy zachodzi interes za nadaniem wykonalności prawnej części umowy uwzględnia się:

1. usprawiedliwione oczekiwania stron,

2. każdą stratę, która powstałaby w razie odmowy nadania wykonalności prawnej,

3. każdy rodzaj interesu publicznego, jaki przemawiałby za wykonalnością prawną danego postanowienia umowy.

Wobec ogólnego charakteru zasad porządku publicznego (public policy), jakie powinny przemawiać przeciwko nadaniu wykonalności prawnej umowie, ich konkretyzację dokonuje się na podstawie poniższych okoliczności:

1. istotność zasady porządku publicznego będącej uzasadnieniem przepisu lub orzeczenia sądu,

2. prawdopodobieństwo, czy odmowa nadania wykonalności prawnej umowie będzie promowała zasadę porządku publicznego, czy raczej wykroczy poza cel i uzasadnienie tej zasady,

3. powagę niewłaściwego postępowania stron oraz stopień jego umyślności,

4. bezpośredniość związków pomiędzy niewłaściwym zachowaniem stron a postanowieniem umowy ${ }^{262}$.

W przypadku nielegalności wywołanej nieprawidłowym wykonaniem umowy, wadliwości badanej, jeżeli treść lub cel umowy jest formalnie niewadliwa, postuluje się, aby nie każde niedozwolone zachowanie umożliwiało drugiej stronie zwolnienie się z odpowiedzialności za wykonaną pracę lub dostarczone towary. W szczególności nielegalność na skutek sposobu wykonania zachodzić będzie, jeżeli nielegalność jest centralną i dominującą częścią umowy, tj. dotyczy świadczenia powoda w wykonaniu umowy ${ }^{263}$.

260 The Law Commission, The Illegality Defence..., s. 40.

261 Szczegółowo analizę zarzutu naruszenia public policy w ramach zarzutów nielegalności umowy przeprowadził m.in. D.A. Friedman, Bringing Order to Contracts Against Public Policy, 39 Florida State University Law Review 2012, s. 575 i n. Autor za pomocą prawniczej bazy danych dokonał sprawdzenia statystycznie ile zarzutów niezgodności z porządkiem publicznym było podniesione przed sądami federalnymi i stanowymi od 1.07 do 31.12.2009 r.; wg autora było to 108 spraw na 1089 spraw - por. szerzej tamże, s. 580-582.

262 Por. § 178 [When A Term Is Unenforceable On Grounds Of Public Policy].

263 Tak np. F.S. Newman [w:] Commercial Contracts. Strategies..., s. 8-43. 
W doktrynie podkreśla się, że § 178 The Restatement (Second) of Contracts realizuje zasadę „żadnego skutku prawnego” (no effect). Model sankcji nie odwołuje się do pojęcia nieważności (void). Przyjęta terminologia wyjaśnia konsekwencje nielegalności odnośnie do braku zarówno wykonalności umowy, jak i ewentualnych roszczeń restytucyjnych ${ }^{264}$. Podkreśla się, że koncepcja nielegalności jest sądową ingerencją w prywatne porozumienie poprzez odmowę nadania mu skutków prawnych, stąd jest jednym z przykładów odstępstwa od zasady braku interwencji w autonomię woli stron (private ordering). Taka ingerencja musi być przede wszystkim uzasadniona potrzebą przestrzegania zasady porządku publicznego ${ }^{265}$.

Fundamentalne następstwo braku roszczeń z umowy nielegalnej wyraża się w $\$ 197$ The Restatement (Second) of Contracts, który stanowi, że strona nie ma roszczenia o zwrot świadczenia spełnionego z umowy, chyba że odmowa roszczenia o zwrot powodowałaby nieproporcjonalną stratę 266 .

Ochronę strony, która nie zawiniła w tym samym stopniu jak druga strona w wystąpieniu nielegalności umowy (albo gdy brak świadomości strony o sprzeczności z porządkiem publicznym jest usprawiedliwiony w danych okolicznościach sprawy), statuuje § 198 The Restatement (Second) of Contracts, wskazując, że osoba taka ma prawo do roszczenia o zwrot spełnionego świadczenia ${ }^{267}$.

Natomiast § 199 The Restatement (Second) of Contracts przyznaje zgodnie $\mathrm{z}$ zasadą locus poenitentiae roszczenie tej stronie umowy, która wycofała się z umowy we właściwym czasie oraz nie była zaangażowana w przyczyny nielegalności, pod dalszym warunkiem, że niewłaściwy cel transakcji nie został osiągnięty lub przyznanie roszczenia o zwrot zakończy sytuację, która jest sprzeczna $\mathrm{z}$ porządkiem publicznym ${ }^{268}$.

Podobnie jak w innych systemach prawnych common law przyjmuje się dopuszczalność częściowej nielegalności, jeżeli jest możliwe oddzielenie części nielegalnej (np. umowa zawierająca niedozwoloną klauzulę o zakazie konkurencji ${ }^{269}$.

Obok powyższych zasad ogólnych warto zwrócić uwagę na regulację § 356 The Restatement (Second) of Contracts, gdzie została określona sankcja nieegzekwowalności w razie naruszenia przepisów dotyczących zasad określania

264 Por. J.P. Kostritsky, Illegal Contracts and Efficient Deterrence..., s. 117.

265 Por. tamże, s. 119 i nn.

266 Por. § 197 [Restitution Generally Unavailable].

267 Por. $§ 198$ [Restitution in Favor of Party Who Is Excusably Ignorant or Is Not Equally in the Wrong].

268 Por. § 199 [Restitution Where Party Withdraws or Situation Is Contrary to Public Interest].

269 Por. R.A. Mann, B.S. Roberts, Smith and Roberson's Business..., s. 229. Do ww. przykładów nielegalnych umów odwołują się przepisy $\$$ 186,187,188,192-196 The Restatement (Second) of Contracts. 
wysokości odszkodowania umownego z tytułu naruszenia umowy, np. w razie opóźnienia (zwłoki). Wysokość ta nie może być nierozsądnie wysoka względem strat, jakie są poniesione lub spodziewane jeszcze do wystąpienia; i nie może stanowić sankcji karnej dla strony ${ }^{270}$.

Oceniając powyższe regulacje, szczególnie § 178 The Restatement (Second) of Contracts, trudno oprzeć się wrażeniu, że w zasadzie stanowisko większości krajowych systemów common law jest zbliżone w wysiłkach mających na celu zapewnienie proporcjonalności reakcji na naruszenia ustaw, norm moralnych i porządku publicznego za pomocą wnioskowania na podstawie uporządkowanych kryteriów nakazujących uwzględnić zasadnicze przesłanki wpływające na skutki prawne ww. naruszeń.

\section{§ 7. Nieważność częściowa w systemach common law - przesłanki ogólne}

Podobnie jak w tradycji kontynentalnej, w common law przyjmuje się powszechnie dopuszczalność częściowego utrzymania w mocy skutków prawnych wadliwej umowy poprzez zastosowanie mechanizmów ograniczających zasięg zastosowania sankcji nieważności bezwzględnej (lub analogicznego instrumentu prawnego) tylko do niedopuszczalnych skutków prawnych. Przesłanki nieważności częściowej omawia się przy tym z nieco innej perspektywy; z punktu widzenia możliwości zachowania w ten sposób wykonalności umowy, pomimo konieczności usunięcia z umowy skutków prawnych rozumianych jako niedozwolone części normatywne (doktryna severance, severability) ${ }^{271}$.

$\mathrm{Z}$ reguły kwestia ta poddawana jest analizie przy ocenie zasięgu nielegalności umowy i pożądanego stopnia jej nieegzekwowalności. Należy przez to podkreślić, że ze względu na pewne odrębności w stosowanych sankcjach (nie tylko nieważności bezwzględnej) bardziej precyzyjne jest określenie instytucji severance zbiorem reguł dotyczących utrzymania wykonalności umowy w zakresie dopuszczalnych skutków prawnych.

270 § 356 [Liquidated Damages And Penalties] Damages for breach by either party may be liquidated in the agreement but only at an amount that is reasonable in the light of the anticipated or actual loss caused by the breach and the difficulties of proof or loss. A term fixing unreasonably large liquidated damages is unenforceable on grounds of public policy as a penalty. Powyższe rozwiązanie odpowiada przepisowi § 2-718 The Uniform Commercial Code, dotyczącego umowy sprzedaży. Naruszenie tego przepisu za podstawę sankcji nieważności ab initio uznaje np. E.C. Arkebauer [w:] Negotiating and Drafting Contract Boilerplate, pod red. T.L. Stark, Chicago 2003, s. 228.

271 Również stosowana jest nazwa severability - por. H. Kötz [w: ] Casebook..., s. 315. 
Stanowiska systemów krajowych tradycji common law są zróżnicowane w zakresie identyfikacji poszczególnych kryteriów tej instytucji, od nastawienia bardziej niechętnego do utrzymania umowy w mocy do stosowania skrajnie wręcz elastycznego podejścia. W zasadzie zgodność dotyczy ogólnego założenia tej instytucji. Jeżeli jej zastosowanie jest dopuszczalne, następuje w dwojaki sposób:

1. pierwszym jest możliwość dokonania przez sąd zredukowania zakresu zobowiązania umownego poprzez oddzielenie niedopuszczalnej części umowy,

2. drugim jest uchylenie całego zobowiązania umownego ${ }^{272}$.

W poglądach doktryny kładzie się nacisk na niedopuszczalność sądowego określenia na nowo treści umowy i odejście od tego, co zostało wyrażone formalnie w umowie. Wyróżnia się także ustawowy tryb (statutory severance) ograniczenia sankcji nieważności (lub nieegzekwowalności), jeżeli sama ustawa rozstrzyga, że umieszczenie wadliwej klauzuli nie powoduje nieważności lub nieegzekwowalności całej umowy ${ }^{273}$.

W przypadku trybu sądowego zasadniczo stosowane są trzy główne przesłanki szczegółowe (przesłanki pozytywne) oraz, jak zostało wspomniane powyżej, jednocześnie usunięcie wadliwych części umowy nie może być sprzeczne z dość szeroko rozumianą zasadą porządku publicznego lub dobrymi obyczajami (przesłanka negatywna).

Z perspektywy celu sankcji nieegzekwowalności jest zrozumiałe, że dopuszczalność częściowej ważności nie dotyczy umów nieegzekwowalnych z powodu sprzeczności z normami moralnymi, w tym nielegalnych na gruncie public policy oraz umów nielegalnych ze względu na przestępczy charakter świadczenia, np. oszustwa podatkowe ${ }^{274}$.

W zakresie cech formalnych tej normy sankcjonującej można wskazać na kilka podstawowych przesłanek, istotnie różniących się od podejścia prawa polskiego, w szczególności wywodzącej się z teorii opracowanej w prawie niemieckim - tzw. hipotetycznej woli stron lub redukcji utrzymującej skuteczność.

272 Por. szerzej np. P. Gillies, Concise Contract..., s. 168-169; The Law Commission, Illegal Transactions..., s. 46.

273 Por. szerzej G.H. Treitel, The Law..., s. 209-210, 392. Rozwiązanie takie przewidywała np. sekcja 26 Fair Trading Act 1973 . W takim przypadku akty prawne z reguły posługują się sformułowaniem, że sankcji względem całej umowy nie stosuje się tylko z powodu jednej wadliwej klauzuli.

274 G.C. Cheshire, C.H. Fifoot, M. Furmston [w:] Law of Contract, s. 404; R. Halson, Contract..., s. 230. 
Pierwszą przesłanką pozytywną jest możliwość fizycznego, dosłownego oddzielenia nieważnych postanowień umowy od jej pozostałej części ${ }^{275}$. Jest to zabieg na tyle techniczny, że określa się go regułą „niebieskiego ołówka” (the blue pencil rule $)^{276}$. Jej sens sprowadza się w pewnym uproszczeniu do wykluczenia możliwości dokonania przez sąd ponownego określenia zobowiązania stron względem tego, co zostało wyraźnie przewidziane w umowie. Nacisk kładzie się przy tym na okoliczność, że nie można dokonać zmiany słów lub dodać nowych, które strona składająca oświadczenie woli mogła dokonać ${ }^{277}$. Wydzielenie niewadliwych obowiązków powinno nastąpić bez naruszania sensu i treści umowy ${ }^{278}$. Wyjątkiem jest m.in. dopuszczalność redukcji zakresu zobowiązania w prawie pracy dla strony słabszej (pracownika), jeżeli sąd oceni, że pracownik nierozsądnie zaakceptował zbyt szeroki zakaz konkurencji, a pracodawca działał umyślnie. Wówczas sąd określi ten obowiązek na podstawie wiedzy oraz świadomości praw pracowniczych aż do poziomu prawnie dopuszczalnego. Aksjologicznym podłożem jest częsta w praktyce niedostępność drogi sądowej dla pracowników, przeważnie z powodu obaw przed kosztami procesów ${ }^{279}$.

Wśród przykładów spraw sądowych możliwe jest także doszukanie się rozwiązania podobnego do ilościowej nieważności częściowej, którą przyjęto w sytuacji, gdy jest możliwe precyzyjne określenie wartości zgodnej z prawem części umowy i oddzielenie jej od reszty sprzecznej z prawem ${ }^{280}$.

Uchylenie całego obowiązku, stanowiącego część umowy (elimination of a promise), możliwe jest jedynie, jeżeli nie powoduje to upadku w całości przyczyny umowy (consideration). Innymi słowy określa się tę przesłankę w ten sposób, aby sprzeczny z prawem obowiązek nie formował całej przyczyny umowy i miał jedynie pomocnicze znaczenie w kontekście głównego celu umowy ${ }^{281}$. Jeżeli obowiązek umowny, rozpatrywany w kategoriach częściowej nieważności, jest w zasadzie jedynym obowiązkiem, nierozerwalnie skorelowanym ze

275 W piśmiennictwie, podkreślając techniczną możliwość oddzielenia niedopuszczalnej części umowy, wskazuje się, że pozostała część umowy nie może zostać pozbawiona znaczenia, gdyż wówczas sąd nie będzie uprawniony do zmiany treści umowy - tak np. G. Monahan, Essential Contract Law, wyd. 2, Cavendish 2001, s. 125.

276 J. Beatson, Anson's Law..., s. 400. R. Zimmermann (R. Zimmermann, The Law of Obligations, Roman Foundations of the Civilian Tradition, Oxford 1996, s. 78) wskazat, że tego typu regułę i powściągliwość powinny stosować sądy niemieckie przejawiające rosnącą skłonność do redukowania niedopuszczalnych postanowień umownych do prawnie akceptowalnego poziomu.

277 G.C. Cheshire, C.H. Fifoot, M. Furmston [w: ] Law of Contract, s. 406.

278 Tamże, s. 408.

279 Tak w znanym orzeczeniu Mason v. Provident Clothing \& Supply Co. Ltd. [1913].

280 Por. G.H. Treitel, The Law..., s. 387.

281 Tak m.in. J. Beatson, Anson's Law..., s. 401; G.H. Treitel, The Law..., s. 387. 
wzajemnym zobowiązaniem drugiej strony, wówczas umowa jest w całości nieważna (nieegzekwowalna) ${ }^{282}$.

Trzecim warunkiem jest wspomniana konieczność uniknięcia zmiany przez sąd celu umowy ${ }^{283}$. Nie może być zwłaszcza dodana lub sformułowana od nowa treść umowy, a pozostała jej część musi zachować sens prawny bez żadnych dodatkowych zabiegów ${ }^{284}$. Postulat ten tłumaczy się tym, że nie jest dozwolone zastosowanie częściowej nieważności, jeżeli usunięcie wadliwego postanowienia zmieni całą naturę umowy, tj. nie tylko zostanie zmieniony zakres klauzuli umownej, ale równocześnie zmieni się sama natura kontraktu: zakres i zamiar porozumienia ${ }^{285}$. Przesłanki te są w szczególności aktualne na gruncie umów przekraczających poziom dopuszczalnych ograniczeń konkurencyjnych i wyłączności handlowej (restraint of trade) ${ }^{286}$, gdzie takie niedopuszczalne postanowienie może stanowić główną część klauzuli. Na gruncie tej ostatniej kategorii umów w orzecznictwie przyjmuje się niedopuszczalność utrzymania ważności całej umowy, jeżeli niedozwolone postanowienie zostało celowo zbyt szeroko ujęte w umowie ${ }^{287}$.

Utrzymanie częściowej ważności umowy nie prowadzi do jednolitych następstw w każdej sytuacji. Generalnie obok ważności częściowej umowy i uchylenia jedynie nielegalnej części obowiązków umownych, możliwe są dwa rozwiązania pośrednie. Pierwszym jest jednostronna częściowa nieważność (one-sided severance), która polega na redukcji zobowiązania jednej tylko strony ${ }^{288}$. Drugim rozwiązaniem jest, wraz z zachowaniem częściowej ważności umowy, przeprowadzenie restytucyjnego rozliczenia stron ${ }^{289}$.

Widoczne jest w świetle powyższych uwag, że są to efekty zbliżone do kontynentalnej instytucji redukcji utrzymującej skuteczność, choć w common law $\mathrm{w}$ zasadzie uznaje się dostosowanie treści wadliwej do prawnie dozwolonego zakresu poprzez mniej rygorystyczne stosowanie reguły blue pencil.

Warto zwrócić również uwagę na stanowisko prawa kanadyjskiego. Obok modelu tradycyjnego wypracowano nowe narzędzie dla rozpatrywania niektórych przypadków nielegalności części umowy. W odróżnieniu od tradycyjnej nazwy dodaje się sformułowanie o tzw. hipotetycznym oddzieleniu (notional

282 G.C. Cheshire, C.H. Fifoot, M. Furmston [w: ] Law of Contract, s. 405.

283 Tak m.in. P. Richards, Law..., s. 300.

284 K. Smith, D.J. Keenan’s English..., s. 366.

285 Tak m.in. G.H. Treitel, The Law..., s. 389.

286 W kwestii umów, które zabraniają lub regulują możliwość prowadzenia działalności konkurencyjnej lub narzucających wyłączność handlową (contracts restraint of trade) - por. szerzej np. tamże, s. 346-369.

287 J. Beatson, Anson's Law..., s. 402; K. Smith, D.J. Keenan's English..., s. 366.

288 J. Beatson, Anson's Law..., s. 403.

289 Tamże, s. 403. 
severance). Dopuszczalność zastosowania severance sprowadza się do konieczności zachowania przesłanek, które są połączeniem klasycznej reguły blue pencil oraz kryteriów subiektywnych:

a. pozostała część umowy musi być tzw. rdzeniem porozumienia, mieć samodzielność i przydatność regulacyjną dla stron,

b. według obiektywnego kryterium wyrażonego w generalnej klauzuli rozsądku zachodzić powinna możliwość przypisania stronom zamiaru utrzymania porozumienia bez oddzielonych postanowień,

c. możliwe powinno być dokonanie prostego oddzielenia niedopuszczalnego postanowienia, bez jego zmiany lub dodawania umowie nowej treści (w tym ostatnim przypadku podkreśla się wagę tradycyjnej reguły blue pencil) ${ }^{290}$.

Doktryna sprowadza działanie tej odmiany częściowej nieważności do zabiegu redukcji ${ }^{291}$. Redukcja jest sposobem reakcji, dopuszczalnym $w$ razie zobowiązań przekraczających poziom określony przepisami. Wskazuje się na problem oceny, czy dzięki mechanizmowi redukcji możliwe jest zwiększenie zobowiązania dla osiągnięcia minimum ustawowego ${ }^{292}$. Taką możliwość przewiduje prawo Nowej Zelandii w sekcji 76 Contract and Commercial Law Act 2017 (przeniesionego z sekcji 7 Illegal Contracts Act 1970), zgodnie z którym sąd może również w taki sposób zmienić treść umowy.

Nowe podejście do sankcji częściowej nieważności z powodu nielegalności umowy zapoczątkowało orzeczenie Sądu Najwyższego Kanady w sprawie New Solutions Financial Corporation v. Transport North American Express Inc. z roku $2004^{293}$. W piśmiennictwie kanadyjskim wyjaśnia się, że szczególnie rażąco wadliwe umowy, niemal o celu już kryminalnym, będą jednak uznane za nieważne ab initio ${ }^{294}$.

W innych orzeczeniach przyjmuje się, obok rozwiązania klasycznego, konieczność ustalenia czy cel zakazu ustawowego może być zachowany tylko przez odmowę przyznania roszczeń kontraktowych, restytucyjnych lub odszkodowawczych. Przesunięto akcent dla judykatury w stronę przyjmowania dopuszczalności środków ochrony prawnej ex contractu (lub innych) jako zasady ${ }^{295}$.

290 The British Columbia Law Institute, Report on Relief Under Legally Defective..., s. 16.

291 M. Cumyn, Nullity of Contracts in Québec Law..., s. 7, 10.

292 Tamże, s. 7.

293 Por. bliżej The British Columbia Law Institute, Report on Relief Under Legally Defective..., s. 22, passim.

294 Tamże, s. 22.

295 Tamże, s. 22. Autorzy raportu dopuszczają możliwość szerokiego zastosowania koncepcji notional severance do różnych typów umów, w tym ograniczeń działalności konkurencyjnej. 
Również w prawie amerykańskim odmiennie niż to przyjmuje się na gruncie tradycyjnej doktryny severance, dopuszcza się zmianę umowy w przypadku jej częściowej nieważności. Możliwość utrzymania ważności częściowej umowy poszerza się dodatkowo zastosowaniem kryteriów również o zabarwieniu subiektywnym. Punktem wyjścia jest zasada rozsądku, która pozwala na odstąpienie od klasycznych przesłanek reguły blue pencil. Odstąpienie od tej reguły wyrażone zostało w The Restatement (Second) of Contracts, które dają prymat mechanizmowi, dzięki któremu sąd może zmienić nieważne postanowienie umowne do stopnia rozsądnego w danych okolicznościach i utrzymać ważność oraz skuteczność prawną tak zmodyfikowanej klauzuli umownej. Należy podkreślić, że w orzecznictwie i nauce wskazuje się, że celowe jest ograniczenie ryzyka przekroczenia sensu tej regulacji przez przyjęcie obowiązku udowodnienia, że nieważne postanowienia umowne były $\mathrm{w}$ czasie zawarcia umowy przyjęte $\mathrm{w}$ dobrej wierze i zgodnie z zasadami uczciwego postępowania ${ }^{296}$.

Należy także wskazać, że zasady The Restatement (Second) of Contracts, zgodnie z doktryną severability, przyjmują dwa podejścia do problemu częściowej nieważności umowy (a precyzyjniej: sankcji nieegzekwowalności częściowej), które są uzależnione od kryterium podzielności i niezależności zobowiązań umownych stron, w szczególności odpowiadających sobie obowiązków, które umożliwiają częściowe wykonanie umowy.

Warunkiem ogólnym dopuszczalności utrzymania częściowej ważności (wykonalności), podobnie jak w doktrynie angielskiej, jest nienaruszenie - przez wykonanie umowy - interesu publicznego, nawet w sposób pośredni. Zwraca się uwagę na konieczność ustalenia czy wykonanie takiej umowy nie jest częścią większego planu, mającego na celu naruszenie interesu publicznego ${ }^{297}$.

Podzielność zobowiązań umownych zachodzi, jeżeli umowa może zostać podzielona na odrębne i niezależne od siebie wzajemne uzgodnienia (klauzule umowne). Jeżeli nie jest możliwe dokonanie podziału umowy i wydzielenie części zgodnej z prawem, to sąd może mimo to zachować ważność pozostałej części umowy. W prawie amerykańskim zabieg ten określa się doktryną „niezbędnej części umówionej transakcji” (essential part of the agreed exchange). Odwołuje się do niej § 184 pkt 1 The Restatement (Second) of Contracts ${ }^{298}$. Zgodnie z tym przepisem, sąd może zachować skuteczność prawną niewadliwej części umowy wyłącznie na korzyść strony, której nie dotyczy poważne naruszenie zasad porządku i interesu publicznego, będącego podstawą sankcji

296 Por. C.J. Levin, A.R. Brown [w:] Negotiating and Drafting Contract Boilerplate, pod red. T.L. Stark, New York 2003, s. 546 wraz z przywoływanym tam orzecznictwem i piśmiennictwem.

297 Tamże, s. 542-543.

298 § 184 (When Rest of Agreement Is Enforceable). 
nieegzekwowalności. Następnie warunkiem jest, aby świadczenie wynikające z nieegzekwowalnej części umowy nie było podstawową częścią transakcji. Komentarz do tej reguły wyjaśnia, że ustalenie, czy świadczenie jest podstawową częścią uzgodnionej transakcji zależy od ocenianej subiektywnie jego doniosłości w świetle całokształtu uzgodnień dokonanych pomiędzy stronami ${ }^{299}$. Na mocy tych samych przesłanek, zgodnie z pkt 2 ww. przepisu, możliwe jest zachowanie ważności części postanowienia umownego, jeżeli strona dochodząca wykonania tego postanowienia umowy zawarła je w dobrej wierze i zgodnie ze standardami uczciwego i rozsądnego postępowania w obrocie ${ }^{300}$.

W tym zakresie komentarz jako przykład podaje omyłkowe umówienie się o odsetki przekraczające prawnie dopuszczalną granicę. Jeżeli strony nie wiedziały o tym przekroczeniu, wówczas dokonana będzie redukcja do poziomu dopuszczalnego maksimum. Jeżeli pożyczkodawca wiedziałby o tej wadliwości, cała umowa byłaby uznana za nieważną ${ }^{301}$. Wynika $z$ tego zasada odmowy zachowania w mocy umowy dla podmiotu działającego świadomie sprzecznie z prawem.

Siłą rzeczy skrótowe przedstawienie przesłanek (kwestii proceduralnych) nieważności częściowej pozwala jednak zauważyć, że paradoksalnie w systemie prawa precedensowego bardziej zwalcza się nadmierną uznaniowość i promuje mniejszą interwencję sędziowską w treść umowy aniżeli w niektórych systemach ius civile, w szczególności uznaniowość wynikającą z konstrukcji hipotetycznej woli stron lub redukcji utrzymującej skuteczność.

\section{§ 8. Uwagi ogólne o wpływie sankcji sędziowskiej wg common law na prawo polskie}

\subsection{Sankcja sędziowska structured discretion $\mathrm{w}$ projekcie polskiego Kodeksu cywilnego z 2015 r.}

W prawie polskim nastąpił istotny przełom w postrzeganych - jako fundamentalne - cechach formalnych sankcji nieważności bezwzględnej. W projekcie I Księgi Kodeksu cywilnego z 2015 r. pojawiła się propozycja ustawowego unormowania structured discretion. Jest to istotna zmiana podejścia do rozumienia

299 Por. tamże, s. 544.

300 Por. $\$ 184$ (2) A court may treat only part of a term as unenforceable under the rule stated in Subsection (1) if the party who seeks to enforce the term obtained it in good faith and in accordance with reasonable standards of fair dealing.

301 Por. m.in. tamże, s. 543-545. 
cech formalnych normy sankcjonującej stanem nieważności z mocy prawa. Zaproponowano sędziowską kompetencję do wskazania (w razie milczenia ustawy w tym zakresie) w konkretnej sprawie cech formalnych normy sankcjonującej oraz określenie, czy i w jakim zakresie powinna być zastosowana sankcja nieważności (bezwzględnej).

W propozycji z 2015 r. widoczne jest, że zaaprobowano pewien kierunek regulacji sankcji sędziowskiej w cywilistyce kontynentalnej. Komisja Kodyfikacyjna $\mathrm{w}$ art. $71 \S 1$ zaproponowała cechy formalne normy sankcjonującej, jak również wskazano, jakie racje norm merytorycznych (sankcjonowanych) powinny być uwzględniane dla określenia sankcji właściwej (art. 71 § 2 projektu z 2015 r.). Jednocześnie zmodyfikowano dotychczasowe formy structured discretion zaadaptowane w PECL lub DCFR. Wydaje się, że może być to rozwiązanie bardziej skuteczne i wspierające efektywność prawa w porównaniu do prawa modelowego lub rozwiązań systemów common law ${ }^{302}$.

Porównując unormowanie DCFR z art. 71 § 2 projektu z 2015 r., należy zwrócić uwagę na zupełnie inne zasady ustalania zasięgu działania sankcji względem skutków prawnych, a także nieco odmienne kryteria oceny sankcji właściwej (proporcjonalnej). Cechy formalne normy sankcjonującej: kreowanie stanu prawnego inaczej reguluje art. $71 \S 1$ ust. 1 projektu w stosunku do ww. europejskich projektów. Jeśli chodzi o cechy formalne normy sankcjonującej stanem nieważności, to PECL oraz DCFR zawierają odwołanie do czterech cech sankcji statuujących, które skutki prawne będą w mocy i w jakim zakresie. Zgodnie $\mathrm{z}$ art. 15:102 § 2 PECL: umowa może zostać uznana za skuteczną w pełnym zakresie, za częściowo skuteczną, za bezskuteczną lub podlegać zmianie. Podobnie reguluje zakres sędziowskiej uznaniowości art. II-7:302 (2) DCFR: sąd ma następujące możliwości: uznać umowę za ważną, unieważnić ze skutkiem wstecznym umowę, w całości lub części, lub zmienić umowę lub jej skutki prawne.

Propozycja projektu I Księgi Kodeksu cywilnego z 2015 r. w zasadzie przy odpowiednim rozumieniu czterech powyższych środków pozwala na osiągnięcie co najmniej takich rezultatów działania sankcji. Ponadto jest jednak proceduralnie znacznie bardziej przydatna w poszukiwaniu, jak powinna kształtować się

302 Należy dodatkowo przypomnieć duże podobieństwo do § 178 The Restatement (Second) of Contracts, który przy ocenie, czy zachodzi interes za nadaniem wykonalności prawnej części umowy wymaga uwzględnienia następujących okoliczności: 1. Usprawiedliwione oczekiwania stron, 2. Każda strate, która powstałaby $w$ razie odmowy nadania wykonalności prawnej, 3. Każdy rodzaj interesu publicznego, jaki przemawiałby za wykonalnościa prawna danego postanowienia umowy, 4. Wage zasady porządku publicznego będacej uzasadnieniem przepisu lub orzeczenia sądu, 5. Prawdopodobieństwo, czy odmowa nadania wykonalności prawnej umowie będzie promowata zasadę porzadku publicznego, czy raczej wykroczy poza cel i uzasadnienie tej zasady, 6. Powage niewłaściwego postępowania stron oraz stopień jego umyślności, 7. Bezpośredniość zwiazków pomiędzy niewtaściwym zachowaniem stron a postanowieniem umowy. 
norma sankcjonująca. W tym ostatnim aspekcie propozycja zmian w polskim kc jest mocniej zbliżona do niektórych regulacji common law. Na przykład w kanadyjskim projekcie Uniform Illegal Contracts Act z 2008 r. przewiduje się określenie skutków prawnych przez sędziego w przyznaniu ochrony w przypadku nielegalnej umowy na mocy sekcji 5 (1): restytucja; odszkodowanie; rozłożenie straty wynikającej z powstania, istnienia lub wykonania umowy (apportionment of a loss); odszkodowanie od strony ponoszącej winę; deklaracja; nakazanie nabycia majątku przez jakąkolwiek osobę lub nakazanie przelewu lub rozporządzenia własności na inną osobę. Dodatkowo, zgodnie z sekcją 5 (1) pkt (g), jeżeli sąd uzna, że: zgodnie z podpunktem (i) umowa byłaby rozsądna i zgodna $z$ prawem, jeżeli: (A) usunięto by jedno lub więcej postanowień umowy lub: (B) całej umowie jako lub jednemu lub więcej z jej postanowień przyznano by tylko ograniczoną skuteczność, biorąc pod uwagę tylko ograniczony jej efekt, oraz zgodnie z pkt (ii) skreślenie lub redukcja nie wpłynęłyby na zmianę umowy stron do tego stopnia, że byłoby nieuzasadnione nadanie mocy obowiązującej tak zmienionej umowie; to wówczas sąd może wydać nakaz zmiany umowy w celu dokonania redukcji lub ograniczenia, oraz aby zmieniona umowa została wykonana w sposób zgodny z prawem, który określi sąd.

Na mocy pkt (h) sekcji 5 (1) ww. projektu z 2008 r. sąd może przyznać wszelkie inne środki prawne (relief), które mógł udzielić na podstawie prawa powszechnego lub słuszności, gdyby umowa nie była nigdy umową nielegalną. Środki te mogą być łączone, mają przywrócić strony do ich początkowej pozycji albo przyznać odszkodowanie. Podkreślenia wymaga, że w żadnym przypadku nie jest możliwe wliczenie do wartości roszczenia utraconych zysków. Możliwe są ponadto dalsze zabiegi moderujące wartość roszczeń [por. sekcja 5 (2)-(3) projektu Uniform Illegal Contracts Act z 2008 r.].

Podobnie działanie normy sankcjonującej przedstawia się w przywołanym rozwiązaniu prawa Nowej Zelandii (Contract and Commercial Law Act 2017, sekcja 76). Przepis ten podaje cechy formalne normy sankcjonującej, ale od strony właściwej dla podejścia common law łączącego skutki prawne, które wynikać mogą z zastosowania sankcji z przyznaniem określonych roszczeń lub środków ochrony prawnej.

Projekt polskiej I Księgi Kodeksu cywilnego ujmuje to w sposób następujący (art. 71 § 1), a sankcja inna niż nieważność może polegać w szczególności na:

1. nieważności czynności prawnej ze skutkiem na przyszłość;

2. obowiązywaniu w miejsce postanowienia sprzecznego z normą postanowienia wynikającego z ustawy lub z dobrych obyczajów albo postanowienia najbliższego woli wyrażonej w treści czynności prawnej;

3. braku możliwości dochodzenia roszczenia;

4. bezskuteczności czynności lub jej części do czasu dopełnienia dodatkowej przesłanki, w tym uzyskania zgody oznaczonej osoby; 
5. przysługiwaniu jednej lub obu stronom uprawnienia do odstąpienia albo wypowiedzenia stosunku prawnego;

6. bezskuteczności czynności względem osoby chronionej naruszoną normą;

7. odpowiedzialności odszkodowawczej jednej ze stron względem osób, których interesy były chronione naruszoną normą.

Powyższy katalog, jako katalog otwarty, stanowi prawną podstawę do strukturalnej dyskrecjonalności w celu wyszukania takiej formy zablokowania lub modyfikacji skutków prawnych, aby możliwe było uniknięcie ich całkowitej eliminacji. Pozycją wyjściową w efekcie jest uprzednie stwierdzenie przez sąd celowości zachowania części zamierzonych ${ }^{303}$ skutków prawnych w mocy oraz potrzebę zastosowania zasady reakcji proporcjonalnej do danego naruszenia.

Następnie, w sposób oparty na instrukcyjnym wykazie środków i form, następuje dobór sankcji przez sąd zgodnie z zasadą proporcjonalności. Dobór cech formalnych normy sankcjonującej opiera się ściśle na założeniach aksjologicznych naruszonych norm merytorycznych i umiejętności ich uchwycenia w konkretnej sprawie stanowić będą o powodzeniu w praktyce tak ułożonej uznaniowości.

W uzasadnieniu projektu wyjaśnia się m.in., że strukturalną uznaniowość wprowadzono w celu ułatwienia wykładni i zwiększenia przewidywalności rozstrzygnięć odnośnie do rozumienia cech formalnych normy sankcjonującej304; Komisja Kodyfikacyjna za wskazane uznała sformułowanie dodatkowych wskazówek odnośnie do czynników, które należy uwzględnić dla doboru, która sankcja jest właściwa (art. $71 \S 2$ projektu) ${ }^{305}$. Warto uwagę zwrócić, że w uzasadnieniu podkreśla się, że wskazówki z art. 71 §1-2 mają charakter przykładowy, nie zmierzają zatem do wprowadzenia zasady numerus clausus typów sankcji i okoliczności decydujących o ich właściwości.

Przy takim założeniu stwierdzenie, że intencją projektu nie jest otwarcie drogi do ustalania sankcji „sędziowskiej”, jako sankcji „szytej na miarę”, stosownie do okoliczności faktycznych konkretnego przypadku ${ }^{306}$, wydaje się nieco zaskakujące. Ograniczenie uznaniowości sędziowskiej nie wydaje się drogą do wykluczenia samej koncepcji sankcji sędziowskiej. Wyjaśniając, należy podkreślić, że w ramach podwalin reformy illegality w krajach common law pozostawienie sędziowskich kompetencji było oczywiste. Bardziej chodziło o ukierunkowanie orzecznictwa, spowodowanie automatyzmu w rozważaniu pewnego

$303 \mathrm{~W}$ tym skutków prawnych przypisywalnych na mocy normy prawnej de lege lata wynikającej z art. $56 \mathrm{kc}$.

304 R. Trzaskowski [w:] Kodeks cywilny. Księga I..., s. 104.

305 Tamże, s. 104.

306 Tamże, s. 104. 
minimalnego katalogu istotnych każdorazowo okoliczności. Celem było spowodowanie w orzekaniu odruchu poszukiwania racjonalnej formuły promowania zasady reakcji proporcjonalnej do danego naruszenia i wyważenia tych założeń polityki stosowania prawa $\mathrm{w}$ danej decyzji przez sędziego. To ostatnie zmierzało do eliminacji nazbyt mechanicznego orzekania, które jako mało elastyczne powodowało szereg rażących przykładów nieproporcjonalności sankcji w orzecznictwie. Wciąż jednak zachowano całkowitą uznaniowość sędziowską w ramach common law (notabene pomimo zarzucenia w Wielkiej Brytanii reformy w prawie umów, w orzecznictwie zaczęto wykorzystywać intencje projektów, dorobek prawie dziesięcioletnich uzgodnień, co samo w sobie obecnie uważa się za zapowiedź ewolucyjnej zmiany w tradycyjnym sankcjonowaniu nielegalności ${ }^{307}$.

Polska propozycja z 2015 r. wydaje się zatem trafnie - i proporcjonalnie do skrajnych rozwiązań stosowanych obu ww. tradycji prawnych - regulować zarówno możliwość modyfikacji normy sankcjonującej, jak też wprowadza nowoczesny model normatywny w celu - co było inspiracją także dla reform illegality - promowania reakcji proporcjonalnej do danego naruszenia. Proporcjonalność i elastyczność sankcji tylko ramowo ograniczono poprzez wskazanie przez sąd ustawowego katalogu merytorycznych okoliczności niezbędnych do wszechstronnego i pogłębionego rozstrzygnięcia sprawy.

\subsection{Okoliczności materialne kreujące cechy formalne normy sankcjonującej w projekcie I Księgi Kodeksu cywilnego z 2015 r.}

Jest to najpoważniejsze wyzwanie dla koncepcji sankcji opartej na podejściu strukturalnym - ograniczonym proceduralnie. W projekcie I Księgi Kodeksu cywilnego z 2008 r. nie zdecydowano się na pełną recepcję rozwiązań europejskiego prawa modelowego lub rozwiązań stosowanych w niektórych krajach common law. Jednak w 2015 r. dokonano gruntownej zmiany pierwotnej propozycji projektu I Księgi Kodeksu cywilnego z 2009 r. Zgodnie z art. 71 § ust. § 2, ustalając sankcję właściwą ze względu na cel naruszonej normy, sąd powinien rozważyć w szczególności:

1. interesy chronione przez naruszoną normę, a także godne ochrony interesy stron umowy i osób trzecich;

2. inne konsekwencje prawne, jakie pociąga za sobą naruszenie prawa;

3. świadomość albo brak świadomości naruszenia ustawy lub dobrych obyczajów po stronie osób dokonujących czynności;

4. czy czynność prawna zobowiązuje do zachowania zakazanego przez ustawę lub dobre obyczaje;

307 Por. The Law Commission, The Illegality Defence..., s. VII. 
5. czy sprzeczność czynności z ustawą lub dobrymi obyczajami jest wynikiem nadużycia przez jedną ze stron silniejszej pozycji kontraktowej;

6. czy wykonanie obowiązków stron prowadzi do rezultatu, któremu miała zapobiegać naruszona norma.

Źródło inspiracji powyższej propozycji znajdziemy w PECL i DCFR: zgodnie $z$ art. 15:102 (2) PECL decyzja sądu o sankcji, która powinna być proporcjonalna i odpowiednia do naruszenia, musi uwzględniać:

1. cel naruszonego przepisu,

2. kategorię osób, które przepis ma chronić,

3. inne sankcje, które mogą wynikać z naruszenia tego przepisu,

4. stopień naruszenia,

5. charakter umyślny lub nieumyślny naruszenia,

6. związek między umową a naruszeniem.

Jednocześnie praźródeł propozycji prawa modelowego należy dopatrywać się w prawie anglosaskim i wspomnianym wpływie wywartym w toku prac nad prawem modelowym. Podobnie powyższe okoliczności reguluje się w prawie Nowej Zelandii z 2017 r. (poprzednio 1970 r.), w 178 amerykańskich The Restatement (Second) of Contract z 1981 lub kanadyjskim projekcie z 2008 r.

Projekt polskiej I Księgi Kodeksu cywilnego z 2015 r. oraz art. 15:102 (2) PECL i art. II-7:302 (3) DCFR są w zasadzie identyczne. Porównanie tych przepisów skłania do wniosku, że zachowuje się mimo wszystko w tekście art. 71 § 2 pkt 1-3 projektu z 2015 r. trzon założeń prawa modelowego.

Polska propozycja jednak w 3 przypadkach wychodzi poza prawo modelowe oraz różni się od niego, podobnie jak prawo ww. systemów common law, rozbudowaniem czynników istotnych dla dopasowania sankcji przez sędziego do danego przypadku.

W polskim projekcie mamy do czynienia z odejściem od badania kryterium stopnia naruszenia na rzecz rozłożenia akcentów przez wskazanie w pkt 4-6 okoliczności dotyczących zarówno stopnia naruszenia, jak też uregulowania, że sankcja uzależniona jest od statusu legalności świadczenia strony (pkt 4) ${ }^{308}$. Jeżeli sprzeczność czynności z ustawą lub dobrymi obyczajami jest wynikiem nadużycia przez jedną ze stron silniejszej pozycji kontraktowej (pkt 5), w uzasadnieniu podkreśla się możliwość orzeczenia reformatoryjnej zmiany w umowie, w celu związania strony nadużywającej swej pozycji umową zmienioną na jej niekorzyśćc ${ }^{309}$. W przypadku art. $71 \S 2$ pkt 6 projektu z 2015 r. w uzasadnieniu trafnie zwrócono uwagę na konieczność unikania nieproporcjonalnych sankcji w razie naruszenia np. wymogów technicznych realizacji umowy ${ }^{310}$.

308 R. Trzaskowski [w:] Kodeks cywilny. Księga I..., s. 109-110.

309 Tamże, s. 110.

310 Tamże, s. 110 
Dla oceny projektu warto spojrzeć na pewien aspekt kanadyjskiego Uniform Illegal Contracts Act z 2008 r. W zakresie kognicji sądu w orzekaniu o skutkach nielegalności w sekcji 6 ww. projektu znajduje się pkt h, który brzmi, że o sankcji sędzia może orzec także wedle „innych czynników, jakie sąd uzna za doniosłe". Pokazuje to, że tylko co do zasady w modelu structured discretion mamy ograniczenie kompetencji sądu, jednak nie jest to zakaz bezwzględny sąd ma prawo w uzasadnionych przypadkach wskazać na inne czynniki, które wpłynęły na treść orzeczenia.

Podobnie należy rozumieć propozycje art. 71 projektu, gdzie structured discretion ma przede wszystkim służyć idei realizacji naturalnej sprawiedliwości poprzez prawidłowe procedury (sprawiedliwość proceduralna) ${ }^{311}$. Wówczas w każdym przypadku sąd powinien w uzasadnieniu wskazać, co uwzględnił, a co pominął z katalogu art. 70-71 projektu z $2015 \mathrm{r}$.

\section{§ 9. Uwagi końcowe}

Przegląd regulacji common law odpowiadających sankcji nieważności bezwzględnej wydaje się wspierać zarówno rozwiązania projektu zmian kc w prawie polskim, jak też dostarczać kolejnych interesujących zagadnień do przeanalizowania w przypadku powrotu do prac legislacyjnych. Szczególnie istotne jest zwrócenie uwagi na przewrotność jednopłaszczyznowego promowania zasady proporcjonalności sankcji prowadzących do stanu nieważności. Warto przy tym uwzględnić doświadczenia krajów, gdzie structured discretion wywołała pierwsze problemy praktyczne, co np. spowodowało zaprzestanie prac nad reformą w Wielkiej Brytanii. Tej kwestii nie oceniono jeszcze w piśmiennictwie europejskim w sposób pogłębiony i wydaje się, że będzie to centralny punkt do zrewidowania założeń nowej kodyfikacji w tym zakresie.

Nie ulega jednocześnie wątpliwości, że dostrzeżenie znaczenia dla systemu prawa prywatnego zasady proporcjonalnej reakcji na dane naruszenie wytycza podstawowy kierunek modyfikacji tradycyjnego podejścia do tzw. nieważności z mocy prawa - sankcji nieważności bezwzględnej. Być może pozwoli to na wprowadzenie istotnych zmian do teorii nieważności czynności prawnej.

W common law widoczne są dość wyraźne tendencje do omijania problemów, które w prawie kontynentalnym dzięki terminologii ustawowej wywołują ogromne zastrzeżenia $\mathrm{z}$ punktu widzenia zasady efektywności systemu prawa. Większość z tych wyzwań zaadresowano w dobie Common Frame of Reference

$311 \mathrm{~W}$ sprawie sprawiedliwości proceduralnej i jej pewnych konotacji dla prawa prywatnego, por. T.T. Koncewicz, Poszukując modelu sprawiedliwości proceduralnej w prawie wspólnotowym. Mit czy rzeczywistość?, Warszawa 2009, s. 82 i nn. 
i prac nad poprawkami do pierwotnego projektu I Księgi Kodeksu cywilnego. Pozostaje jednak kwestia oceny, czy de lege ferenda nie powinno się postulować rezygnacji z rozwiązań opierających się wyłącznie na jednym słowie „nieważność", na rzecz korzystania z bardziej rozbudowanej regulacji normatywnego modelu nieważności bezwzględnej oraz pozostałych „sankcji” prowadzących do stanu nieważności skutków prawnych.

Dorobek common law pokazuje, że podobnie jak w krajach ius civile lakoniczna terminologia $\mathrm{w}$ rozwiązaniach normatywnych wywiera bardzo negatywny wpływ na skuteczność i efektywność prawa. Skłonność do tworzenia syntetycznych i lakonicznych modeli normatywnych generuje spory w nauce i orzecznictwie. W tym kontekście warto postulować rezygnację z ontologicznego rozumienia nieważności na rzecz stricte normatywnego oraz konwencjonalnego zdefiniowania tego terminu (szczególnie w kontekście dwupoziomowego zakresu pojęciowego nieważności).

Warto zwrócić uwagę, że rosnąca rola ustawowych ograniczeń autonomii woli w prawie prywatnym powoduje wzrost ryzyka niezgodności z przepisami prawnymi, rośnie zatem skala problemu tradycyjnego stosowania nieważności bezwzględnej, a tym samym ryzyka odejścia od zasady reakcji proporcjonalnej.

Nie należy tracić z pola widzenia reakcji common law na naruszenia prawa lub moralności, gdy przywrócenie stanu poprzedniego mogłoby promować kolejne naruszenia albo oznaczać brak ryzyka dla podmiotów działających celowo niezgodnie z prawem. Surowe podejście jest w szczególności wskazane w celu uniknięcia sytuacji, gdy restitutio in integrum w praktyce oznacza dla podmiotu odpowiedzialnego za naruszenie brak sankcji. Zachęcać to może do dalszego łamania prawa lub norm pozaprawnych.

W kręgu anglosaskim przewaga podejścia procesowego nieco mityguje takie ryzyko, dla systemów ius civile jedynym rozwiązaniem jest adaptacja sankcji sędziowskiej oraz przejście na konwencjonalne definiowanie zakresu pojęciowego terminologii dotyczącej systemu sankcji wadliwych czynności prawnych. Powinno to być połączone $\mathrm{z}$ większym zaangażowaniem ustawodawcy w tworzenie przepisów z precyzyjnie określoną sankcją za ich naruszenie. 


\section{Bibliografia}

Andrews N., Arbitration and Contract Law, Cham 2015.

Atiyah P.S., Adams J.N., MacQueen H.L., Sale of Goods, wyd. 11, Harlow 2005.

Baloch T.A., Unjust Enrichment And Contract, Oxford 2009.

Beatson J., Anson's Law of Contract, wyd. 27, Oxford 1998.

Bebchuk L.A., Ben-Shahar O., Precontractual Reliance, „The Journal of Legal Studies" 2001, vol. 30, nr 6 .

Beckmann R.M., Nichtigkeit und Personenschutz. Parteibezogene Einschränkung der Nichtigkeit von Rechtsgeschäften, Tübingen 1998.

Bierć A., Zarys prawa prywatnego. Czesść ogólna, Warszawa 2012.

Birks P., Recovering Value Transferred Under an Illegal Contract, „Theoretical Inquiries in Law" 2000.

Burrows A., A Restatement of The English Law of Contract, Oxford 2016.

Casebook On the Common Law of Europe. Contract Law, red. H. Beale, D. Tallon, L. Bernardeau, R. Williams, Oxford 2002.

Chen-Wishart M., The Nature of Vitiating Factors in Contract Law [w:] Philosophical Foundations of Contract Law, red. P. Saprai, G. Klass, G. Letsas, Oxford 2014.

Cheshire G.C., Fifoot C.H., Furmston M., Law of Contract, wyd. 11, London 1986.

Chitty on Contracts, vol. 1, General Principles, pod red. H.G. Beale'a, wyd. 31, London 2014.

Corbin A.L., Corbin on contracts. One volume edition, St. Paul 1952.

Corrin Care J., Contract Law in the South Pacific, Cavendish 2001.

Cumyn M., Nullity of Contracts in Québec Law, An Overview And Comparison With The Common Law of Illegal Contracts, Saskatchewan 2004, http://www.ulcc.ca.

Drobnig U., General Principles of European Contract Law [w: International Sale of Goods: Dubrovnik Lectures, red. P. Sarcevic, P. Volken, Oceana 1986, http:// www.cisg.law.pace.edu.

Erbacher S., Australian Restitution Law, wyd. 2, Cavendish 2002.

European Contract Law, Materials for a Common Frame of Reference: Terminology, Guiding Principles, Model Rules, red. B. Fauvarque-Cosson, D. Mazeaud, München 2008.

Gallagher E.G., The Law of Suretyship, Chicago 2000.

Gerven W. van, The Concept of Provisional Validity. The Doctrine of Nullity Refined [w:] Ius Privatum Gentium, Festschrift für Max Rheinstein, t. II, red. E. von Caemmerer, M. Rheinstein, S. Mentschikoff, K. Zweigert, Tübingen 1969.

Gutowski M., Bezskuteczność czynności prawnej, wyd. 2, Warszawa 2017.

Gutowski M., Nieważność czynności prawnej, wyd. 4, Warszawa 2017.

Gutowski M., Wzruszalność czynności prawnej, Warszawa 2010. 
Halberda J., Amerykańskie prawo bezpodstawnego wzbogacenia w Restatement z 2011 r., „Kwartalnik Prawa Prywatnego” 2013, nr 4.

Halberda J., Historia angielskich quasi-kontraktów a zasada bezpodstawnego wzbogacenia, „Państwo i Prawo” 2012, nr 1.

Halberda J., Historia zobowiazań quasi-kontraktowych w common law, Kraków 2012.

Halson R., Contract Law, Harlow 2001.

International Encyclopedia of Comparative Law, Vol. VII: Contracts in General, red. K. Zweigert, U. Drobnig, Tübingen-Dordrecht 1981.

Kodeks cywilny. Księga I. Część ogólna. Projekt Komisji Kodyfikacyjnej Prawa Cywilnego przyjęty w 2015 r. z objaśnieniami opracowanymi przez członków zespołu problemowego KKPC, pod red. P. Machnikowskiego, Warszawa 2017.

Kostritsky J.P., llegal Contracts and Efficient Deterrence: A Study in Modern Contract Theory, „Iowa Law Review” 1988, vol. 74.

Księżak P., Bezpodstawne wzbogacenie. Art. 405-414 KC Komentarz, Warszawa 2007.

Księżak P., Świadczenie niegodziwe, Warszawa 2007.

Law Reform Committee (Singapur), Relief from Unenforceability of Illegal Contracts and Trusts, publ. www.agc.gov.sg, [dostęp 5.7.2002].

Leigh Anenson T., Limiting Legal Remedies: An Analysis of Unclean Hands, „Kentucky Law Journal” 2010, vol. 99.

Łętowska E., Sankcje w prawie cywilnym - zarys problemu, „Monitor Prawniczy” 2013, nr 19.

Maddaugh P.D., McCamus J.D., The Law of Restitution, Aurora [Ontario] 2004.

Malsberger B.M, Covenants Not to Compete. A State-By-State Survey, wyd. 5, vol. 1, Arlington 2006.

Mann R.A., Roberts B.S., Smith and Roberson's Business Law, Mason [Ohio] 2005.

Markesinis B.S., Unberath H., Johnston A., The German Law of Contract: A Comparative Treatise, wyd. 2, London 2006.

McCamus J.D., The Restatement (Third) of Restitution and Unjust Enrichment, „Canadian Bar Review” 2011, vol. 90, nr 2.

McKendrick E., Contract Law, wyd. 3, London 1997.

Monahan G., Essential Contract Law, wyd. 2, Cavendish 2001.

Negotiating and Drafting Contract Boilerplate, pod red. T.L. Stark, Chicago 2003.

Principles, Definitions and Model Rules of European Private Law. Draft Common Frame of Reference (DCFR), Full Edition, red. Ch. Von Bar, E. Clive, [b.m.] 2009.

Radwański Z., Jeszcze w sprawie bezwzględnie nieważnych czynności prawnych, „Państwo i Prawo" 1986, nr 6.

Raghavan K., Failure of Consideration as a Basis for Quantum Meruit Following a Repudiatory Breach of Contract, „Monash University Law Review” 2016, vol. 42, nr 1.

Rau A.S., Separability in the United States Supreme Court, „U of Texas Law, Public Law Research Paper" 2006, no 102. 
Richards P., Law of Contract, Harlow 2005.

Schaefer J.A., Beyond a Definition: Understanding the Nature of Void and Voidable Contracts, „Campbell Law Review” 2010, vol. 33, nr 193.

Skorupa P., Normatywne modele sankcji nieważności bezwzględnej a nieistniejąca czynność prawna, „Studia Prawnicze” 2010, z. 1.

Smith L., Common Law and Equity in R3RUE (February 2, 2011), „Washington and Lee Law Review" 2011, Vol. 68.

Stone R., Devenney J., The Modern Law of Contract, wyd. 11, Cavendish 2015.

Stone R., The Modern Law of Contract, wyd. 6, Cavendish 2005.

Swadling W.J., The Role of Illegality in the English Law of Unjust Enrichment [w:] Unjustified Enrichment. Key Issues in Comparative Perspective, D. Johnston, pod red. R. Zimmermanna, Cambridge [Wlk. Bryt.] 2002.

System prawa prywatnego, Prawo cywilne - część ogólna, t. 2, pod red. Z. Radwańskiego, wyd. 2, Warszawa 2008.

Szpunar A., O konwalidacji nieważnej czynności prawnej, „Państwo i Prawo „1986, nr 5.

Szpunar A., O konwalidacji wadliwych czynności prawnych, „Państwo i Prawo” 2002, nr 7 .

The British Columbia Law Institute, Report on Relief Under Legally Defective Contracts: The Uniform Illegal Contracts Act, 2008, nr 52.

The Law Commission, Illegal Transactions: The Effect of Illegality on Contracts and Trusts, „Consultation Paper” 1999, nr 154.

The Law Commission, The Illegality Defence in Tort, „Consultation Paper” 2001, nr 160.

The Law Commission, The Illegality Defence, 2001, nr 320.

The Law Commission, The Illegality Defence, A Consultative Report, „Consultation Paper" 2009, nr 189.

Trzaskowski R., Skutki sprzeczności umów obligacyjnych z prawem. W poszukiwaniu sankcji skutecznych i proporcjonalnych, Warszawa 2013.

Turner Ch., Key Facts Key Cases, Contract Law, Abingdon 2014.

Ware S.J., Arbitration Law's Separability Doctrine After Buckeye Check Cashing, Inc. v. Cardegna, „Nevada Law Journal” 2007, vol. 8, nr 107.

Wincenciak M., Sankcje w prawie administracyjnym i procedura ich wymierzania, Warszawa 2008.

Więzowska B., Odpowiedzialność cywilna na zasadzie stuszności, Warszawa 2009.

Zimmermann R., The Law of Obligations, Roman Foundations of the Civilian Tradition, Oxford 1996. 


\section{STRESZCZENIE}

Artykuł ma na celu wprowadzenie do problematyki nieważności czynności prawnej w jurysdykcjach common law. W pierwszej części zostały zawarte uwagi wprowadzające dot. przyjętej metodologii i wskazane kryteria porównawcze do umiejscowienia w terminologii stosowanej w prawie polskim. Dla wyjaśnienia najważniejszych odrębności i trudności w powiązaniu nieważności w common law z podejściem prawa polskiego została pokrótce przedstawiona definicja stanu nieważności czynności prawnej i samej sankcji nieważności bezwzględnej.

Rozwiązania common law zostały omówione w zakresie terminologii i cech formalnych nieważności, głównych odmian sankcji nieważności, a także zostały przedstawione podstawowe przypadki zastosowania sankcji nieważności bezwzględnej lub sankcji najbardziej zbliżonych. Została dokonana ogólna charakterystyka sankcji void i voidable wraz z definicjami, które wyróżnia nauka lub opracowania typu restatement (np. prawo amerykańskie lub brytyjskie).

W ramach oceny najnowszych tendencji dotyczących poszukiwania zasad proporcjonalnego i nowoczesnego stosowania sankcji nieważności bezwzględnej, w artykule szczególną uwagę zwraca się na sankcję sędziowską (structured discretion) wypracowaną w trakcie rozwoju poglądów na temat cech normy sankcjonującej zwanej unenforceability, która jest co do zasady sankcją z tytułu nielegalności i niemoralności umowy.

Przedstawienie konstrukcji norm sankcjonującej nieważnością skutków prawnych z mocy prawa pociągało za sobą analizę skutków naruszenia ustawy w common law, sankcji ustawowej nielegalności oraz nielegalności na gruncie prawa powszechnego, sankcji ustawowej nielegalności (contracts illegal by statute, contracts rendered unenforceable by statute; statutory illegality), sankcji nielegalności na gruncie prawa powszechnego (contracts illegal at common law). Efekt nielegalności w zakresie egzekwowalności umowy oraz restitutio in integrum został omówiony $\mathrm{w}$ ramach wskazania cennych poglądów dotyczących konieczności poszukiwania proporcjonalności sankcji nieważności bezwzględnej. Zagadnienie to jest szczególnie istotne dla prawa polskiego wskutek zaproponowania sankcji sędziowskiej (structured discretion) w projekcie polskiego Kodeksu cywilnego z 2015 r.

Wpływ modelu sankcji sędziowskiej na prawo polskie został ukazany na tle omówienia prac nad reformami oceny stosowanej sankcji w projektach m.in. Wielkiej Brytanii. Prace te wraz z bardzo cennymi materiałami gromadzonymi w trakcie konsultacji tych prac miały także wpływ na kształt sankcji i jej proporcjonalizacji w opracowywaniu Common Frame of Reference. Przeanalizowano m.in. konieczność zwrócenia szczególnej uwagi na odejście od naturalistycznego postrzegania sankcji nieważności bezwzględnej na rzecz rezygnacji z dogmatów wypracowanych jeszcze w czasach tzw. wielkich kodyfikacji XIX w. Dorobek 
nauki prawa i judykatury common law pokazuje jednoznacznie, że lakoniczna terminologia $w$ normatywnych modelach sankcji nieważności bezwzględnej w kręgu ius civile wywarła bardzo negatywny wpływ na skuteczność i efektywność prawa. W kręgu anglosaskim przewaga podejścia procesowego mityguje największe problemy, z tego wynikające ryzyko. Dla systemów ius civile jedynym rozwiązaniem jest adaptacja sankcji sędziowskiej oraz przejście na konwencjonalne definiowanie zakresu pojęciowego terminologii dotyczącej systemu sankcji wadliwych czynności prawnych.

Słowa kluczowe: nieważność czynności prawnej, sankcja sędziowska, normy sprzężone, norma sankcjonująca, efekt nielegalności, model normatywny nieważności, sankcja nieważności bezwzględnej, Common Frame of Reference, skuteczność i efektywność prawa systemu sankcji wadliwych czynności prawnych 


\section{SUMMARY}

The article aims to introduce the concept of the invalidity of a juridical act in common law jurisdictions. The first part contains introductory remarks describing the adopted methodology and chosen comparative criteria to explain the terminology and notion applied. To explain the most important differences and difficulties in linking invalidity in common law with the Polish law approach, there was presented the definition of the so-called state of invalidity of the juridical act and the sanction of nullity.

Common law solutions have been discussed in terms of terminology and formal features of invalidity as a legal institution; the main types of the sanctions leading to invalidity, and also the basic cases of applying similar sanctions have been presented. The general characteristics of void and voidable contracts (sanctions) have been made, along with definitions proposed by jurisprudence or in the restatement of contract law (e.g., US or UK law).

As a part of the assessment in the article of the latest tendencies regarding the need for a proportional and modern application of sanction of invalidity, special attention was paid to the statutory structured discretion developed to search for a proper sanctioning norm called unenforceability. This is, in principle, a sanction for the illegality and immorality of a contract (or other legal juridical acts).

The operation of illegality in the law of obligations and its legal effects entailed an analysis of the effects of violating law in common law, especially: the statutory effects of illegality and illegality under common law and the effects of illegality in terms of whether the contract is rendered void or unenforceable or voidable by reason of the illegality.

As far as contract enforceability and restitutio in integrum is concerned, it has been discussed that in a few common law jurisdictions the legal rules should be replaced by a statutory structured discretion to seek the proportionality of such sanction. Briefly speaking, the traditional rules that the courts have developed was treated as plainly unsatisfactory and, if applied, as producing unacceptable results.

This issue is particularly important for Polish law as a result of proposing a statutory basis for the structured discretion in the draft Polish Civil Code in 2015.

The impact of such judge-made sanction in Polish law has been discussed in contrast to the background of the reforms of illegality in chosen common law countries. These efforts, together with valuable materials collected during the consultation process, also had an impact on the shape of the sanction and its proportionality in the Common Frame of Reference proposal on the invalidity of juridical acts. Final remarks in the context of Polish civil law and the normative 
model of the void juridical were shortened to the necessary minimum due to the size of the article. It was recommended, among others, to be necessary to make progress in regulating normative models of invalidity as a norm for sanctioning a juridical act by removing its legal effects. It is important to pay special attention to the resignation from the naturalist perception of such absolute sanction in private law for an active approach distant from the dogmas developed in the so-called the great codifications of the nineteenth century. The achievements in that field of civil law and common law jurisprudence clearly showed that the laconic terminology mostly used in the normative models of this sanction had a very negative impact on the effectiveness and efficiency of private law. In common law, the predominance of the precedent approach mitigates the greatest problems with this resulting risk; for ius civile legal systems, the only solution is the adaptation of the conventional definition and model of the sanctions for defective juridical acts.

Keywords: invalidity, a juridical acts, nullity of the juridical act, the sanction of nullity, invalidity, void and voidable contracts, structured discretion, illegality and immorality of the contract, the operation of illegality, unenforceable contracts, the law of restitution, enforceability, proportionality of sanction, draft Polish Civil Code in 2015, Common Frame of Reference, effectiveness and efficiency of the private law 